\title{
Valuing Student Speech: The Work of the Schools as Conceptual Development
}

\author{
Richard L. Roe
}

TABLE OF CONTENTS

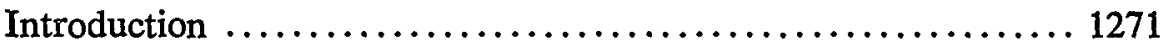

I. A View from the Court: The Work of the Schools as the Inculcation of Values .......................... 1276

A. Judicial Acknowledgment of Student Speech Rights ... 1277

B. The Court's Retreat from Protectimg Student Speech... 1280

II. A View from Educational Research: The Work of the Schools as Conceptual Development ................. 1292

A. The Conceptual-Development Model of Learning: Principles from Cognitive Research ................ 1293

1. Students' Existing Knowledge and Cognitive Structures Are Major Influences on Learning .......... 1294

2. Cognitive Structures Are Learner, Not School, Functions .............................. 1296

3. Expression Is Vital for Conceptual Development ... 1299

B. Conceptual Development Is the Schools' Acknowledged

Mission ...................................... 1301

1. Bloom's Taxonomy......................... 1301

2. State Curriculum Guides...................... 1304

C. Falling Short of Their Cogmitive Ideals: Why Schools

May Prefer the Inculcative Model over Conceptual

Development ................................. 1308

D. Conceptual Development Promotes Democratic

Education ................................... 1312

III. Implications of the Work of the Schools as Conceptual

Development: Expansive Student Freedom of Expression ... 1315

A. Freedom of Expression Is Necessary for Students'

Conceptual Development: The Cognitive Classroom ... 1316

1. The Value of Freedom of Expression in Schools ... 1316

2. The Conceptual Development Classroom ......... 1318

B. Student Speech That Diverges from the Prescribed

Curriculum Interferes Little with the Work of the

Schools ...................................... 1323 
C. Conceptual Development and Judicial Deference ..... 1330

D. The Appeal of Thomas F. O'Connor: A Case Study ... 1335

Conclusion ...................................... 1342 


\title{
Valuing Student Speech: The Work of the Schools as Conceptual Developinent
}

\author{
Richard L. Roe $\dagger$
}

\begin{abstract}
Student expression in precollege education deserves first amendment protection because of its essential educational value. Under the prevailing judicial understanding of precollege education's purpose as the inculcation of knowledge and values, school authorities can restrict student speech by claiming a rational relationship to a legitimate pedagogical objective. This understanding is incomplete. Recent advances in cognitive psychological research and learning theory reveal that the work of the schools is more appropriately understood as conceptual development, in which student expression plays a fundamental role in the growth of students' knowledge, intellect, and capacity for rational deliberation. While the schools themselves proclaim conceptual development as their work, they often fall short of this ideal in practice. Student speech that diverges from or contradicts the school's curricular message but does not interfere with or disrupt the school's work contributes to cognitive progress in learning. Therefore, courts should provide significantly greater protection than is currently available for student speech by adopting a first amendment analysis that values student speech more and defers less to the assertions of school authorities.
\end{abstract}

\section{INTRODUCTION}

Imagine the following scenario taking place in a school classroom. A history teacher asks her students, "What is George Washington famous for?" One student responds, "He was the first president of the United States," and after a pause adds, "and he owned slaves." Assume further that the school's intended curricular message, ${ }^{1}$ as represented im

$\dagger$ Professor of Law and Director of the Street Law Clinics, Georgetown University Law Center. A.B. 1969, Yale University; J.D. 1977, University of Maine School of Law. I would like to thank my colleagues Peter Byrne, Joseph Daly, James Feinerman, Michael Gottesman, Thomas Krattenmaker, David Nadvorney, Isidore Starr, and Judith Torney-Purta for their support and very helpful comments on earlier drafts. I would also hike to thank Alexander Fernández, Joy Goldbaum, Sheryl Goldstein Holtz, and David Millard for their outstanding research assistance.

1. It is important to distinguish at the outset between the school's curriculum and its curricular messages. When I refer to the school's curriculum, I mean "the knowledge, skills, and values of the educative experience that neet criteria of excellence that make them worthy of study." J. Novak \& D. Gowan, Learning How to LeARN 6 (1984). The curriculum encompasses the goais and objectives of learning as well as the strategies, methods, and materials utilized to achieve them. In contrast, curricular messages are the specific content of the lessons that the school intends to impart to its students. 
its textbook, is to identify George Washington as our nation's first president. The prescribed textbook does not mention that George Washington owned slaves. The teacher responds to the student's remarks by saying, "Yes, it's important to know that George Washington was our first president. But it is also true that he owned slaves. Let's assess George Washington's significance in light of his ownership of slaves among his other attributes and accomplishments."

What is the extent of school ${ }^{3}$ authorities' power to object to or restrict the student's contribution of the fact that Washington owned slaves? Is the student's right to make this remark defensible under either the Constitution or educational policy? How should the teacher have responded to the slave-ownership part of the student's answer? Should the teacher have "corrected" the student by reasserting the school's official lesson, as stated in its textbook? Should the teacher have ignored the student's comment? Could the school reprimand the teacher for promoting the view that Washington owned slaves? Could the school in any other way limit the student's expression regarding Washington's slave ownership? What are the constitutional and policy implications of the effect on students' civic development resulting from school programs that eitler encourage or discourage student speech diverging from the scliool's officially established curriculum?

How courts and education policymakers address these questions depends on their perception of the educational function of the schools, which is also known as "the work of the scloools." The first amendment is implicated when school authorities restrict or suppress speecl that they believe to be educationally inappropriate or incompatible with this work. ${ }^{5}$ However, the Supreme Court has recently granted schools broad

2. This fictional exchange draws on the facts of Board of Educ. v. Pico, 457 U.S. 853 (1982). Pico involved a challenge to a school board's decision to remove allegedly "offensive" and "antiAmerican" books from the school library. In providing an example of such an "anti-American" book, members of the school board cited A. Childress, A Hero Ain't Nothin' But A SANDWICH 43 (1973) for its reference to George Washington as a slaveholder. See Pico, 457 U.S. at 873 n.25. For a discussion of the Pico decision, see infra text accompanying notes 47-64.

3. In this Article the term "school" refers to precollege education-that is, elementary and secondary schools.

4. In determining whether student speech was compatible with or disruptive of the school's function, the Supreme Court has used the phrase "work of the schools" to describe the operations of public elementary and secondary schools. See Tinker v. Des Moines Indep. Community School Dist., 393 U.S. 503, 508 (1969). For a discussion of Tinker, see infra notes $29-45$ and accompanying text. Similarly, in Bethel School Dist. No. 403 v. Fraser, 478 U.S. 675, 685 (1986), the Court described the school's work as "the school's basic educational mission." For a discussion of Fraser, sec infra notes 65-83 and accompanying text.

5. See Garvey, Children and the First Amendment, 57 TEx. L. REv. 321, $326-27$ (1979) (educational practices that prevent children from attaining the knowledge and intellectual skills necessary for effective exercise of their first amendment rights abridgc their rights); see also Wright, Free Speech Values, Public Schools, and the Role of Judicial Deference, 22 NEW ENG. L. REV. 59, 61 (1987) (public school child has "a presently enforceable free speech right prohibiting restrictions 
powers to limit student speech otherwise protected by the first amendment when such speech interferes with the schools' educational function. ${ }^{6}$ School authorities can, according to their view of the work of the schools, restrict student speech to shape educational practices, but such restrictions may retard students' development of the knowledge and skills fundamental to personal growth and to effective political, economic, and social participation in society. The interaction between the schools' curriculum and student expression in American precollege education has been characterized by tension between polar views of the function of schools: ${ }^{7}$ one to sociahze young people in the ideas and values deemed essential to enable them to participate in our democratic society ("inculcation of values"8), the other to expose young people to a variety

imposed by the school in such a way as to significantly impair, inhibit, or otherwise 'stunt' the development of the student's future free speech-relevant capacities").

6. See, e.g., Hazelwood School Dist. v. Kuhlmeier, 484 U.S. 260, 273 (1988) (school can censor student-written articles in high school newspaper if such action is reasonably related to legitimate pedagogical concerns). This practice of deferring to school board decisions that are "reasonable" has been followed by at least one appellate court, see Searcey v. Harris, 888 F.2d 1314, 1321 (11th Cir. 1989) (school can limit speaker access to "Carecr Day" program if limits are reasonable), and has been used in the school context in areas other than student speech, see, e.g., Perry Educ. Ass'n v. Perry Local Educators' Ass'n, 460 U.S. 37, 49 \& n.9 (1983) (school district can impose content-based restrictions limiting aceess to teacher mailboxes if such restrictions are reasonable in light of the intended purpose of maintaining the mailboxes rather than merely an effort to suppress views).

7. See Buss, School Newspapers, Public Forum, and the First Amendment, 74 Iowa L. Rev. 505, 505-06 (1989); see also Ingber, Socialization, Indoctrination, or the "Pall of Orthodoxy": Value Training in the Public Schools, 1987 U. 1LL. L. REv. 15, 15-20 "'first amendment paradox" of public education that must socialize children in society's norms while promoting children's autonomy to modify or abandon those norms); Levin, Educating Youth for Citizenship: The Conflict Between Authority and Individual Rights in the Public School, 95 Y ALE L.J. 1647, 1649 (1986) ("Socialization to values through a uniform educational experience necessarily conflicts with freedom of choice and the diversity of a pluralistic society.").

Commentators from the voluminous literature in this area fall into three eategories: (1) those stressing the state's prerogative to indoctrinate, (2) those stressing the students' right to be free from indoctrination, and (3) those stressing the tension and balance between the inculcation of values and a free marketplace of ideas. Buss, supra, at 506 n.4. See also T. van GeEL, THE CouRTS AND AMERICAN Education LAw 167 (1987); Note, Education and the Court: The Supreme Court's Educational Ideology, 40 VAND. L. REV. 939, 942-49 (1987) (authored by William Senhauser) (need to identify three streams of educational ideology-cultural transmission, romanticism, and progressivisin-before analyzing and assessing the influence of these ideologies in student speech cases).

8. "Inculcation" describes the schools' authority to select and implement their curriculuin by “'provid[ing] educational experiences that give pupils an understanding of the values, mores, and traditions of society, and that will ensure adherence to these values in behavior." "Freeman, The Supreme Court and First Amendment Rights of Students in the Public School Classroom: A Proposed Model of Analysis, 12 Hastings Const. L.Q. 1, 2 n.1 (1984) (alteration in original) (emphasis added) (quoting J. SAYlor \& W. AleXander, CURRICUlum PlanNing FOR MODERN Schools 127 (1966)); see also Goldstein, The Asserted Constitutional Right of Public School Teachers to Determine What They Teach, 124 U. PA. L. REv. 1293, 1350 (1976) ("historically accepted societal view [is] that the deliberate inculcation of the right societal values is a major function of American public education"); Goldstein, Reflections on Developing Trends in the Law of Student Rights, $118 \mathrm{U}$. PA. L. REV. 612, 614 (1970) (traditional view of precollege education is the inculcative or "the 
of ideas and values that they learn and evaluate on the basis of their own developing knowledge, experience, and judgment ("marketplace of ideas"9).

The Supreme Court currently views the work of the schools to be the inculcation of values. ${ }^{10}$ For example, in Hazelwood School District $v$. Kuhlmeier ${ }^{11}$ the Court imphicitly relied on inculcative pedagogical notions when it ruled that the restriction of expression in school-sponsored activities by school authorities does not violate the first amendment provided the authorities' actions are "reasonably related to legitimate pedagogical concerns."12 The Kuhlmeier Court arguably expanded the notion of inculcation from a prescriptive sense, in which the school selectively offers knowledge and skills to students, to an exclusive sense, in which the school limits information that may contradict the ideas it prescribes $^{13}$-im other words, the Court broadened the school's authority to select ideas for the curriculum also to encompass the power to exclude ideas from the school. Thus, although the Court had proclaimed in an

prescriptive model, [in which] information and accepted truths are furnished to a theoretically passive, absorbent student. The teacher's role is to convey these truths rather than to create new wisdoin."); Stewart, The First Amendment, The Public Schools, and the Inculcation of Community Values, 18 J.L. \& EDUC. 23, 23-29 (1989) ("[E]ducation must inevitably be inculcative, in the sense that it will dispose students to accept some values and opinions and reject others," id. at 25 , and therefore "school authorities should be given very broad powers to structure educational programs with a view towards inculcating community values," id. at 28.). The inculcation model presumes a school's power to control student learning, a presumption that is contradicted by contemporary learning theory. See infra notes $145-64$ and accompanying text.

9. The "inarketplace of ideas," a forum in which a wide range of ideas are expressed and exchanged freely, is a familiar and much debated concept in first amendment analysis and edueation theory. See Buss, supra note 7, at 505 \& n.2; see also Levin, supra note 7, at 1649 (contrasting "[s]ocialization to values through a uniform educational experience with freedon of choice and the diversity of a pluralistic society"); Mitchell, Secularism in Public Education: The Constitutional Issues, 67 B.U.L. REV. 603, 700 (1987) ("[u]nder the Marketplace inodel . . p public schools present to students a variety of viewpoints so that each student may develop his or her own, frec of government's prepossessing"); Nahnod, Controversy in the Classroom: The High School Teacher and Freedom of Expression, 39 GEo. WASH. L. REV. 1032, 1055 (1971) ("student interest in learning, and thus in access to classroom discussion of controversial subjects"); infra note 257 and accompanying text (distinguishing the marketplace and conccptual-developinent models).

10. See Bethel School Dist. No. 403 v. Fraser, 478 U.S. 675, 681 (1986) (objective of public education is to inculcate fundamental values necessary to maintain a democracy, and first amendment values must be balanced against society's interest in tcaching students socially appropriate behavior); see also van Geel, The Search for Constitutional Limits on Governmental Authority to Inculcate Youth, 62 TEx. L. REv. 197, 239 (1983) (arguing that in Board of Educ. v. Pico, 487 U.S. 853 (1982), "at least eight Justices agreed that school boards may engage in the inculcation of youth" and "simply assumed without analysis that this objective was to be given considerable weight").

11. 484 U.S. 260 (1988).

12. Id. at 273.

13. The Court affirmed the power of schools to limit contradiction because schools "rctain the authority to refuse to sponsor student speech that might reasonably be perceived to advocate . . . conduct . . . inconsistent with 'the shared values of a civilized social order.' "Id. at 272 (quoting Bethel School Dist. No. 403 v. Fraser, 478 U.S. 675, 683 (1986)). 
earlier opinion that students have an "undoubted freedom to advocate unpopular and controversial views in schools and classrooms," 14 the practical effect of the judicial deference to school officials expressed in Kuhlmeier leaves little real protection for student expression not approved by school authorities. ${ }^{15}$

The notion of the school as a marketplace of ideas has been largely unpersuasive in the area of student expression, and courts have generally limited its application to postsecondary education. ${ }^{16}$ The marketplace model allows students to exercise their constitutional freedoms, a practice that necessarily restrains the state from imposing its official dogma. But such restramt on the power of school authorities does not comport with the Court's current willingness to grant schools power to restrict student expression. ${ }^{17}$

This Article argues that neither the inculcation nor marketplace model appropriately describes the work of the schools. Rather, educational pohicy and constitutional rules would be more properly fashioned according to an alternative "conceptual-development" model. ${ }^{18}$ This model views the educational mission of schools to be development of students' knowledge in conjunction with their cognitive capacities. The notion of conceptual development draws from both the imculcation and marketplace models as well as from longstanding educational practice, democratic educational theory, and recent developments in cognitive psychology.

14. Bethel School Dist. No. 403 v. Fraser, 478 U.S. 675,681 (1986).

15. See Krizek v. Board of Educ., 713 F. Supp. 1131, 1139 (N.D. Il1. 1989) (broadly applying the Kuhlmeier standard to uphold restrictions on the content of classroom materials).

16. See, e.g., Bender v. Williamsport Area School Dist., 741 F.2d 538, 547-49 (3d Cir. 1984) (although colleges may be marketplaces of ideas and hence open forums for their students, high school expression is more circumscribed), vacated, 475 U.S. 534 (1986) (lack of standing); see also Goldstein, supra note 8, at 1341-43 (marketplace-of-ideas paradigm generally pertains to higher education, while value inculcation has traditionally been viewed as the role of precollcge education). The most recent Supreme Court eases have ignored marketplace rationales. See, e.g., Hazelwood School Dist. v. Kuhlmeier, 484 U.S. 260 (1988); Bethel School Dist. No. 403 v. Fraser, 478 U.S. 675 (1986). However, commentators have argued that the interchange of ideas associated with the marketplace model is essential to foster precollege students' future civic competence. See, e.g., Ingber, supra note 7, at 25, 30 (arguments for developing "personal autonomy" during precollege education); Keiter, Judicial Review of Student First Amendment Claims: Assessing the LegitimacyCompetency Debate, 50 Mo. L. REv. 25, 48-55 (1985) (advocating multidimensional model that encompasses both marketplace and inculcative approaches to education). For a general discussion of the marketplace theory, see Ingber, The Marketplace of Ideas: $A$ Legitimizing Myth, 1984 DUKE L.J. 1.

17. See supra notes 10-15 and accompanying text.

18. I use the term "conceptual development" to mean the acquisition and utilization of knowledge in conjunction with the acquisition and use of cognitive skills. It describes the process by which one develops the ability to relate new information to one's existing knowledge base and cognitive structures, to modify one's cognitive structures and knowledge in light of new information, and to recall or access this knowledge and apply it to subsequent situations. See infra notes 127-72 and accompanying text (discussing the work of the schools as conceptual development). 
I begin by showing as mistaken the Supreme Court's current belief that precollege education focuses primarily on the inculcation of values. This belief only partially describes the work of the schools. ${ }^{19}$ Part I examines recent Supreme Court opinions on school speech, demonstrating that the Court views the work of the schools as inculcative. Part II shows that conceptual development, rather than inculcation or the marketplace of ideas, better describes the work of the schools. Conceptual development is more in accord with recent advances in cognitive science, ${ }^{20}$ the learning goals that schools actually set for theniselves, and the basic tenets of democratic educational philosophy. Part III argues that an understanding of the work of the schools as conceptual development necessitates a high degree of tolerance for student speech under the protection of the first amendment. Finally, I conclude with a recomniended approach to analyzing student free-speech cases.

\section{I}

\section{A View FROM THE COURT: THE WORK OF THE SCHOOLS} AS THE INCULCATION OF VALUES

An inherent conflict between the authority of the state to instill knowledge and values it deems important and the speech interests of individual students characterizes Supreme Court jurisprudence in the area of school speech. ${ }^{21}$ This conflict has historically been reconciled in favor of the state's inculcative interests-courts, legal commentators, and educators alike agree that one of the functions of schools is to impart school-determined and school-endorsed knowledge, skills, and values to students. ${ }^{22}$ Recent Supreme Court jurisprudence in the area of school speech has echoed such inculcative views, ${ }^{23}$ recognizing the schools'

19. This point has not gone unrecognized. See Hazelwood School Dist. v. Kuhlmeier, 484 U.S. 260, 280 (1988) (Brennan, J., dissenting) ("public educators must accommodate some student expression even if it offends them or offers views or values that contradict those the school wishes to inculcate"); J. SAYLOR \& W. ALEXANDER, CURRICULUM PIANNING FOR MODERN SCHOOLS 12627 (1966) (inculcation of values is only one of eight categories of functions that schools serve); Buss, supra note 7, at 507-09 (many aspects of the American school system limit the schools' power to impose views on students).

20. The relatively new field of cognitive science is "a federation of older disciplinespsychology, linguistics, computer science-all concerned with aspects of human mental functioning. Cognitive science offers a reconceptualization of the nature of the learning process and new approaches to the investigation of learning." Glaser, Cognitive Scicnce and Education, 40 INT'L Soc. ScI. J. 21, 21 (1988).

21. See supra note 7 and accompanying text.

22. See, e.g., J. SAYLOR \& W. AleXANDER, supra note 19; M. YUdOF, D. KIRP, T. VAN GeEL. \& B. Levin, KIRP \& Yudof's Educational Policy aNd THE LAw 145 (2d ed. 1984); Goldstein, supra note 8 , at 1343 .

23. See, e.g., Board of Educ. v. Pico, 454 U.S. 853, 864 (1982) ("school boards must be permitted 'to establish and apply their curriculum in such a way as to transmit community values,' and ... 'there is a legitimate and substantial community interest in promoting respect for authority and traditional values be they social, moral, or political" (quoting Bricf for Petitioners at 10)); 
authority to select and implement their curricula in furtherance of their educational mission. ${ }^{24}$

Student speech rights are often viewed as weak despite the primacy of first amendment values. Freedom of speech for children simply has not been accorded the same weight as it has for adults. The rationale for this disparity is based on the supposed incompetence of children, arising from their physical, mental, and emotional immaturity. ${ }^{25}$ Some cominentators argue that because of this incoinpetence and immaturity, children are not as capable of utilizmg their first amendment rights as are adults. ${ }^{26}$ This inability to adequately exercise their rights is said to diminish the value of children's freedom of speech both to the children themselves and to society at large. ${ }^{27}$ Furthermore, the immaturity of children is thought to make them more vulnerable to perceived negative influences that the state as well as parents may want to control through the curricular authority vested in the state as educator. ${ }^{28}$

\section{A. Judicial Acknowledgment of Student Speech Rights}

In the seminal case of Tinker $v$. Des Moines Independent Community School District ${ }^{29}$ the Supreme Court appeared to articulate a rule that required tolerance of student speech rights. School authorities had prohibited students from wearing black armbands at school to protest the Vietnam War. ${ }^{30}$ The antiwar position was highly unpopular at that time,

Ambach v. Norwick, 441 U.S. 68, 77 (1979) (schools' functions include "inculcating fundamental values necessary to the maintenance of a democratic political system"); Tinker v. Des Moines Indep. Community School Dist., 393 U.S. 503, 507 (1969) ("Court has repeatedly emphasized the need for affirming the comprehensive authority of the States and of school officials . . . to prescribe and control conduct in the schools"); Brown v. Board of Educ., 347 U.S. 483, 493 (1954) ("[education] is the very foundation of good citizenship").

24. The extreme nature of the actions of school authorities necessary before the Court will strike them down demonstrates the broad latitude granted to school decisions regarding the curriculum. See, e.g., Board of Educ. v. Pico, 457 U.S. 853 (1982) (unconstitutional for school board to remove books from school library merely because board views them as offensive); Tinker v. Des Moines Indep. Community School Dist., 393 U.S. 503 (1969) (unconstitutional for school to prohibit students' wearing of armbands in protest of Vietnam War); West Va. State Bd. of Educ. v. Barnette, 319 U.S. 624 (1943) (unconstitutional for public schools to compel salute and pledge of allegiance to American flag); Pierce v. Soc'y of Sisters, 268 U.S. 510 (1925) (unconstitutional for Oregon to require public education for all children between ages of eight and sixteen); Meyer v. Nebraska, 262 U.S. 390 (1923) (unconstitutional for state to forbid teaching of foreign languages in schools).

25. See Garvey, supra note 5, at 323; Ingber, supra note 7, at 18.

26. See Garvey, supra note 5, at 338-49 (criticizing three justifications often advanced for giving children first amendment speech rights equal to those of adults); Goldstein, supra note 8, at 1343-44 (contrasting differences in choice and maturity between high school and college students).

27. See Garvey, supra note 5, at 339-40.

28. See Ingber, supra note 7, at 32-40 (discussing competing claims of different groups over the authority to control the curriculum).

29. 393 U.S. 503 (1969).

30. The majority considered it significant that students in Des Moines schools had not been prohibited from wearing other "symbols of political or controversial significance." Id. at 510 . 
and school officials feared that the armbands would create a disturbance. ${ }^{31}$ Therefore, several students who wore armbands to school were suspended, ${ }^{32}$ although hittle if any disturbance occurred. ${ }^{33}$ In holding that the students' first amendment rights had been violated, the Tinker Court announced the principle that pubhic school students do not "shed their constitutional rights to freedom of speech or expression at the schoolhouse gate."34

Despite this seemingly broad acknowledgment of student freedomof-speech rights, the test actually developed by the Tinker Court afforded quite narrow protection. The Court explicitly recognized the conflict between student speech rights and the authority of schools to restrict such rights. ${ }^{35}$ In reconciling the inculcative function of the schools with the free-speech rights of students, the Court mandated protection of student speech that school authorities could not show to "materially and substantially mterfere" with the work of the school, school discipline, or the rights of others in the school commumity. ${ }^{36}$ Thus, in addressing the conflict, the Court struck a balance that required himited tolerance of student speech rights.

While the Tinker Court developed a standard for judging student speech that interferes with the work of the schools, it did not address speech that merely diverges from the school's instructional message. Thus, it remained unclear after Tinker whether and to what degree school officials must afford substantial tolerance for divergent student expression. ${ }^{37}$ The Tinker majority's understanding of the work of the

School authorities clearly had "singled out for prohibition ... [the] expression of one particular opinion." Id. at 511 .

31. Id. at 508.

32. Id. at 504.

33. The majority opinion stated that "the record does not demonstrate any facts which might reasonably have led school authorities to forecast substantial disruption of or material interference with school activities, and no disturbances or disorders on the school premises in fact occurred." Id. at 514. But see id. at 519 (Black, J., dissenting) (harsh words and distractions brought about by students wearing armbands).

34. Id. at 506.

35. After establishing the proposition that students retain some first amendment speech rights in school, the Court added:

On the other hand, the Court has repeatedly emphasized the need for affirming the comprehensive authority of the States and of school officials ... to prescribe and control conduct in the schools. Our problem lies in the area where students in the exereise of First Amendment rights collide with the rules of the school authorities.

Id. at 507 (emphasis added) (citations omitted).

36. Id. at 508-09, 513. The Court implicitly recognized the inculcative role of schools when it adopted the "material and substantial interference" standard. Under it, when student expression interferes with the work of the schools, the work of the schools prevails. If student speech falls short of material and substantial interference, however, the speech is protected. Another way of describing the operation of the Tinker standard is that the schools' messages must always reach the students. See Buss, supra note 7, at 516-17.

37. The question of whether school authorities can prevent divergent student expression from 
schools appears to support the proposition that students may express views contrary to, and thus divergent from, those endorsed by the school. Applying first amendment rights "in light of the special characteristics of the school environment,"38 the Court adhered to the view that the work of the schools must be open to an exchange of ideas, mcluding sentiments that are not officially sanctioned. ${ }^{39}$ The Court recognized student freedom of expression to be a constitutionally protected right: "In our system, state-operated schools may not be enclaves of totalitarianism. . . . [S]tudents may not be regarded as closed-circuit recipients of only that which the State chooses to commumicate."40 The Tinker Court's respect for a diversity of viewpoints within the school ${ }^{41}$ is in accord with the conceptual-development view of schooling, ${ }^{42}$ which embraces rather than suppresses divergent student speech.

The Tinker majority rejected the inculcative position articulated by Justice Black in dissent, which sought to deny student first amendment rights in the face of conflicting opinions of school authorities. According to Black, no one has an absolute right to speak-that right is always conditioned on the coinpatibility of speech with the forum or context in which it occurs. ${ }^{43} \mathrm{He}$ argued that the right of students to speak in schools was limited because student speech tliat diverged from what the school authorities imtended to teach threatened the school authorities'

reaching the teacher or other students under the Tinker standard depends on the understanding of the function of the schools. If the schools' work is seen as exclusively inculcative, the threshold for material and substantial interference with it would be low-inculcative education is relatively intolerant of dissent and contradiction. On the other hand, if the schools' work is perceived as cognitive, views alternative and contradictory to those of the schools would be less of an interference-the threshold for material and substantial imterference would be higher and more divergent student speech would be tolerated. For a discussion of the impact of how the courts characterize the schools' work on the courts' tolerance for divergent student speech, see infra notes 274-79 and accompanying text.

38. Tinker, 393 U.S. at 506.

39. Id. at 511 .

40. Id.

41. This deference to diversity within the schools is acknowledged by a long line of education cases. See, e.g., Keyishian v. Board of Regents, 385 U.S. 589 (1967) (striking down state statutes and regulations barring subversives from teaching at the university level); Sweezy v. New Hampshire, 354 U.S. 234 (1957) (holding that the contempt conviction of a college professor for refusal to answer questions regarding his lectures and his knowledge of certain political organizations was an invasion of the professor's liberties in the areas of academic freedom and political expression); Wieman v. Updegraff, 344 U.S. 183 (1952) (holding that the state cannot force teachers to take loyalty oaths regarding affiliation with "Communist front" organizations); cases cited supra note 24.

42. See supra note 18 (defining the conceptual-development model of the work of the schools).

43. Black stated:

While I have always believed that under the First and Fourteenth Amendments neither the State nor the Federal Government has any authority to regulate or censor the content of speech, I have never believed that any person has a right to give speeches or engage in demonstrations where he pleases and when he pleases.

Tinker, 393 U.S. at 517 (Black, J., dissenting). 
control. ${ }^{44}$ Furthermore, he believed that student expression of ideas not established in the curriculum was incompatible with the work of the schools, and he did not recognize that students' expressions of their views were valid or could make a valuable contribution in the schools. ${ }^{45}$

\section{B. The Court's Retreat from Protecting Student Speech}

Despite support in Tinker for a diversity of viewpoints within the school, the Supreme Court subsequently was less willing to uphold student free-speech claims when the conduct at issue more closely involved the school's authority over its curriculum. ${ }^{46}$ In Board of Education $v$. Pico ${ }^{47}$ the Court considered whether removal of books listed by a politically conservative organization as "objectionable" 48 from junior and senior high school hibraries was a matter concerning selection of the school's curriculum. The school board grounded its authority for the removal in its perceived duty to protect children from the "moral danger" presented by the books. ${ }^{49}$ However, a group of students claimed that the decision was based on board members' social, political, and moral views rather than on the books' educational suitability. Therefore, the students concluded that removal violated their first amendment rights..$^{50}$

The Pico Court focused its analysis on the school board's actions to determine if they were motivated by curricular concerns. If the removal of library books was a proper curricular decision induced by the school board's desire to limit the library's looldings to educationally suitable material, the school board had appropriately exercised its authority to

44. Black was concerned with the question of power in the schools: "I wish, therefore, wholly to disclaim any purpose on my part to hold that the Federal Constitution compels the teachers, parents, and elected school officials to surrender control of the American public school system to public school students." Id. at 526 (Black, J., dissenting).

45. Rejecting the value and worth of student speech, Black focused on the conventional notion of subordination of the young to the perceived superiority of their elders:

The original idea of schools, which I do not believe is yet abandoned as worthless or out of date, was that children had not yet reached the point of experience and wisdom which enabled them to teach all of their elders. ... [O]ne may, I hope, be permitted to harbor the thought that taxpayers send children to school on the premise that at their age they necd to learn, not teach.

Id. at 522 (Black, J., dissenting).

46. In Tinker the Court did not characterize the wearing of armbands in protest of the Vietnam War as a curriculum-related matter. There was no evidence that the school claimed any curricular interest in viewpoints about the Vietnam War. The Court found it "revealing" that school authorities had dissuaded a student from writing an article about the Vietnam War, but whether the article would have opposed or supported the war was not indicated in the opinion. Tinker, 393 U.S. at 510. In any event, Tinker does not rely on the school's articulated curricular position on the var, but rather on the school authorities' exclusion of a particular viewpoint.

47. 457 U.S. 853 (1982).

48. Id. at 856 .

49. Id. at 857 .

50. Id. at 858-59. 
determine the school's message. If, however, the removal was motivated by noncurricular concerns-in this case, the students' claim that the board's suppression of ideas was motivated solely by a desire to censor a particular viewpoint-then the school board abused its discretion in violation of the students' constitutional rights. ${ }^{51}$ The case was remanded to the trial court to determine the board's true motivation. ${ }^{52}$

The plurality and the dissent differed in their views of the extent of the board's power to inculcate fundamental values. The plurality acknowledged the authority of school officials in curricular matters and recognized the important role of public schools in the inculcation of the fundamental values necessary for preparing students to participate in our democratic society. ${ }^{53}$ As inculcators of values, school boards must be permitted wide discretion, enabling them to establish a curriculum that effectively conveys such values. ${ }^{54}$ However, this legitimate curricular function was restricted to cases in which the school board did not exercise its power "in a narrowly partisan or pohtical manner." M5 Moreover, the plurahty focused on "the special characteristics of the school library" as a place where students should be able to inquire into subjects beyond the school's curriculum ${ }^{56}$ and rejected the board's "claim of absolute discretion beyond the coinpulsory environment of the classroom, into the school library and the regime of voluntary inquiry that there holds sway." 57

The dissenters in Pico believed that the authority delegated to local boards of education to determine matters of curriculum, and the corresponding power to inculcate desired ideas and values, provided the board with broader discretion. The selection of library books was within the board's control because school libraries were a component of the school curriculum rather than a forum for unrestricted student speech. ${ }^{58}$ The availability of books in the school hibrary was a curricular function in that the books constituted a component of the school's chosen lesson

51. See id. at 870-71. Under the principle that "[o]ur Constitution does not permit the official suppression of ideas," the three-justice plurality established the following standard: "If [the board] intended by their removal decision to deny [the students] access to ideas with which [the board] disagreed, and if this intent was the decisive factor in [the board's] decision, then [board members] have exercised their discretion in violation of the Constitution." Id. at 871 (citations omitted).

52. Id. at 875 .

53. "[T]here is a legitimate and substantial community interest in promoting respect for authority and traditional values be they social, moral, or political." "Id. at 864 (quoting Brief for Petitioners at 10).

54. Id.

55. Id. at 870 .

56. Id. at 868 .

57. Id. at 869 .

58. "Unlike university or public libraries, elementary and secondary school libraries are not designed for freewheeling inquiry; they are tailored, as the public school curriculum is tailored, to the teaching of basic skills and ideas." Id. at 915 (Rehnquist, J., dissenting). 
and, thus, were endorsed by the school. ${ }^{59}$ Because school authorities sanction the materials in both the curriculum and the school library, the school should be considered to have approved of any language or ideas found therein. ${ }^{60}$

Furthermore, Justice Rehnquist rejected both the students' "right to receive ideas" and their corresponding speech interests, which were advocated by the plurahity. ${ }^{61}$ In his dissenting opinion, he explained his rationale in inculcative terms:

The idea that such students have a right of access, in the school, to information other than that thought by their educators to be necessary is contrary to the very nature of an inculcative education.

Education consists of the selective presentation and explanation of ideas. ...

$\ldots$

. . [E]lementary and secondary schools are inculcative in nature. . . . [T] The First Amendment right to receive information simply has no application to the one public institution which, by its very nature, is a place for the selective conveyance of ideas. ${ }^{62}$

The breadth of authority granted to schools to suppress views under this "right of access" approach marked a point of conflict within the dissent. Chief Justice Burger emphasized that the school board's actions in removing library books had not suppressed student expression of ideas. ${ }^{63}$ However, Justice Rehnquist would have gone further to broaden the school's authority to determine the content of its own curricular message, or speech by the school: he would have extended school authority to include the power to reach expression in the school. ${ }^{64}$ Thus, Justice Rehnquist evidently would have allowed the school to restrict student expression of ideas-speech in the school-that the board determined to be educationally inappropriate.

The two most recent Supreme Court decisions involving student speech rights may have further restricted Tinker's tolerance for speech in schools. Under a standard first developed by the Court in Bethel School

59. See id. at 889-93 (Burger, C.J., dissenting).

60. "Presumably all activity within a primary or secondary school involves the conveyance of information and at least an implied approval of the worth of that information." Id. at 889 (Burger, C.J., dissenting).

61. See id. at 866-69 (plurality's discussion of importance of student speech rights).

62. Id. at 914-15 (Rehnquist, J., dissenting); see also id. at 910-13 (Rehnquist, J., dissenting) (distinguishing student interests in receiving information in Pico from interests at issue in Court's prior holdings).

63. See id. at 886 (Burger, C.J., dissenting) (restraints were not placed on students, either in expression of their views or on their access to material in public libraries and bookstores).

64. See id. at 920 (Rehnquist, J., dissenting) ("school board may properly determine in many cases that a particular book, a particular course, or even a particular area of knowledge is not educationally suitable for inclusion within the body of knowledge which the school seeks to impart"). 
District No. 403 v. Fraser ${ }^{65}$ and later articulated in Hazelwood School District v. Kuhlmeier, ${ }^{66}$ school authorities have greater discretion to limit student speech that interferes with the school's intended curriculum than they did under Tinker's material and substantial interference test. Fraser and Kuhlmeier allow school authorities to restrict student speech if it takes place as a school-sponsored activity and the restriction is reasonably related to a legitimate pedagogical objective. ${ }^{67}$

In Fraser the Court understood the work of the schools as inculcation $^{68}$ when it deferred to the school's decision to suppress student speech believed to be incompatible with the school's curricular message. The subject of suppression was a nominating speech delivered by Matthew Fraser, a high school student, during a school-sponsored assembly in connection with student-government elections. The Court found Fraser's speech, which made repeated reference to his candidate in terms of exphicit sexual metaphors, ${ }^{69}$ so offensive as to be fundamentally incompatible with the school's educational mission:

The First Amendment does not prevent the school officials from determining that to permit a vulgar and lewd speech such as respondent's would undermine the school's basic educational mission. . . . [ []t was perfectly appropriate for the school to disassociate itself to make the point to the pupils that vulgar speech and lewd conduct is wholly inconsistent with the "fundamental values" of public school education. ${ }^{70}$

Despite announcing a standard that balanced freedom of speech in the classroom against society's interest in teaching appropriate behav-

65. 478 U.S. 675 (1986).

66. 484 U.S. 260 (1988).

67. Id. at 273; see also Fraser, 478 U.S. at $685-86$ (school authorities acted within their discretion to protect school's educational mission by sanctioning vulgar student speech in a school assembly).

68. " "P P]ublic education must prepare pupils for citizenship in the Republic. ... It must inculcate the habits and manners of civility as values in themselves conducive to happiness and as indispensable to the practice of self-government in the community and the nation." "Fraser, 478 U.S. at 681 (alteration in original) (quoting C. BEARD \& M. BEARD, NEw BASIC History of THE UNITED STATES 228 (1968)). "The inculcation of these values is truly the 'work of the schools." " Id. at 683 (quoting Tinker v. Des Moines Indep. Community School Dist., 393 U.S. 503, 508 (1969)).

69. The speech was:

"'I know a man who is firm-he's firm in his pants, he's firm in his shirt, his character is firm-but most ... of all, his belief in you, the students of Bethel, is firm.

" 'Jeff Kuhlman is a man who takes his point and pounds it in. If necessary, he'll take an issue and nail it to the wall. He doesn't attack things in spurts-he drives hard, pushing and pushing until finally-he succeeds.

"'Jeff is a man who will go to the very end-even the climax, for cach and every one of you.

" 'So vote for Jeff for A.S.B. vice-president-he'll never come between you and the best our high school can be." "

Fraser, 478 U.S. at 687 (Brennan, J., concurring) (alteration in original) (quoting Brief for Appellant at 47 ).

70. Id. at $685-86$ (emphasis added). 
ior, ${ }^{71}$ the Court deferred to the school's choice between the two values. ${ }^{72}$ The school serves as instructor of "essential lessons of civil, mature conduct" ${ }^{\text {73 }}$ and therefore can suppress speech that is offensive to such lessons. Furthermore, the Court noted that the educational process is not confined to books-younger students learn appropriate forms of discourse and expression from teachers and older students. ${ }^{74}$ Because "schools must teach by example," "75 and older students are the examples, the Court appeared to permit school authorities to require that student expression conform to the schools' specified curricular values. ${ }^{76}$

Instead of applying Tinker's material and substantial interference standard, the Fraser Court distimguished Tinker on several grounds. First, the armbands in Tinker expressed personal political beliefs that did not contradict any identified educational mission of the school, whereas the lewd speech in Fraser interfered with the school's mission of inculcating " "habits and mamiers of civility." "77 Second, the Tinker armbands were passive and nonintrusive, ${ }^{78}$ whereas Fraser's speech was active and offensive to some students ${ }^{79}$ and caused distraction from class work. ${ }^{80}$ Third, the Court found a "marked distinction" between the obscene sexual content of Fraser's speech and the students' conveyance of a political message through their armbands in Tinker. ${ }^{81}$

The reasoning in Fraser left little room for freedom of student speecl. Emphasis on the importance of inculcating values of civility

71. "The undoubted freedom to advocate unpopular and controversial views in schools and classrooms must be balanced against the society's countervailing interest in teaching students the boundaries of socially appropriate behavior." Id. at 681 .

72. "The determination of what manner of speech in the classroom or in school assembly is inappropriate properly rests with the school board." Id. at 683.

73. Id.

74. Id.

75. Id.

76. However, there are limits both to permissible values the schools may specify, see, e.g., Epperson v. Arkansas, 393 U.S. 97, 106 (1968) (establishment clause forbids state curricular goals that aid or oppose any religion), and to the degree students must conform to specified values, 'see, e.g., West Va. State Bd. of Educ. v. Barnette, 319 U.S. 624 (1943) (despite acknowledged authority to teach patriotic values, state cannot require swearing of allegiance to the flag).

77. Fraser, 478 U.S. at 681 (quoting C. BEARD \& M. BEARD, NEW BASIC HisTORY OF THE UNITED STATES 228 (1968)).

78. Id. at 680 .

79. Id. at 678 (students were bewildered and embarrassed), 683-84 (students were bewildered and could have been emotionally damaged).

80. Id. (teacher had to modify class presentation to discuss Fraser's speech). Rather than serve as a means for distinguishing Tinker - thereby avoiding the need to apply its rule-this view of the facts could be characterized as an application of the Tinker standard to a material and substantial interference with the school's work. The difficulty is that there was little evidence of disruption: "the School District failed to demonstrate that respondent's remarks were indeed disruptive. ... [W] [Were speech is involved, we may not unquestioningly accept a teacher's or administrator's assertion that certain pure speech interfered with education." Id. at 690 (Marshall, J., dissenting) (citations omitted); see also supra note 33 .

81. Fraser, 478 U.S. at 680. 
together with deference to the schools' determination of the form and content of those values left scant protection for the "undoubted freedom" to express divergent views in schools that the Court purported to recognize. ${ }^{82}$ Rather, the Court appeared ready and willing to defer to school authorities, particularly in situations in which the educational objective was viewed as the inculcation of values. ${ }^{83}$

In Hazelwood School District v. Kuhlmeier ${ }^{84}$ the Court moved further along the path opened by Fraser, deferring to the judgment of school authorities who had censored student speech. A high school principal objected to and prohibited the publication of two articles slotted to appear in a school newspaper, ironically named Spectrum. ${ }^{85} \mathrm{He}$ based his objections on the grounds that the articles fell short of acceptable journalistic standards to a degree that was detrimental to the educational function of the school newspaper. ${ }^{86}$ The Court ruled that the newspaper

82. See id. at 681.

83. A critical question unanswered after Fraser is whether deference to school determinations is limited to cases involving sexually explicit speech or extends to all conflicts involving " 'fundamental values' of public school education." Id. at 685-86. A number of factors suggest limiting Fraser to sexual speech cases. First, the Fraser opinion repeatedly emphasized the offensive quality of the "lewd" and "indecent" speech. See, e.g., id. at 683, 685. Furthermore, the Court seemed to distinguish between school disapproval of the manner of a speech, see id. at 683 ("certain modes of expression are inappropriate and subject to sanctions"), 685 ("[a] high school assembly or classroom is no place for a sexually explicit monologue"), and impermissible school discrimination against the content of a speech, see id. at 685 ("the penalties imposed [by the school district on Fraser] were unrelated to any political viewpoint"). Second, the Court cited accepted first amendment doctrine to show "limitations on the otherwise absolute interest of the speaker in reaching an unlimited audience where the speech is sexually explicit and the audience may include children," id. at 684, and found this limitation relevant to Fraser's speech, see id. at 683 (younger members of Fraser's audience may have been damaged by the sexually explicit speech). Third, the Court's emphasis on the importance of civil discourse in the democratic process is consistent with a limited reading of Fraser: "[e]ven the most heated political discourse in a democratic society requires consideration for the personal sensibilities of the other participants and audiences." Id. at 681. Moreover, Justice Brennan's concurrence specifically sought to limit Fraser's scope:

To my mind, the most that can be said about respondent's speech-and all that need be said-is that in light of the discretion school officials have to teach high school students how to conduct civil and effective public discourse, and to prevent disruption of school educational activities, it was not unconstitutional for school officials to conclude, under the circumstances of this case, that respondent's remarks exceeded permissible limits.

Id. at 687-88 (Brennan, J., concurring). Brennan's attempt to circumscribe the Court's holding might indicate that the sweep of the majority opinion was broader than he was willing to accept.

Despite these potential reasons to narrow the holding, neither the facts nor the language of Fraser were limited specifically to sexually suggestive speech. Rather, the Court's reasoning suggested that student speech need not actually interfere with the schools' work but merely appear "offensive" for schools to find a conflict with their mission. Apart from the fact that several teachers did not approve of Fraser's speech, id. at 678, the school made no showing that the speech actually disrupted student learning or incited uncivil behavior. Rather, the Court found the speech offensive not because of any evidence produced by the school authorities but because the speech was "plainly offensive ... to any mature person." Id. at 683 .

84. 484 U.S. 260 (1988).

85. Id. at 264.

86. The principal objected to one article discussing student pregnancy because he feared that 
constituted a "school-sponsored activity" representing the school's views rather than a public forum for student viewpoints because it was funded by the school and published as a function of a school journalism class. ${ }^{87}$ The student writing in the Spectrum was thus construed to be the school's curricular message, which the school was entitled to control. ${ }^{88}$

Kuhlmeier returned to an analysis based on the school's power to inculcate its curriculum. ${ }^{89}$ Citing Fraser, the Court held that the school's right to disassociate itself from student speech inconsistent with its curricular message justified suppression of the student articles. The inconsistency between the articles and the message lay in the articles' alleged violation of journalistic standards, the purported inappropriateness of their contents given the young audience, and the perception of school endorsement of possibly irresponsible behavior. ${ }^{90}$ Because the Court viewed the newspaper as an aspect of the curriculuin and therefore subject to regulation by the school, ${ }^{91}$ it followed Fraser's reasoning and deferred to the school authorities' determination of the appropriateness of the articles. The Kuhlmeier Court therefore avoided the Tinker requirement that the student speech inaterially and substantially impair the work of the school before it could be suppressed. ${ }^{92}$

Kuhlmeier extended Fraser's deference to school authorities' regula-

the identity of pregnant students might be revealed and believed that references to sexual activity and birth control would be inappropriate for younger students. He felt that the second article on divorce, in which an identified student criticized her divorced father, should have allowed the student's parents an opportunity to respond. Id. at 263.

87. Id. at 266-70. Other factors connected the Spectrum to the school curriculum: the journalism teacher selected students for the class, suggested articles, and reviewed submissions, and the principal had final review authority over the publication. Id. at 263. However, a statement of policy published in the Spectrum described the newspaper as a "student press publication," and a school board policy statement stated that "[s]chool sponsored student publications will not restrict free expression or diverse viewpoints within the rules of responsible journalism." Id. at 269. While the dissent believed that this statement created student speech rights protected by the Tinker standard, id. at 277 (Brennan, J., dissenting), the majority found this evidence "equivocal at best," id. at 269. See also Buss, supra note 7, at 512-13, 520-22 (agreeing with majority's rejection of the Spectrum as a forum for student free speech).

88. For an elaboration on the theory that the Kuhlmeier holding focused on control over communication of the school's views, see Buss, supra note 7, at 513 ("the [Kuhlmeier] decision is best explained in terms of the school's power to control its communicative resources, rather than as a power to regulate student speech").

89. Kuhlmeier, 484 U.S. at 266 ("[a] school need not tolerate student speech that is inconsistent with its 'basic educational mission' even though the government could not censor similar speech outside the school" (quoting Bethel School Dist. No. 403 v. Fraser, 478 U.S. 675, 685 (1986))).

90. Kuhlmeier, 484 U.S. at 266-67, 271-72.

91. See supra note 87 and accompanying text.

92. The Court thus refused to follow the Eighth Circuit's application of the Tinker standard. See Kuhlmeier, 484 U.S. at 266-73. The lower court had determined that the school failed to demonstrate a reasonable expectation that the censored materials would materially disrupt classwork. See Kuhlmeier v. Hazelwood School Dist., 795 F.2d 1368, 1375 (8th Cir. 1986), rev'd. 484 U.S. 260 (1988). 
tion of student speech that interferes with the inculcation of curricular messages by making a critical distinction between tolerating and promoting student speech. ${ }^{93}$ According to the Court's distinction, the first amendment requires schools to tolerate personal student speech that "happens to occur on the school premises" but is unrelated to the curriculum. ${ }^{94}$ However, because student speech that is curriculum-related could reasonably be perceived by outsiders to be approved of and promoted by the school, schools have the authority to suppress such speech. ${ }^{95}$ As a consequence, the Kuhlmeier Court seems to have further restricted application of the Tinker standard: Although Tinker explicitly protected the wearing of armbands inside classrooms where curricular speech was conducted, ${ }^{96}$ under Kuhlmeier any student speech inside the classroom could be viewed as promoted by the school and therefore subject to suppression. ${ }^{97}$ Following Kuhlmeier there may be little tolerance in the classroom for speecl divergent from the curriculum because, when the school authorities characterize all speech taking place within the classroom as the school's message, tolerating is tantamount to promoting.

As the discussion thus far suggests, the relationship of student speech to the school's curriculum is the critical factor in determining whether the speech falls under a Kuhlmeier or Tinker analysis. Kuhlmeier suggests a broader, more expansive interpretation of "curriculum" than does Tinker. Under the Kuhlmeier view, if student expression

93. Kuhlmeier, 484 U.S. at 270-71. See Searcey v. Harris, 888 F.2d 1314, 1319 n.7, 1324-25 (11th Cir. 1989) (interpreting Kuhlmeier to permit schools to practice content but not viewpoint discrimination in curriculum-related activities); see also infra notes 328-63 and accompanying text (discussing teacher responses to curriculum-related student speech).

94. Kuhlmeier, 484 U.S. at 271. The Court's use of the phrase "happens to occur" inplies speech unrelated to the school curriculum. This would include the Tinker armbands if the school had no curricular interest in the Vietnam War.

95. The Court addressed the question of "whether the First Amendment requires a school to tolerate particular student speech" that challenges the "educators" ability to silence a student's personal expression that happens to occur on the school preinises" and found that Tinker requires toleration. Id. at 270-71. However, the Court went on to question "whether the First Amendment requires a school affirmatively to promote particular student speech" and concluded that the issue "concerns educators' authority over school-sponsored publications, theatrical productions, and other expressive activities that students, parents, and members of the public inight reasonably perceive to bear the imprimatur of the school." Id.

96. Tinker v. Des Moines Indep. Community School Dist., 393 U.S. 503, 512-14 (1969).

97. See Kuhlmeier, 484 U.S. at 271 ("[noncurricular] activities may fairly be characterized as part of the school curriculum, whether or not they occur in a traditional classroom setting, so long as they are supervised by faculty members and designed to impart particular knowledge or skills to student participants and audiences"). A consistent theory is that Kuhlmeier linits only student speech that may be perceived as school-promoted and thereby falls under first amendment limitations on government speech. Yudof, Personal Speech and Government Expression, 38 CASE W. RES. L. REV. 671, 693-94 (1988) (footnote omitted) ("Kuhlmeier "valid educational purpose' test applies only to government expression in the public schools. The Tinker disruption test remains applicable to the students' own expression."). 
interferes with the school's power "to assure that participants learn whatever lessons the activity is designed to teach," 98 school officials may restrict it. In addition, the Kuhlmeier standard's protection of student speech is significantly more deferential to school authorities than the Tinker standard: "[E]ducators do not offend the First Amendment by exercising editorial control over the style and content of student speech in school-sponsored expressive activities so long as their actions are reasonably related to legitimate pedagogical concerns."99 Under Kuhlmeier's broad definition of curriculum and extensive deference to school authorities, the schools have wide power to control the curriculum $^{100}$ and to regulate and exclude student speech that diverges from it. ${ }^{101}$ Under this interpretation of the Kuhlmeier standard, ${ }^{102}$ if school authorities are careful to characterize restricted student speech as schoolsponsored and proclaim some educational justification for its suppression, a question of any impermissible motivation for suppressing the speech, even if a primiary motivation, will never be successfully raised. ${ }^{103}$

The standards developed under Fraser and Kuhlmeier reflect a very different understanding of the "work of the schools" and the "special characteristics of the school environment" than does the Tinker standard. ${ }^{104}$ To reconcile these cases, Justice Brennan articulated an alternate theory in his Kuhlmeier dissent, ${ }^{105}$ later developed further by

98. Kuhlmeier, 484 U.S. 'at 271. The Court offered two further justifications for restricting student speech: readers or listeners might be exposed to material inappropriate for their level of maturity, and the views of individual speakers might be attributed to the school. Id. at 271-73.

99. Id. at 273.

100. A school must be able to set high standards for the student speech that is disseminated under its aưspices . . . and may refuse to disseminate student speech that does not meet those standafds. ... A school must also retain the authority to refuse to sponsor student speech that might reasonably be perceived to advocate drug or alcohol use, irresponsible sex, or conduct otherwise inconsistent with "the shared values of a civilized social order," or to associate the school with any position other than neutrality on matters of political controversy:

Id. at 271-72 (qúoting Bethel School Dist. No. 403 v. Fraser, 478 U.S. 675, 683 (1986)).

101. Both Fraser and Kuhlmeier resurrected Justice Black's contention that the Tinker standard usurped control of the public schools from the state, parents, and educators and placed it in the hands of the students. See supra note 44 . The usurpation argument-first put forward by Justice Black in his Tinker dissent and now apparently accepted by a majority of the Court-is a marked doctrinal shift from recognizing and valuing student views to virtually disregarding their constitutional worth.

102. For an alternative interpretation of Kuhlmeier, see Stewart, supra note 8, at 24-25 (Kuhlmeier can be analyzed both in terms of the inculcative function of the school and of student utilization of school resources for speech purposes).

103. Cf. Board of Educ. v. Pico, 457 U.S. 853, 870-72 (1982) (first amendment prohibits school authorities from removing books from school library if primary motivation is to deny students access to viewpoints with which school authorities disagree).

104. See supra text accompanying note 34-36 (Tinker view of the schools' work); supra text accompanying notes 68-97 (describing Fraser and Kuhlmeier views).

105. Kuhlmeier, 484 U.S. at 279 (Brennan, J., dissenting). 
Professor William Buss, ${ }^{106}$ which lias greater tolerance for divergent student speech. This theory proposes that Tinker established a distinction between student speecli that intercepts the scliool's curricular message by preventing it from reaching the students and speech that contradicts it by providing an alternative message. ${ }^{107}$ Speech that intercepts the school's curricular message "materially and substantially" interferes with the schools' work, so school authorities can suppress it under Tinker. ${ }^{108}$ However, speech that contradicts and possibly diminishes the effectiveness of the school's message ${ }^{109}$ is protected by the first amendment and sliould be tolerated so long as it does not substantially interfere with or disrupt the work of the school. ${ }^{110}$

In contrast to the Brennan-Buss perspective, at least one appellate circuit has adopted the theory that school authorities can restrict student speech that conflicts with the school's curricular message. In Poling $v$. Murphy ${ }^{111}$ school authorities disqualified a high school student from candidacy for student council president after he dehvered the following speech criticizing school authorities at a school-sponsored candidates' assembly:

The administration plays tricks with your mind and they hope you won't notice. For example, why does [Assistant Principal] Davidson stutter while he is on the intercom? He doesn't have a speech impediment. If you want to break the iron grip of this school, vote for me for president. I can try to bring back student rights that you have missed and maybe get things that you have always wanted. All you have to do is vote for me,

106. See Buss, supra note 7, at 516-22 (noting distinction in Tinker between intercepting and contradicting school's communication, and rationalizing Kuhlmeier under Tinker standard on grounds that purpose of school newspaper was to teach and student disregard of acceptable joumalistic standards interfered with this teaching).

107. Brennan distinguished between speech that "directly prevent[s] the school from pursuing its pedagogical mission" and that which "frustrates the school's legitimate pedagogical purposes merely by expressing a inessage that conflicts with the school's, without directly interfering with the school's expression of its message." Kuhlmeier, 484 U.S. at 279 (Brennan, J., dissenting). The latter category, according to Brennan, encompasses interference that schools should tolerate alongside their educational mission unless it reaches the material and substantial interference necessary for suppression under the Tinker standard. Id. at 280-81.

108. For example, schools can forbid a student to discuss the World Series during a class on the flrst amendment. See Bethel School Dist. No. 403 v. Fraser, 478 U.S. 675, 691 n.1 (1986) (Stevens, J., dissenting).

109. [Disruptive speech] occurs when a student argues for an explanation of the cause of the Civil War inconsistent with the one contained in the history course textbook or when a student insists that socialisin, not capitalism, is the more just economic system. There is no doubt that, in either of these examples, the student speech might be "disruptive" in the sense that it might undermine the school's attempt to teach what the school believes should be taught.

Buss, supra note 7 , at 517.

110. "[P]ublic educators must accommodate some student expression even if it offends them or offers views or values that contradict those the school wishes to inculcate." Kuhlmeier, 484 U.S. at 280 (Brennan, J., dissenting).

111. 872 F.2d 757 (6th Cir. 1989), cert. denied, 493 U.S 1021 (1990). 
Dean Poling. ${ }^{112}$

Poling's first draft of the speech had been reviewed by a faculty member, who advised Poling to change the reference to the administration's "iron grip." After the review, however, Poling added the remark about the assistant principal's stutter. ${ }^{113}$ The school authorities disqualified Poling from the election because of this speech, which the principal found " 'inappropriate, disruptive of school discipline, and in bad taste." "114

Applying the lenient standard of scrutiny established in Fraser and Kuhlmeier, the court deferred to the judgment of the school authorities. ${ }^{115}$ The Sixth Circuit affirmed a grant of summary judgment in their favor, adopting the view that schools have broad discretion to regulate student speech. The court initially determined that the election assembly and election were both "school-sponsored" activities within the meaning of Kuhlmeier. ${ }^{116}$ Applying the Kuhlmeier test, the court then concluded that the school authorities had acted appropriately in sanctioning the student speech, explaining that speech sponsored by the school is subject to "greater control" by school authorities than personal speech because educators have a legitimate interest in assuring that students in sponsored activities learn intended lessons and values related to proper pedagogical concerns. ${ }^{117}$ Although it recognized that independent thought and frank expression "occupy a high place on our scale of values, or ought to," 118 the court found that "shared values of a civilized social order," "119 namely discipline, courtesy, and respect for authority, fall within the umverse of legitimate pedagogical concerns. ${ }^{120}$ Thus, "[i]t was not irrational, to say the least, for the school authorities to take offense at a remark that was calculated to get [Poling] votes at the expense of the assistant principal's dignity." 121

The court in Poling never explicitly examined the appropriateness of the school authorities' determinations and disciplinary actions, stating

112. Id. at 759 .

113. Id.

114. Id. Although students responded to Poling's speech with comments such as "way to go, Dean" and "we don't like him either," the evidence suggested that "[t]he clapping, yelling, and so forth did not go 'above or beyond that present for any of the candidates.' "Id. The principal was upset, however, and other students "complained that Dean Poling had gained an unfair advantage." Id. at $759-60$.

115. Id. at 762 ("I]]ocal school officials [are] better attuned than we to the concerns of the parents/taxpayers who employ them").

116. "School officials scheduled the assembly to be held during school hours and on school property. ... And they vetted the speeches in advance, correcting inappropriate grammar and attempting to weed out or temper inappropriate content." Id.

117. Id.

118. Id.

119. Id. (quoting Bethel School Dist. No. 403 v. Fraser, 478 U.S. 675, 683 (1986)).

120. Id.

121. Id. at 763 (emphasis added). 
merely that what the school board should have done was "not for us to say. Such a question, we believe, represents a judgment call best left to the locally elected school board, not to a distant, life-tenured judiciary." 122 Assuming a stance deferential to the school authorities, the court did not consider whether the authorities' disapproval of Poling's ideas was proper, ${ }^{123}$ holding only that Poling communicated his ideas in an unacceptable manner that gave the authorities the ability to sanction him. ${ }^{124}$

The case of Dean Poling reveals the breadth of the Fraser/ Kuhlmeier doctrine. On one level, it illustrates the probleins inherent in allowing the suppression of student speech, classified in terms of school sponsorship that is construed so broadly that almost any student expression on school property can be connected somehow to the learning process. Moreover, on a second level, courts have become very deferential to suppression of student speech by school authorities who can offer a reason for their action that is related to some pedagogical objective. This deference leaves open an expanding crater into which school authorities may cast speech they dislike if the speech is tainted by minor breaches of decorum, as in Poling. Even when student speech does not demonstrably interfere with or disrupt either the schools' work or student knowledge of the intended lesson, Poling indicates that schools are under no constitutional obligation to allow viewpoints that diverge from curricular lessons, that criticize school administrators, or that support unpopular views. They can simply censor expression that they determine conflicts with "legitimate pedagogical concerns" such as discipline, courtesy, civility, and respect for authority. As a result of the current doctrinal emphasis

122. Id. at 761. Although the court of appeals recognized that it was "obviously not the ideal body" to judge the actions of the school authorities, the tone of the court's language suggested that it did not fully agree with the school's actions. See, e.g., id. ("[it] may well be that a more relaxed or more self-assured administration would have let the incident pass without declaring [Poling] ineligible, and perhaps that is what this administration ought to have done")

123. A dissenting opinion examined Poling's speech, assessed its value in the school context, and concluded that it was political and therefore should have been evaluated under Tinker rather than Kuhlmeier. Id. at 765 (Merritt, J., dissenting). Judge Merritt believed that "[t]he Court [in this case] has applied the wrong First Amendment test to this student's political speech and has therefore reached the wrong result." He felt that the issue was not of "civility" but of "disruption," for which there was no evidence. Id. Furthermore, Judge Merritt limited both the Fraser and Kuhlmeier holdings to specific situations, rendering them inapplicable to Poling: He distinguished Fraser as narrowly pertaining to "sexually explicit and salacious student speech," and Kuhlmeier as "a school's decision not to permit a student paper to invade the right of privacy of an unwed, pregnant student." Id. The nature of Poling's speech, political expression criticizing the school administration, was more important than whether it was connected with the school's curriculum or merely personal. Poling's speech, as political expression, should have been entitled to greater first amendment protection, whether or not it confiicted with the school's intended lesson.

124. Id. at 763 ("[t] he art of stating one's views without indulging in personalities and without unnecessarily hurting the feelings of others surely has a legitimate place in any high school curriculum"). 
on the work of the schools as the inculcation of values, speech rights within the schools are virtually unprotected.

II

\section{A VIEW FROM EDUCATIONAL RESEARCH: THE WORK OF The Schools as Conceptual DeVelopment}

The mission of the schools should be based on the conceptual-development model because this theory explains what takes place at the core of the learning process better than the inculcation-of-values model. The difficulty with understanding education in inculcative terms is that inculcation does not adequately describe either the educational process or the principles on which schools are intended to function. ${ }^{125}$ An alternative view of education is based on principles and insights gleaned from a substantial body of literature in the fields of psychology, education, and cognitive science. ${ }^{126}$ The consensus of researchers and theorists in these fields is that the learning process is properly characterized as developing thinking skills. This view of learning as "conceptual development"127 is

125. An understanding of education as inculcation fails to correspond with accepted learning theory, see infra notes 128-72 and accompanying text, espoused learning objectives, see infra notes 173-99 and accompanying text, or principles of democratic education, see infra notes 218-29 and accompanying text.

126. For a definition of "cognitive science," see supra note 20.

127. Conceptual development encoinpasses both cognitive and affective learning. See supra note 18 (briefiy defining conceptual development); see also Krathwohl, Cognitive and Affective Outcomes of Learning, in 2 THE ENCYCLOPEd1A of EduCATION 196 (L. Deighton ed. 1971) ("[c]ognitive learning consists of not only the acquisition of knowledge but also the mental abilities and skills which enable a student to use his knowledge in problein solution"). Cognitive learning involves the thinking process. See, eg., TAXONOMY OF EdUCATIONAL OBJECTIVES, HaNdBook I: Cognitive Domain 7 (B. Bloom ed. 1956) [hereinafter Bloom's TAXoNOMY] (the "cognitive domain" focuses on the "recall or recognition of knowledge and the developinent of intellectual abilities and skills").

My use of the term "conceptual development" is akin to the concept of "cognitive development," a term closely associated with the Piagetian theory of developmental stages of learning. For a critical appraisal of Piagetian theory in light of recent research and theory on cognitive development, see Gelman \& Baillargeon, A Review of Some Piagetian Concepts, in Handbook of Child Psychology 167, 214-15 (J. Flavell \& E. Markinan 4th ed. 1983) (questioning validity of Piagetian theory but agreeing with its fundamental insight that cognitive development involves "assimilation" of information into cognitive structures and "accominodation" of cognitive structures to new information). The following excerpt froin a definition of cognitive development could also describe conceptual development:

The study of cognitive development concerns changes with ... the system of what wc know and changes in the way in which that system interacts with other facets of behavior. Characteristics of human intellectual functioning such as thinking, planning, knowing, relating, classifying, creating, and problem solving have been traditionally labeled as cognitive processes. More recent views have broadened this characterization to include attention, perception, memory, imagery, and motor learning, among others. These processes are not solely intellectual but are clearly infiuenced by or under the control of higher-order intellectual processes. Further, affective facets of life are linked through beliefs, attitudes, judginents, and values with the cognitive apparatus and therefore cannot be excluded from a consideration of cognitive infuences. 
quite distinct from and contrary to an understanding of learning as the inculcation of values. If legal doctrine in the area of school speech is to continue to rest on notions of the "work of the schools," then the courts will have to come to terms with research demonstratimg that this work involves the development of minds as well as the recollection of schoolselected facts and ideas.

\section{A. The Conceptual-Development Model of Learning: Principles from Cognitive Research}

Research in the cognitive sciences into the way we gain knowledge and formulate ideas views the functioning of the mind in terms of information processing. ${ }^{128}$ The learning process involves not only the recall of information but also, and most importantly, the building of cognitive structures-intellectual frameworks for conceptualization that hold information in some comprehensible form. ${ }^{129}$ As well as adding new information to one's cognitive structures, the learning process involves reformulation of the cognitive structures themselves to account for new, different, and more complex information. ${ }^{130}$ An increase in knowledge, for example, is a function not only of acquiring but also of developing the mental tools sufficient to organize new information. ${ }^{131}$ In addition to the recitation of information, knowledge requires the comprehension and association of ideas. Most significantly, research suggests that the learner constructs rather than simply receives knowledge. ${ }^{132}$ The quality of the knowledge one acquires, then, is a function of active intellectual inquiry.

Di Vesta, Cognitive Development, in 1 ENCyClopedia of Educational Research 285, 285 (H. Mitzel 5th ed. 1982) (citations oinitted).

128. For a summary description of information-processing theory, see Hastie, $A$ Primer of Information-Processing Theory for the Political Scientist, in Political Cognition 11 (R. Lau \& D. Sears eds. 1986). The importance of this theory is indicated by the "simple fact that most of the interesting research in psychology today, including virtually all of its subfields, concludes with theoretical analyses in terms of the information-processing principles." Id. at 16.

129. These cognitive structures, frequently referred to as "schemata," are described in Lau \& Sears, Social Cognition and Political Cognition: The Past, the Present, and the Future, in PolrTiCaL CoGNITION, supra note 128 , at 347,349 .

130. See, e.g., id. at 352-54 (development of expertise in a particular field illustrating operation of cognitive structures in learning).

131. Gaining knowledge through critical thinking is inseparable from a knowledge base. While "[b]ackground knowledge is essential for critical thinking in a given field," it is nevertheless true that "full understanding of a field requires the ability to think critically in the field." Ennis, Critical Thinking and Subject Specificity, Educ. ReSEARCHER, Apr. 1989, at 4, 7. Moreover, "critical thinking reflection on the part of each and every learner is an essential precondition of knowledge." Paul, Bloom's Taxonomy and Critical Thinking Instruction, EDUC. LEADERSHIP, May 1985, at 36, 38.

132. See Paul, supra note 131 , at 38 (" $[\mathrm{K}]$ nowledge is not something that can be given by one person to another. It cannot simply be memorized out of a book or taken whole cloth from the mind of another."). 
Three general principles of cognitive and conceptual development reveal both that the inculcative model has limits and that the learning process is essential to effective education. First, students are not "empty vessels" waiting passively to be filled by the school's lessons. Rather, they come to the learning process with a base of knowledge and values as well as some cognitive structures already in place. ${ }^{133}$ Second, the building of cognitive structures, although greatly influenced by schooling, is ultimately a function of the learner, not the school. ${ }^{134}$ Knowledge is not simply inculcated or instilled directly by instruction but is assimilated or accommodated by the learner, ${ }^{135}$ who should not be viewed as merely a recipient of information but rather as a "constructor of meaning."136 Third, both the building and reformulation of cognitive structures are substantially enhanced by the learner's expression of ideas. ${ }^{137}$

\section{Students' Existing Knowledge and Cognitive Structures Are Major Influences on Learning}

The first principle of conceptual developinent-that students already have a significant base of knowledge, values, and cognitive structures in place-is an iniportant and recurrent theme in educational research. Cognitive science recently has denonstrated, for example, that students arrive on the school scene already acquainted to some degree with what will be taught. ${ }^{138}$ Specifically, "[s]tudents approach learning with existing strategies, beliefs, and naive forms of knowledge which influence how they mcorporate the knowledge imparted in instruction."139 Furthermore, students' preexisting knowledge and cognitive skills can be either advantageous or detrimental to their progress in any

133. See infra text accompanying notes 138-44.

134. See infra text accompanying notes 145-64.

135. See Vosniadou \& Brewer, Theories of Knowledge Restructuring in Development, 57 REV. EDUC. RES. 51, 51 (1987) ("[w] hereas some learning may consist of the acquisition of 'totally' new knowledge, most of the learning that occurs in life is either incorporated within prior knowledge (Piaget's assimilation) or modifies prior knowledge (Piaget's accommodation)" (citations omitted)).

136. "The reader is now viewed as a constructor of meaning rather than a recorder of messages; we recognize that a text provides only part of the information that a reader needs to make sense of the situation that it describes. The reader supplies the rest." Glaser, Cognitive Science and Education, 40 INT'L Soc. SCI. J. 21, 26 (1988).

137. See infra text accompanying notes 165-72.

138. Learners come to instruction with bits of specific prior knowledge and skill relevant to the domain at hand.

It is now recognized, however, that learners also come with a variety of relevant preconceptions. Some are alternative creditable views that may conflict with teacher concepts. Some are misconceptions that may be quite wrong or misleading.

Snow, Toward Assessment of Cognitive and Conative Structures in Learning, EDUC. RESEARCHER, Dec. 1989, at 8, 9; see also Torney-Purta, From Attitudes and Knowledge to Schemata: Expanding the Outcomes of Political Socialization Research, in Political Socialization, Citizenship EDUCATION, AND DEMOCRACY 98 (O. Ichilov ed. 1990) (political socialization research indicates young people have significant knowledge, viewpoints, and values even at early ages).

139. Glaser, supra note 136 , at 21-22. 
given field of study. ${ }^{140}$

This principle of conceptual development has important implications both for advancing educational quality and for proinoting student expression. It reveals that student ideas play an important forinative role in what students learn from the curriculum. To effectively achieve desired educational goals, the teacher should ascertain both what each student already knows and believes, and how students organize their knowledge and behefs. ${ }^{141}$ Because the quality of students' existimg knowledge and cognitive structures determines how they will respond intellectually to new ideas, their extant knowledge will greatly influence both what they learn from the school's curricular inessages and their progress toward the school's curricular objectives. ${ }^{142}$ Research has shown, for example, that sociocultural value differences between student and school, particularly between poor and minority students and mainstream school officials, have a negative impact on the learning process. ${ }^{143} \mathrm{By}$ focusmg on the psychological development of children, schools have successfully implemented programs to mitigate these problems by adjusting and reconciling the underlying value differences ainong parents, students, teacliers, and administrators. ${ }^{144}$

140. See id. at 22. Much of the research has focused on transferability of knowledge and cognitive skills from one domain to another and has recently indicated that both knowledge and cognitive structure specificity and general cognitive ability are necessary to solve problems optimally. See Ennis, supra note 131 (critical thinking ability cannot be separated from subject matter knowledge, but is not domain specific); McPeck, Critical Thinking and Subject Specificity: A Reply to Ennis, Educ. RESEARCHER, May 1990, at 10 (critical thinking skills are both general and specific, but frequently function in relation to domain specificity); Perkins \& Salomon, Are Cognitive Skills Context Bound?, EDuc. RESEARCHER, Jan.-Feb. 1989, at 16, 16 ("[g]eneral and specialized knowledge function in close partnership"); see also Ennis, The Extent to Which Critical Thinking is Subject-Specific: Further Clarification, EDUC. RESEARCHER, May 1990, at 13 (general critical thinking skills transfer across a variety of domains).

141. See generally Snow, supra note 138, at 8 (new concepts and proposed models for assessing learner developments and weaknesses).

142. See Anderson, Some Reflections on the Acquisition of Knowledge, EDUC. RESEARCHER, Nov. 1984, at 5, 8 ("[t]he knowledge a person already possesses is the principal determiner of what a person can come to know").

143. See Comer, Educating Poor Minority Children, Scr. AM., Nov. 1988, at 42, 44 ("a basic problem underlying the [urban] schools' dismal academic and disciphnary record ... [is] the sociocultural misalignment between home and school").

144. See id. at $42-48$ (describing urban school program that fostered communication and interaction between poor and minority students, their parents, and school staff to improve students' progress); see also Cauce, Comer \& Schwartz, Long Term Effects of a Systems-Oriented School Prevention Program, 57(1) AM. J. ORTHOPSYCHIATRY 127, 127-31 (1987) (comprehensive analysis of methods employed, results obtained, and implications for education of the disadvantaged); Comer, The Yale-New Haven Primary Prevention Project: A Follow-up Study, 24 J. AM. ACAD. ChILd Psychiatry 154 (1985) (same). 


\section{Cognitive Structures Are Learner, Not School, Functions}

The second principle of conceptual development-that building cognitive structures is a function of the learner ${ }^{145}$-draws on the idea that learning is a highly autonomous and active process. ${ }^{146}$ This stands in contrast to the directed and receptive processes implicit in the inculcative model. Political socialization research indicates that although the school is an important mfluence on a student's knowledge and intellectual development, it is the mdividual's personal thought processes that determine what is learned. For example, teaclers and parents control "what a child sees of politics; they do not determine, however, what the clild constructs of politics, since children do not simply reproduce adult ideas."147 Although cognitive theorists distinguish between instructed-formal and constructed-informal knowledge, they recognize that even formal knowledge is a form of construction that is "provoked by certain types of experiences" and "develops out of the child's imteraction with school curricula." 148

145. See Torney-Purta, Political Cognition and Its Restructuring in Young People, 32 HuM. DEv. 14, 15 (1989). Using cognitive theory to reexamine previous research on political socialization, Torney-Purta notes the importance of

the idea of schema, or representation, conceived of as a cognitive structure that organizes previously acquired information, influences memory and problem solving, and relates to attitudes. A schema is not a faithful reflection or copy of a reality existing in the world but a structure constructed by the individual.

Id. (emphasis added); see also Snow, supra note 138, at 9 (three phases of learning: "the accretion of new information, and its chunking, elaboration and connection to existing knowledge[,] its restructuring, through which new knowledge organizations are formed ... and, finally, the tuning or adaptation and practice of knowledge structures in particular uses"); Vosniadou \& Brewer, supra note 135, at 52 ("accretion [gradual accumulation of information], tuning [interpreting categories], and restructuring [creation of new knowledge structure] function to characterize the kinds of changes that occur as a product of learning, rather than the processes or mechanisms through which new knowledge is acquired").

146. Recognition of the learner's involvement in the learning process is consistent with the first amendment value of autonomy. Cf. van Geel, The Search for Constitutional Limits on Governmental Authority to Inculcate Youth, 62 TEX. L. REv. 197, 252-54, 289-91 (1983) (arguing that first amendment is intended to serve values of self-fulfillment, self-realization, and autonomy, and suggesting that schools be required to include alternative viewpoints as a matter of fairuess).

147. J. Torney-Purta, Political Socialization, 25-26 (rev. ed. Dec. 1988) (unpublished manuscript, originally prepared for delivery at Citizenship for the 21st Century: A National Conference on the Future of Civic Edueation, Washington, D.C., Oct. 6, 1988, sponsored by the Foundation for Teaching Economics) (on file with author); see also Torney-Purta, supra note 138, at 98 (implications of "schema," which are important to study of political socialization generally and of children in particular).

148. Prawat, Promoting Access to Knowledge, Strategy, and Disposition in Students: A Research Synthesis, 59 REV. EDUC. RES. 1, 2 (1989). The quality of one's knowledge is primarily a function of access to knowledge, which depends on organization and awareness. Knowledge base, strategies (approaches for dealing with knowledge), and dispositions (factors that influence motivation of learners regarding approaches and strategies) are significant in the acquisition of and access to knowledge. See id. Cf. Vosniadou \& Brewer, supra note 135, at 52 ("[r]estructuring refers to changes in knowledge that involve the creation of new structures ... [that] arc constructed either to reinterpret old information or to account for new information"). 
The intellectual value of knowledge does not lie solely with the facts learned. Rather, and more importantly, cognitive psychological tlieory empliasizes both the quality of connections learners make within their personal cognitive structures witl respect to knowledge gained and the sophistication of their cognitive structures generally. Understanding is not "a binary concept (i.e., having or not having conceptual level understanding).... [It is rather] a matter of degree. A tlorough understanding of something requires knowledge of everything to which it relates." 149 The acquisition of values is similarly a function of student construction. For exainple, affective-developinent research finds that the acceptance of values is largely student-determined. ${ }^{150}$

Cognitive researchers describe learning as an imteractive process between students and the curriculum that is quite different from the view of learning as the inculcation of curricular ideas. For example, these researchers believe that rote instruction is considerably less effective than interactive inethods even when the objective is meinorization and reproduction of a given body of knowledge. ${ }^{151}$ Learners are best able to comprehend material when they can actively connect it to their own cognitive structures. ${ }^{152}$ Education, according to cognitive researchers, can and should "inove control of learning gradually from tutor to

149. Prawat, supra note 148, at 6; see also Brown, Collins \& Duguid, Situated Cognition, EDuc. RESEARCHER, Jan.-Feb. 1989, at 32 [hereinafter Situated Cognition] (teaching methods should recognize the "situated nature of knowledge").

150. See D. Krathwohl, B. Bloom \& B. Masia, Taxonomy of Educational Objectives, HandBooK II: AFFective Domain 139-40 (1964) [hereinafter Taxonomy HANDBOOK II] (attempt to organize learning objectives that "emphasize a feeling tone, an emotion, or a degree of acceptance or rejection" of an idea, id. at 7 , as a companion work to Bloom's Taxonomy's treatment of cognitive objectives, see infra notes 173-84 and accompanying text). The Taxonomy Handbook $I I$ addressed the question of how a student progressively acquires or accepts values. TAXONOMY HANDBOOK II, supra, at 139-40. The authors believed that the acquisition of values in schooling is largely volitional on the part of students in that "it is motivated, not by the desire to comply or obey, but by the individual's coinmitment to the underlying value guiding the behavior." Id. at 140. Compare id. at 119-20 ("Acquiescence in Responding") with id. at 179 ("Willingness to Respond"). While the taxonomy concept has been largely superseded by more rccent research, the fundamental understanding of learning internalized in the learner and ultimately volitional is consistent with newer theories on how students respond affectively to learning opportunities. See Prawat, supra note 148, at 29-32 (importancc of motivation in learning, knowledge acquisition, and access); Snow, supra note 138 (methods of studying conative learning).

151. See Prawat, supra note 148, at 3, 10 (discussing distinction between conceptual knowledge and procedural knowledge acquired through rote memorization and concluding that it is much less likely that procedures will be retrieved and used appropriately when unconnected to a conceptual knowledge base); see also Cognition and Technology Group at Vanderbilt, Anchored Instruction and Its Relationship to Situated Cognition, EDUC. RESEARCHER, Aug.-Sept. 1990, at 2 (describing the educational practice of anchoring instruction in situations that engage students as experts), 3 ("[w] hen people learn new information in the context of meaningful activities ... they are more likely to perceive the new information as a tool rather than as an arbitrary set of procedures or facts").

152. See Prawat, supra note 148, at 5-19 (connections between knowledge and cognitive structures, and methods for fostering connections). 
learner" 153 and go "beyond educating memories to educating minds, which is what education should be about."154

A corollary to this principle of the development of cognitive structures is the influence of motivational and volitional factors, termed "affective"155 or "conative,"156 on the learning process. Confidence, selfefficacy, ${ }^{157}$ "[i]nterest, purposeful striving, persistence, action control, intellectual playfulness, appreciation, imagination-all are aspects of mstructional learning." 158 Critical thmking, even for students with welldeveloped cognitive abilities, is enhanced when they have the confidence, persistence, and imagination necessary to use their abilities effectively. ${ }^{159}$ Although learners' dispositions to learn are a prominent factor in their acquisition and utilization of knowledge, motivation is also necessary for successful learning. ${ }^{160}$

This view of education does not dispute that schools appropriately exercise their authority when they establish a curriculum, implement it by imparting material to students, and require students to demonstrate that they have received the curricular instruction by repeating or modeling it im examinations or other forns of evaluation. ${ }^{161}$ However, the conceptual-development model recoginzes that schools can never guarantee that students will accept the intended lessons. ${ }^{162}$ Furthermore, conform-

153. Snow, supra note 138 , at 12.

154. Perkins \& Salomon, supra note 140 , at 24.

155. See TAXONOMY HANDBOOK II, supra note 150, at 7 (concept of affective development focuses on students' "interests, attitudes, appreciations, values, and emotional sets or biases").

156. "Conative" is to "hav[e] the characteristics of or involv[e] conation," WEBSTER's THIRD New InTERnational Dictionary 468 (1986). "Conation" is defined as "[t]he conscious drive to perform apparently volitional acts with or without knowledge of the origin of the drive." Id.

157. "Self-efficacy" describes the students' sense of their own abilities or achievements. See Prawat, supra note 148, at 29 (relationship of "self-attributes about achievement" to learning).

158. Snow, supra note 138 , at 11 .

159. See Norris, Can We Test Validly for Critical Thinking?, Educ. ReSEARCHER, Dec. 1989, at 21,22 ("critical thinking enables people to partake rationally in the decision making of a democratic society" and "is justified and motivated in educationally satisfactory ways").

160. See Prawat, supra note 148, at 25-33. Student motivation to lcarn and engage in complex cognitive operations is a learnable skill that promotes effective learning transfer, which "suggests that the more traditional motivational argnment (e.g., if students would do it, they could) needs to be turned on its head (e.g., if students could do it, they would . . .)." Id. at 29.

161. See, e.g., Ambach v. Norwick, 441 U.S. 68, 78-79 \& n.8 (1978) (describing instructional requirements designed to promote patriotism and civil service).

162. Student response ranges from merely receiving to actually valuing the instruction. The degree to which students accept instruction becomes their responsibility when they value it. See, e.g.. TAXONOMY HANDBOOK II, supra note 150, at 38-43, 98-153.

The Court has recognized that "[s]chool officials do not possess absolute authority over their students." Tinker v. Des Moines Indep. Community School Dist., 393 U.S. 503, 511 (1969) (rejecting notion of students as "closed-circuit recipients of only that which the State chooses to communicate"); see also West Virginia State Bd. of Educ. v. Barnette, 319 U.S. 624, 642 (1943) ("If there is any fixed star in our constitutional constellation, it is that no official, high or petty, can prescribe what shall be orthodox in politics, nationalism, religion, or other matters of opinion, or force citizens to confess by word or act their faith therein.") (emphasis added). But see Bethel School 
ity to prescribed values that are forced or coerced by schools is not a valid reflection of students' actual acquisition of those values: ${ }^{163}$ Requiring students to comply with a behavioral norm does not necessarily result in increased affinity for the value that underlies that norm. On the contrary, research has suggested, for example, that requiring students to participate in patriotic rituals during their later years of schooling may tend to diminish their adherence to the patriotic values sought to be instilled. ${ }^{164}$

\section{Expression Is Vital for Conceptual Development}

The third principle of conceptual development-that expression is related to and enhances student conceptual development--has been increasingly recognized by social scientists working in the areas of cognition and education. ${ }^{165}$ The learning process, in which students advance from an insufficient, formative level of knowledge to a higher level by formulating and reformulating their thought structures, is essentially an expressive act. ${ }^{166}$ Conceptual development involves actual contribution by the learner because developing one's cognitive structures is a more active process than creating mental hists of received opinions. Students learn by working with ideas, attenpting to fit them into their cognitive structures, and reformulating those structures as necessary. ${ }^{167}$

Dist. No. 403 v. Fraser, 478 U.S. 675,683 (1986) (suggesting that schools can compel students to conform their behavior to curricular norms).

163. See TAXONOMY HANDBOOK II, supra note 150, at 181 (act of valuing or accepting a belief "is motivated, not by the desire to comply or obey, but by the individual's commitment to the underlying value guiding the behavior"); see also Barnette, 319 U.S. at 643-44 (Black and Douglas, $\mathrm{JJ}$., concurring) (words uttered under coercion will not produce belief in those words).

164. See Torney-Purta, Political Socialization and Policy: The United States in a Cross-national Context, in 1 Child Development Research and Social Policy 471, 487-90 (H. Stevenson \& A. Siegel eds. 1984) (international study of education indicated that "an open classroom climate is a positive factor in producing knowledgeable citizens supportive of democratic values, while patriotic ritual and rote teacling methods are negative factors"); see also van Geel, supra note 146, at 284-86 (current research is inadequate to conclude that political-socialization education produces patriotic citizens).

165. "Almost all of the developmentally based approaches argue for the active participation and involvement of students in the educational process." J. Torney-Purta, supra note 147, at 31; see also Perkins \& Salomon, supra note 154, at 22 (studies demonstrating cognitive ability increased when learners formulated their own rules after being given examples); Prawat, supra note 148, at 33 (research showed students learned better when they were encouraged to articulate their own thoughts, particularly when confronted with alternative views that exposed them to the limits of their own thinking); Torney-Purta, supra note 147, at 106-12 (students demonstrated substantial advances in schema development when involved in interactive, problem-solving, think-aloud learning experience in international economics).

166. See Prawat, supra note 148, at 14-15 (emphasizing role of verbalization in building and reformulating cognitive structures).

167. See generally Posner, Strike, Hewson \& Gertzog, Accommodation of a Scientific Conception: Toward a Theory of Conceptual Change, 66 ScI. EDUC. 211 (1982) [hereinafter Accommodation of a Scientific Conception] (theory of accommodation and low studénts cliange central concepts in the process of learning). 
To inove to higher levels of understanding, students inust becoine aware of their knowledge and its limits. ${ }^{168}$ The development of students' awareness of their own knowledge through the process of discourse or dialogue greatly facilitates the development of their cognitive structures. While learners may not have to hiterally articulate a fact or idea to be able to integrate it into their cognitive structures, their conceptual development is advanced when they authentically participate in dialogue as speakers or listeners. ${ }^{169}$ Learners must apply their intelligence to facts by comparing, classifying, summarizing, interpreting, analyzing, synthesizing, imagining, or evaluating. When this is done for them by the teacher or the textbook, students are not engaging in cognitive processes but merely stating, or restating, received ideas. Students engaging in such repetitious acts are not advancing their knowledge beyond the level of a novice. ${ }^{170}$ This does not mean that modeling and gnidance by the teacher is inappropriate, but rather that learning is best promoted when teachers engage students in the material rather than directly provide them with information. The point is that students themselves have to engage authentically in the material in order to operate with and advance their intellectual skills. ${ }^{171}$

168. Students must first recognize that the new information is related to what they already know; they then have to link this information to two types of prior knowledge-that which is consistent with the [new knowledge] and that which is incompatible with those notions. It is the latter connection that leads to the realization that their own ideas are not complete or satisfying explanations and that the [new] view is a more convincing and powerful alternative.

Prawat, supra note 148, at 12-13; see also id. at 5-19 (describing intelligence in terms of accessibility of knowledge-in addition to the quality of connections between different types of knowledge in cognitive structures, awareness of knowledge is also vital to promote access to and utilization of that knowledge).

169. Oral and written verbalization is an important means for students both to gain access to their knowledge and to reformulate their cognitive structures in light of knowledge gains:

Verbalization appears to be the best means for achieving [refiective awareness of one's knowledge]. Thus, there is considerable support for the notion that discourse or dialogue plays a vital role in promoting student understanding and reflective awareness in a number of academic domains ....

... In the process of relaying thoughts to others, we also relay them to ourselves. It is the process of formulating thoughts into communicable representations that is most important in developing an awareness of what one knows. Through verbalization, our thoughts become an object for reflection....

In finding words to express ideas to others, we wind up reshaping them for ourselves. Prawat, supra note 148, at 14.

170. See Bloоm's TахоNомy, supra note 127, at 68 . A student who simply repeats what the teacher has taught is engaging in the lowest level of cognitivc activity. While the act of repeating complex knowledge is likely to require greater cognitive skill and development than repeating simple elements of knowledge, cognitive theory holds that the richness of connections and relationships among and within cognitive structures measures understanding. See Prawat, supra note 148, at 5-6 ("[s]eeing relationships between units of knowledge is the sine qua non of conceptual understanding").

171. See Situated Cognition, supra note 149, at 34 (importance of authentic activity, defined as the "ordinary practices of the culture"); Cognition and Technology Group at Vanderbilt, supra note 151 , at 6-8 (importance of authenticity in instruction). 
Learning in accordance with conceptual development, therefore, both encourages and requires students to actively think for themselves and to articulate their thoughts. This third principle of cognitive and conceptual development requires schools to be substantially tolerant of, and indeed to promote, all forms of student expression because such expression advances the students' conceptual development. Thus, under conceptual-development theory, learming is advanced when student speech is valued by educators. ${ }^{172}$

\section{B. Conceptual Development Is the Schools' Acknowledged Mission}

An examination of the actual work of the schools reveals that schools themselves declare conceptual development to be their method of teaching students. This Part reviews the goals that state education agencies and local school districts have developed for use in the schools.

\section{Bloom's Taxonomy}

Much of the policy embraced by educational autlorities is derived from the work of Benjamin Bloom. His Taxonomy of Educational Objectives, ${ }^{173}$ an extremely influential analysis of schools' learning objectives, studied the range of schools' asserted educational goals ${ }^{174}$ and revealed

172. Child psychiatrist Bruno Bettelheim emphasized the importance of valuing the ideas and viewpoints of children:

There is hardly a better way to convince our child that his opinions are important to us than to inquire about them, in order not to criticize or refute them but to ponder them seriously. The best result of our being interested in our child's views of why we act toward him as we do, and of our taking his views seriously, is that this will greatly encourage the child's feeling that our views of him are not arrived at arbitrarily.

B. Bettelheim, A Good Enough Parent: A Book on Child-Rearing 77 (1987). This does not mean that parents, and teachers by analogy, must acquiesce, give in to, or not otherwise correct the child. Rather, parents (and teachers) should strive to see things both through the child's imperfect, formative, and developing views and through their own adult (and curricular) views. This should enable adults to adjust their conduct to help the "child to comprehend something in the way [adults] think is correct." Id. at 51.

Bettelheim's insights reveal the fundamental distinction between inculcative and conceptual development approaches to edueation: while both may claim the high ideal of educating for democracy and the knowledge, critical ability, tolerance, and rational deliberation that it entails, see infra notes 218-29 and accompanying text (discussing education as promoting the abilities for democratic participation), only conceptual development attends to the real needs, interests, and abilities of the child at the child's level. Inculcative education falls short by treating children as less than adults in terms of their competence regarding their individual rights but then proceeding to ignore the childlike qualities of their developing ideas and attitudes. The education of children should be characterized less by the suppression of their childlike behavior and more by modeling appropriate alternative conduct. The law (and educational policies and practices) should give greater weight to the "personhood" of children by recognizing their individual rights and be more tolerant when children fall short of adult standards.

173. Bloom's Taxonomy, supra note 127.

174. Bloom's group began by "gathering a large list of edueational objectives from our own institutions and the literature." Id. at 15 . The ensuing preliminary taxonomy was discussed widely with group members, colleagues, graduate students, and other groups of teachers and edueational 
that they center on the acquisition of knowledge and the development of cognitive skills by students. ${ }^{175}$ The major innovations of Bloom's Taxonomy were its characterization of schools' learning objectives in cognitive terms and its organization of these objectives into an interconnected and progressively more complex sequence of six mental skills-knowledge, comprehension, application, analysis, synthesis, and evaluation ${ }^{176}$-that encompass many of the processes involved in the development of cognitive structures and arrangement of infornation within them. ${ }^{177}$

It is important to keep in mind that Bloom's Taxonomy developed a scheme of classification for objectives that schools set for themselves. It is not, and never purported to be, a systein for describing the cognitivedevelopment process. ${ }^{178}$ Bloom's Taxonomy is valuable to precollege education because it articulated the actual goals of schools both in cogni-

specialists. A prehminary draft was distributed to "a large group of college and secondary school teachers, administrators, curriculum directors, and educational research specialists," who contributed their suggestions and criticisms. Id. at 8,9 .

175. The authors of the Taxonomy Handbook II stated that "[w]e found the largest proportion of educational objectives fell into this doinain." TAXONOMY HANDBOOK II, supra note 150, at 6; see also Calder, In the Cells of the 'Bloom Taxonomy,' 15 J. CurRiculum STUd. 291, 292 (1983) ("the essence of virtually every objective is cognitive").

176. See BLOOM's TAXONOMY, supra note 127 , at 18 , passim.

177. Blooin's understanding of the dynanic relationship between knowledge and cognitive skills anticipated recent research: "[o]ur general understanding of learning theory would seem to indicate that knowledge which is organized and related is better learned and retained than knowledge which is specific and isolated." Id. at 35.

178. Bloom's Taxonomy has been criticized as an insufficient description of the cognitive processes that failed to provide a comprehensive educational instruction in cognition and conceptual development. See generally Calder, supra note 175, at 300 ("The influence of the Bloom Taxonomy is set to wane over the next 25 years. Given an alternative classification of objectives geared to important content distinctions, and showing a better understanding of the nature of understanding, teachers will begin to question their allegiance to the Taxonomy."); Ennis, A Logical Basis for Measuring Critical Thinking Skills: Bloom's Taxonomy, Educ. LEADERSHIP, Oct. 1985, at 44, 45 (Bloom's Taxonomy is too vague for use in shaping "higher order" thinking skills); Furst, Bloom's Taxonomy of Educational Objectives for the Cognitive Domain: Philosophical and Educational Issues, 51 REv. EDUC. REs. 441, 446 (1981) ("The notion of a cumulative hierarchy . . . has provoked strong philosophical criticism of the taxonony.... [T] he linear assumption is suspect on general philosophical grounds."); Holleman, The Fourth Domain of Educational Objectives: Induction, 14 INSTRUCTIONAL SCI. 169, 173 (1985) ("Bloom's taxonomy does not provide for the classification of every goal that an educational program or system may set for its students"); Seddon, The Properties of Bloom's Taxonomy of Educational Objectives for the Cognitive Domain, 48 REv. EDUC. REs. 303, 320 (1978) ("[i]t seems unlikely that any single taxonomy will ever provide a means of universal perfect understanding with any population of educators").

However, the taxonomy should not be judged on its empirical validity but rather on its value as an indicator of the importance of conceptual development in the work of the schools. Bloom's Taxonomy has been and continues to be instrumental in guiding schools toward the establishment of cognitively oriented curricular goals. Subsequent work modifying, amplifying, or questioning Bloom's Taxonomy has increased rather than diminished the importance of cognitive development in schooling. Bloom's Taxonomy is relevant not merely for its usefulness in identifying and ordering cognitive skills, but prinarily because it helped school leaders accept a view of the work of the schools as cognitive development and the notion that this view was consistent with the schools' own understanding of their unission. 
tive terms and in a related system of mental skills. This recognition of cognitive goals enabled curriculum designers and teachers to move away from the traditional "read and recite" mentality and focus instead on the wide range of cognitive skills employed in the acquisition of knowledge. ${ }^{179}$ Thus, the most significant consequence of Bloom's Taxonomy was to shift schools' attention away from the recitation of knowledge, the lowest level of the taxonomy, toward higher-order cognitive skills. ${ }^{180}$ Bloom's Taxonomy laid the groundwork for the subsequent cognitive research that has illuminated our understanding of the learning process. ${ }^{181}$ The taxonomy has assisted the systematic teaching of cognitive skills and the development of an educational approach focusing on cognitive development. Progress has been made towards reform of educational practices so that instruction can develop the full range of children's cognitive skills. Bloom's Taxonomy has dramatically and profoundly shaped the way schools understand their educational mission, ${ }^{182}$ the structure and content of curricula, ${ }^{183}$ and the way teachers function

179. According to Bloom's Taxonomy, knowledge is the lowest level of cognitive operation, defined as "little more than the remembering of the idea or phenomenon in a form very close to that in which it was originally encountered." BLOOM's TAXONOMY, supra note 127, at 28-29. Bloom believed that "[b]ecause of the simplicity of teaching and evaluating knowledge, it is frequently emphasized as an educational objective out of all proportion to its usefulness or its relevance for the developinent of the individual." Id. at 34. He explained growth from basic knowledge to higherorder cognitive skills in terms of the individual's civic and social competence:

Clearly it is impossible to give the individual all the knowledge he will ever need for every new situation he will encounter. It is possible, however, to help him acquire that knowledge which has been found most useful in the past, and to help him develop those intellectual abilities and skills which will enable hiln to adapt that knowledge to the new situations.

... [We recognize] the individual's ability to independently attack his problems as a desirable sign of maturity. ... [U]nless the individual can do his own problem solving he cannot maintain his integrity as an independent personality.

Id. at 41 .

180. See, e.g., Paul, supra note 131, at 36 ("[a] generation of teachers" has been trained to engage students at the higher-level thinking skills of Bloom's Taxonomy).

181. See supra notes $128-72$ and accompanying text.

182. See Paul, supra note 131, at 36 ("It would be difficult to find a more influential work in education today than [Bloom's Taxonomy]."); see also Calder, supra note 175, at 291 (characterizing the power of the taxonomy over educators as a "spell"); Cole, A Common Focus for College Student Development, 17 C. STUDENT J. 212, 215 (1983) ("[t]hese educational objectives which are defined in a taxonomy of categorical terms have received wide acceptance and broad application in the field of education"); Seddon, supra note 178, at 303 ("[t] here is no doubt that [Bloom's Taxonomy] ... has had a considerable impact on educational thought and practice all over the world"); Travers, Taxonomies of Educational Objectives and Theories of Classification, EDUc. EVAluaTION \& POL'Y ANALYSIS, Mar.-Apr. 1980, at 5, 16-17 (taxonomy is used in most basic courses for training teachers, "who commonly view it as though it had the same place in thought about education that the periodic table has in relation to basic thought about chemistry").

183. See, e.g. Association of Teachers of Social Studies In THE CitY OF New York \& UNITEd Federation of Teachers, A HaNdBoOK for the Teaching of SOCIAL STUdies 4-8 (W. Dobkin, J. Fischer, B. Ludwig \& R. Koblinger 2d ed. 1985) (discussing curricular goals and objectives in terms of Bloom's Taxonomy). 
in the classroom. ${ }^{184}$

\section{State Curriculum Guides}

State education agencies and local school districts have incorporated many of Bloom's insights into their curriculum guides. For example, the New York, Missouri, and Washington guides, ${ }^{185}$ which reflect an understanding of the schools' work as the development of conceptual skills, call into question the Supreme Court's characterization of the educational mission of the schools in those states. Although a majority or near majority of the Court in Board of Education v. Pico, Bethel School District No. 403 v. Fraser, and Hazelwood School District v. Kuhlmeier characterized the educational objectives in these states as inculcative, the

184. For examples of the profound practical significance and near universal acceptance of Bloom's Taxonomy by teachers, see Beatty, Reading Comprehension Skills and Bloom's Taxonomy, 15 READING WORLD 101 (1975) (applying it to reading comprchension objectives); Clevenstine, $A$ Classification of the ISIS Program Using Bloom's Cognitive Taxonomy, 24 J. RES. SCI. TEACHING 699, 710-11 (1987) (recommending it to facilitate science instruction); Feezel, Toward a Confuent Taxonomy of Cognitive, Affective, and Psychomotor Abilities in Communication, 34 CoMm. EDuc. 1 (1985) (applying it to speech class activities); Furst, supra note 178, at $448-49$ (using it to assist with development of subject and curriculum goals, course descriptions, course and instruction planning, and test materials); Hamblen, An Art Criticism Questioning Strategy Within the Framework of Bloom's Taxonomy, STUD. ART EDUC., Fall 1984, at 41, 41-42 (using it to formulate a method for teaching art criticism); Johnson, Integrating Educational Theory and History, 10 HIST. TEACHER 425 (1977) (recommending it to history teachers); Kloss, Toward Asking the Right Questions: The Beautiful, the Pretty, and the Big Messy Ones, 61 CLEAR1Ng House 245, 246 (1988) (using it to formulate challenging questions that expand students' critical thinking); Martin, $A$ Checklist for Designing Instruction in the Affective Domain, EDuc. TECH., Aug. 1989, at 7 (using it to devise plan to guide teachers in affective domain instruction); Weller, The Teacher and Computerized Technology: A Teaching Partnership in the Cognitive and Affective Domain, 57 Clearing House 149, 150 (1983) (recommending use of computers to teach lower-level skills of knowledge and comprehension so that teachers can concentrate their efforts on teaching Bloom's higher-level skills); Wolverton, Conveying Music's Emotional Qualities, MusIC EduCATORS J., Jan. 1989, at 31, 33 (incorporating it into objeetives of music class).

185. I examined the curriculum guides (syllabi) of school districts involvcd in student speech cases that were considered to operate under the inculcative model of education by either a majority of Supreme Court Justices, for example in Fraser and Kuhlmeier, or by a substantial dissent, for example in Pico.

The New York guide is typical. It defines a syllabus as "a document stating the expected learning outcomes, including the goals, objectives, concepts, skills and understandings in a given subject." N.Y. COMP. CODES R. \& REGS. tit. viii, § 100.1(c) (1988). The introduction to the most recent social-studies syllabus spells out the role of the syllabus in the curriculum of the local schools:

This syllabus is meant to be used by school district administrators and teachers in developing their local social studies curriculum. The syllabus is a guide to curriculum development. It is a statcment of the goals and objectives of the State social studies program. It is not meant to offer day-to-day lesson plans. Rather, it should be uscd by administrators and teachers as a guide to the selection of strategies and materials to achieve these goals and objectives. Local and regional curriculum development efforts should be directed toward those ends while making adaptations which mcet local needs and goals.

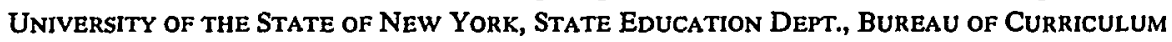
DEVElopment, Social Studies 11: UNITEd STATES History and Government 1 (tentative draft 1987) [hereinafter N.Y.S. UNITEd STATES History AND GovERNMENT SYLLABUS]. 
states' syllabi instead characterize the curricular goals of their socialstudies programs as the development of students' cognitive capacities.

The state-approved history syllabus in force in New York at the time of Board of Education v. Pico ${ }^{186}$ provides a good illustration of underlying conceptual-development goals. The eleventh-grade American History ${ }^{187}$ syllabus was orgamized into the categories of "concepts," "understandings," and "generalizations," each involving specific cognitive processes. ${ }^{188}$ A "concept," for example, was "a product of the analysis and synthesis of facts or experiences, rather than a definition to be learned."189 The reference to "analysis" and "synthesis," both ranked high in Bloom's Taxonomy, ${ }^{190}$ indicated utilization of higher-order cognitive skills. Moreover, this understanding of a "concept" integrated the learner's experiences in a inanner similar to the conceptual-development model because students attained the learning objectives, or curricular goals, through their own intellectual engagement with the curricular materials.

The other two categories of the history syllabus also promoted a model of learning similar to conceptual development. The "understanding" category required the student to do inore than learn a factual statement:

[U]nderstandings [were] goals to be reached, rather than stateinents to be copied, verbalized, and then forgotten. Pupils should be encouraged to go beyond the initial step of acquiring infornation, to venture intuitive speculations about meanings, implications, and consequences, to check hypotheses against available evidence, and to recognize the practical need at times for reaching pragmatic decisions without having all the facts. In this process, other understandings may be identified, im addition to the

186. For a discussion of Pico, see supra notes 47-64 and accompanying text.

187. I selected a history curriculum guide because of the connection between social studies and the state objective of maintaining a democratic political system. See supra note 53 and accompanying text. Until September, 1985, the regulations of the Commissioner of Education of New York required core courses to be taught in accordance with the approved state syllabi. See N.Y. CoMP. CoDES R. \& REgs. tit. viii, § 100.1(a) (repealed 1985). Because Grade 11 United States History was a required core course, history teachers had to abide by the curriculum. Id. The state syllabus set out state-approved goals and objectives for the course of study. See UNIVERSITY OF THE State of New York, State Education Dept., Bureau of Secondary Curriculum Development, Social Studies Grade 11: American History xiii-2 (1967 \& photo. reprint 1975) [hereinafter N.Y.S. AMERICAN HISTORY SyLLABUS]. The selection of specific teaching materials and daily course content, however, was left to educators on the local level. Id. at xiii, xvxvi.

188. N.Y.S. AMERICAN History SyllabUs, supra note 187, at xiv.

189. Id. A concept was also "constantly subject to expansion of meaning, and delineation of detail, as experience provides different settings and different relationships in new contexts." Id. This statement implies a dynamic and expansive quality to learning that is fundamentally at odds with the prescriptive, inculcative view of learning.

190. See supra note 176 and accompanying text (skill categories in Bloom's Taxonomy). 
ones stated by the syllabus writers. ${ }^{191}$

This approach to education encouraged students to develop concepts with their own cognitive powers rather than to passively accept the teacher's presentation of the state's conclusions. "Generalizations," the final category, also revealed the underlying conceptual nature of the educational approach - they were "offered for testing in future learning situations" 192 to promote students' critical thinking.

The most recent New York curriculum goals for the eleventh-grade United States History course continue to emphasize cognitive-related values and to associate critical thinking with civic values. ${ }^{193}$ Moreover, the state-approved evaluation instruments are also cognitive-related. The New York State Regents Examination in social studies not only measures specific knowledge but also assesses cognitive skills. ${ }^{194}$ Thus, New York's approach to teaching and testing is consistent with conceptual

191. N.Y.S. AMERICAN History Syllabus, supra note 187, at xiii-xiv.

192. Id. at Xv. In addition to offering certain generalizations, the syllabus directed that "[a]dditional generalizations should be identified by the teacher and the class." Id. at 10 .

193. See generally N.Y.S. UNITED STATES HISTORY AND GOVERNMENT SYLLABUS, supra note 185, at 1-24. The syllabus begins with ten "Goals of the Board of Regents for Elementary and Secondary Education in New York State," which include student mastering of communication skills such as "think[ing] logically and creatively" and "apply[ingl reasoning skills to issues and problems." Id. at 4. Snggested civic values include the "[u]nderstanding and acceptance of the values of justice, honesty, self-discipline, due process, equality and majority rule with respect for minority rights" and the "[a]bility to apply reasoning skills and the process of democratic government to resolve societal problems and disputes." Id. at 5. The Regents specify an approach to learning that is conducive to mature, effective citizenship: "Each student will develop a commitınent to lifetine learning with the capacity for undertaking new studies, synthesizing new knowledge and experience with the known, and refining the ability to judge." Id.

Following these overall social-studies goals, the syllabus lists specific social-studies skills to be taught. Its language contemplates granting students latitude in developing their own positions and conclusions, consistent with democratic education and conceptual development. See infra notes 218-29 and accompanying text. The syllabus also promotes citizenship competency. Its rationale is particularly illuminating: "While democracy does not depend on blind obedience, it does depend on informed assent to and, where necessary, expression of informed disagreement with rules and laws made by representatives. Informed assent requires the ability to know what the laws say and mean and to inake intelligent decisions." N.Y.S. UNITED STATES History AND GoverNMENT Syllabus, supra note 185, at 19. This rationale departs froin an inculcative position on educationit clearly contemplates diversity of expression, see, e.g., id. ("[s]tudents should learn, practice and apply [these skills] in acadeinic and real life situations"), which is not limited to a particular preselected curricular message. The content of the syllabus is framed in terms of "major ideas" that challenge student judgment rather than provide answers. For example, the first major idea presented under the topic "Decade of Change: 1960s" is that "Ir]acism is deeply imbedded in United States thought and traditions; this has made the black struggle for equality a long and difficult proeess." Id. at 90. Recall the introduction to this Article: a student said that George Washington owned slaves. New York's syllabus would place both the student's statement and the teacher's treatment of it within the proper bounds of classrooin discourse-they would not only be tolerated, but advocated by the state.

194. See, e.g., University of the State of New York, Regents High School Examination: Comprehensive Examination in Social Studies (administered Jan. 26, 1976) (on file with author) (questions require students to utilize higher-order thinking skills in addition to merely reciting their knowledge). 
development, giving learners substantial responsibility and opportunity to formulate their own conclusions througli a process that employs and develops cognitive skills. ${ }^{195}$

Similar curriculum guides developed in other states, whose educational goals have been described by the Court as inculcative, also reflect the view that education sliould promote conceptual development. ${ }^{196}$ While these guides support the fundamental notion that the schools intend to encourage essential democratic values, ${ }^{197}$ they also support the proposition that inculcative goals are subordinate to the learning objectives of conceptual development. ${ }^{198}$ The syllabi also indicate that students and teachers may bring their own ideas into the educational forum ${ }^{199}$ - they explicitly describe an educational process characterized

195. See supra notes $165-72$ and accompanying text (need for student expression in the development of student knowledge).

196. For example, the school goals in effect at the time of Hazelwood School Dist. v. Kuhlmeier, discussed supra notes 84-110 and accompanying text, are contained in HazElwOOD SCHOOL Districr, Social Studies MaNual (1974) [hereinafter Hazel wood Social Studies MaNual]. In this guide, the objectives for eighth-grade "United States History and Institutions" instruction included developing skills to: "[1] Formulate and test hypotheses based on an analysis of given information of factors involved.... [2] State possible solutions to problems facing the American society. ... [3] Examine a variety of viewpoints on issues before forming an opinion." Id. at 13-14.

There was no state curriculum guide for social studies in Washington at the time of Fraser, discussed supra notes 65-82 and accompanying text. However, the current guide contains higherorder thinking skills consistent with conccptual development. See SUPERINTENDENT of PuBLic Instruction, Washington State Dept. of Education, Soclal Studies Curriculum GuIdelines K-12 (1986) [hereinafter WaSH. State CuRRICulum Guidelines]. These guidelines are purely advisory in nature, meant to assist local school districts in developing their curricula, see id. at xi; Washington statutes require certain courses but do not specify the curricular objectives or content for these courses, see id. at xv-xvi (citing WASH. REV. CODE § 28a.05.060 (setting high school graduation requirements)). State administrative requirements are equally nonspecific. See id. at xv (citing WASH. ADMIN. CODE $§ 180-50-125$ (requiring Umited States history for high school graduation)). The social-studies curriculum guides are consistent with conceptual development throughout.

197. See Hazelwood Social Studies MaNual, supra note 196, at vi (contemplating not only instruction in democratic values but a corresponding "school environment which fosters the highest democratic ideals, respect for self and others, self-discipline, [and] an understanding of rights and responsibilities"); WASH. STATE CURRICULUM GUIDELINES, supra note 196, at 135 (adopting the position of the National Council for the Social Studies, which describes democratic values in broad terms and lists "justice, equality, responsibility, freedoin, diversity, and privacy as essential").

198. The Hazelwood School District had numerous noninculcative objectives under the goal of "Social Development." For example, "[t]he student will: . . . demonstrate ability to relate to and communicate with others by discussing ideas and views and by formulating or re-evaluating positions on the basis of diverse views ... [and] develop a value system based upon assessing past and present activities of man." Hazelwood Social Studies MANuAl, supra note 196, at i. The Washington curriculum guidelines also emphasized conceptual development, particularly in the area of critical thinking, by aiming to accomplish curricular goals through students' intellectual endeavors rather than any prescribed set of facts or ideas. See Wash. STATE CuRRICULuM GUIDELINES, supra note 196, at 71-73. These guidelines adopted the recommendations of the National Council for the Social Studies, which organize intellectual skills according to the categories of Bloom's Taxonomy. See id. at 144-46.

199. For example, the Hazelwood curriculum guide contained an elective course at the high school level entitled "Teenagers and the Law," which had cognitive objectives with particular 
by open discourse among teachers and students involving a wide variety of knowledge and ideas. Thus, the educational goals of the states are not confined to the inculcation of information or the regulation of student ideas or behavior. Rather, their syllabi reflect an interest in promoting student critical thinking within an expanding pool of ideas introduced by both the schools and their students.

\section{Falling Short of Their Cognitive Ideals: Why Schools May Prefer the Inculcative Model over Conceptual Development}

Schools' learning goals, which are described by the Supreme Court as inculcative, are inore appropriately characterized as emphasizing conceptual development. However, there is ample evidence that schools fall far short of their conceptual-development goals. ${ }^{200}$ Why do school administrators continue to pursue inculcative strategies despite the stated educational objectives of the schools? It appears that school officials adhere to the inculcative model essentially because of prevailing political, institutional, adınimistrative, and bureaucratic concerns rather than from sound educational practice.

First, school officials may find it easier to maintain their authority under an inculcative nodel of education. Authority is a concept ingramed within school systems, where admimistrators seek to maintain control over teachers and students, and teachers seek to maintain control over students. A cominon thread in the student-speech cases is school concern that student expression may bring about a collapse of discipline and the hierarchical authority of administrators and teachers. ${ }^{201}$

emphasis on higher-order thinking skills. The Hazelwood School District gave both students and teachers significant discretion to select subjects for classroom discussion under the school's educational directive to "[d]iscuss factual, public policy and moral value issues when deemed appropriate by the teacher and students. Hazelwood Social STUdies MANUAL, supra note 196, at 149 (emphasis added); see also WASH. STATE CURRICULUM GUIDELINES, supra note 196, at 146 (social-studies skills include the "personal skills" to "[e]xpress personal convictions" and "[c]ommunicate own beliefs, feelings and convictions").

200. See Karp, Why Johnny Can't Think: The Politics of Bad Schooling, HARPER's, June 1985, at 69-73. The author concludes that schools are not achieving their goals:

The great ambition professed by public school managers is, of course, education for citizenship and self-government, which harks back to Jefferson's historic call for "general education to enable every man to judge for himself what will secure or endanger his freedom." What the public schools practice with remorseless proficiency, however, is the prevention of citizenship and the stifling of self-government.

Id. at 70 .

201. Justice Black expressed fear of losing control of students in his dissent in Tinker: "I wish, therefore, wholly to disclaim any purpose on my part to hold that the Federal Constitution compels the teachers, parents, and elected school officials to surrender control of the American public school system to public school students." Tinker v. Des Moines Indep. Community School Dist., 393 U.S. 503, 526 (1969) (Black, J., dissenting); see also Levin, supra note 7, at 1668 ("[d]espite our rhetoric that the purpose of education is to impart to youth democratic values and political participation skills, however, the real purpose of education at times seems to be to create a passive, docile citizenry" (footnotes omitted)). 
Conducting school operations in an inculcative manner unay discourage some students from questioning the authoritative judgments of school officials. Inculcation corresponds to a hierarchical system of authority in which the prescribed curriculuin determines the educational worth or correctness of ideas. ${ }^{202}$ The conceptual-development model, in contrast, determines the worth of ideas by applying cogmitive skills to assess their value. In other words, in inculcative education an answer is correct when the teacher or textbook says so, whereas in conceptualdevelopinent education the correctness of an answer depends on the quality of the argument. The inculcative notion of education carries with it far less intellectual risk for adininistrators and teachers than does the conceptual approach. Under the mculcative unodel the prescribed curriculuin tends to be absolute and defined, so correctness is based on prescriptions rather than independent assessinent of worth. In contrast, the conceptual-development model tends to be process-oriented and relative, involving significant reference to student views and values and constantly questioning and assessing ideas contained within the school environinent as well as the authority for those ideas, including teacher opinions and textbooks.

Furthermore, the inculcative nodel may provide school officials with a rationalization for imposing their own arbitrary opimions on the rest of the school communty. In Bethel School District No. 403 v. Fraser, ${ }^{203}$ for exainple, school officials rejected an arguably correct interpretation of their rules that would have shielded Fraser from punishment, favoring instead an interpretation resting on the alleged inission of the school to instill values. ${ }^{204}$ The inculcative inodel thus allows school officials to claim that they are promoting democratic values, such as civility, when actually they are engaging im antidemocratic behavior, such as suppressing speech. ${ }^{205}$

A second reason why school officials may favor the inculcative model over the conceptual-development model is to avoid negative reactions from their two major political constituencies-the coinmunity and parents. Members of the community inay put pressure on school author-

202. See infra note 242 and accompanying text (students graded according to curricular prescriptions).

203. 478 U.S. 675 (1986). For a discussion of Fraser, see supra notes $68-83$ and accompanying text.

204. Compare Fraser, 478 U.S. at $678-79,686$ (school's rules gave Fraser ample notice that his speech might be sanctioned, and for purposes of due process, school rules need not be as detailed as criminal rules) with id. at 691-96 (Stevens, J., dissenting) (arguing that Fraser did not have adequate notice that his speech would be judged improper under the school's rules or by school authorities who reviewed his speech in draft).

205. See, e.g., id. at 681 (rationale stated for suppressing student speech was to inculcate "habits and manners of civility"). 
ities to either include or exclude ideas and values. ${ }^{206}$ As a result of this pressure, school officials may wish to follow the inculcative model of education, which allows them to exercise tight control over the content of speech occurring in the schools. Inculcation thus enables schools to avoid potential controversy arising from objectionable student expression by suppressing the expression. The ability to suppress speech would be particularly important to schools in situations in which it would be difficult to justify or explain the educational purposes of the speech being questioned by community members. ${ }^{207}$

Parents niay express concern over student expression for similar yet even more substantial reasons: parents may wish to prevent their children from bemg exposed to values and ideas that the parents deem disagreeable, and they are as likely as school authorities to be challenged by children who have discovered independent thinking at school. Parents who feel threatened by these potential challenges may prefer greater school control over their children. ${ }^{208}$ The conceptual-developnient model's cultivation of independent thinking would undermme this parental desire for control. Furthermore, parents inay neither appreciate the educational value of conceptual development nor desire their children to think independently. To avoid potential conflicts with the wishes of parents, school officials may reject a cognitive in favor of an inculcative model, which affords them greater control over students. ${ }^{209}$

A third explanation for schools' continued use of the inculcative model is simply that it is easier to inculcate than to develop cognitive skills. $^{210}$ Contrary to the view that progressive education is soniehow

206. The notion that certain expression is disagreeable to some members of the community runs throughout the first amendment education cases. See, e.g., Meyer v. Nebraska, 262 U.S. 390 (1923). In Meyer, the state passed legislation attempting to prohibit the teaching of foreign languages to students below the ninth grade. The impetus for the legislation appeared to be animus against German immigrants. The Court repudiated the idea that a state might conduct its schools to "foster a homogeneous people." Id. at 402 .

207. The Kuhlmeier opinion comes close to recognizing the importance of allowing schools to control potentially controversial speech that may be viewed as having school approval. The Court granted school authorities wide discretion over speech in school-sponsored activities "that students, parents, and members of the public might reasonably perceive to bear the imprimatur of the school." Hazelwood School Dist. v. Kuhlmeier, 484 U.S. 260, 271 (1988).

208. An assessment of parents' desires to control their children is beyond the scope of this Article; nevertheless, it should be mentioned that research indicates that sometime during the elementary school years, peers overtake parents and schools as the primary influence on the child. See J. Goodlad, A Place Called School $39-43$ (1984).

209. On the other hand, instead of submitting to pressure from the community and parents, school authorities should consider the importance of educating the community and parents about the merits of conceptual development. By taking advantage of opportunities for contact with parents and community members, schools may be able to justify the edueational validity of the conceptual model.

210. See Bloom's Taxonomy, supra note 127, at 34 ("Because of the simplicity of teaching and evaluating knowledge, it is frequently emphasized as an educational objective out of all proportion to its usefulness .... [T] he teacher and school tend to look where the light is brightest 
permissive or loosely structured, ${ }^{211}$ cognitive instruction, particularly at higher levels, requires substantial plannimg and preparation. When compared to the inculcation inethod of feeding students information from a textbook, the effort required for a teacher to orchestrate opportumities for student learning under the cognitive model is considerable. ${ }^{212}$

Fourth, schools may prefer inculcation because it allows thein to present allegedly curricular grounds for suppressing student speech while concealing their bias against the suppressed ideas. In Searcey v. Har$r i s^{213}$ the Eleventh Circuit recognized the potential for such bias in the justifications presented by the school board for limiting the speech of a group that was criticizing the military's access to the school's "Career Day." The court noted that "avoiding debate about controversial matters, although facially reasonable, is capable of concealing bias," allowing the board to suppress certain viewpoints of which it did not approve. ${ }^{214}$

One final explanation for the schools' einphasis on a pedagogy more "suited to an autocratic society"215 may be that American society is largely autocratic and that the educational process sensibly supports this systein. ${ }^{216}$ In other words, the educational product, rather than being inconsistent with schools' objectives, is instead consistent with the real nature of our society. If this reason for the schools' pursuit of inculcation is true, it falls considerably short of our democratic ideals. ${ }^{217}$

and where it is least difficult to develop the individual."); Glaser, supra note 136 (advances in cognitive science underscore the complexity of the learning process that teachers must master); Accommodation of a Scientific Conception, supra note 167 (effecting a conceptual change in students requires considerable educational knowledge and skill).

211. See Hafen, Hazelwood School District and the Role of First Amendment Institutions, 1988 DUKE L.J. 685, 700-01 (using examples of unsuccessful cognitive imstruction to convey the view that such instruction involves little rigor).

212. [I]nstruction is a much more complex process when access [to knowledge] is the goal.

This type of teaching requires more knowledge and skill on the part of teachers than is currently the norm. ... [T] hose who teach for access must possess considerable subject matter and pedagogical expertise. If students are to develop networks of knowledge, teachers need a firm grasp of the most important ideas in each of the subject matter areas they teach. ... . They should know how to foster various learning-to-learn strategies, and how to equip students with sufficient metacognition so that they can exercise judgnient about the use of those strategies.

Prawat, supra note 148, at 34; see generally V. JonEs \& L. JoNES, CoMPrehensive Classroom Management: Creating Positive Learning Environments 252-301 (2d ed. 1986) (describing various approaches to planning and teaching lessons at higher cognitive levels that actively involve students).

213. 888 F.2d 1314 (11th Cir. 1989).

214. Id. at 1325 .

215. J. Dewey \& E. Dewey, Schools of TOMORRow 218 (1915) [hereinafter Schools of TOMORRow]. For a further discussion of Dewey's theory of education, see infra notes 219-22 and accompanying text.

216. See Karp, supra note 200, at 73 (failure of American education to develop widespread academic, cognitive, or civic competence not accidental, but intentional on part of elites, who are a menace to truly republican education).

217. This view is consistent with a Marxian analysis of education. In a consumption-based, class-dominated capitalist society, inhibiting citizens' cognitive abilities and promoting inculcation 


\section{Conceptual Development Promotes Democratic Education}

The highly influential philosophy of democratic education expounded by John Dewey and recently reconsidered and expanded by Professor Amy Gutmann ${ }^{218}$ decisively rejects the inculcative model of education in favor of a theory of learning that promotes conceptual development. Dewey's theory of education recognized the fundamental role that education plays in a democratically governed society. ${ }^{219}$ Dewey strongly beheved that certain approaches to education were more conducive to and consistent with the cultivation of democratic values than others. ${ }^{220}$ In line with this thesis, he argued that the notion of education as the inculcation of values and ideas has serious shortcomings:

The conventional type of education which trains children to docility and obedience, to the careful performance of imposed tasks because they are imposed, regardless of where they lead, is suited to an autocratic society. ... But in a democracy [these traits] interfere with the successful conduct of society and governinent. ... If we train our children to take orders, to do things simply because they are told to, and fail to give them confidence to act and think for themselves, we are putting an almost insurmountable obstacle in the way of overcoming the present defects of our system and of establishing the truth of deinocratic ideals. . . Children in school inust be allowed freedom so that they will know what its use ineans when they becoine the controlling body, and they must be allowed to develop active qualities of initiative, independence, and resourcefulness, before the abuses and failures of democracy will disappear. ${ }^{221}$

Thus, Dewey beheved that schools ought to focus on developing students' abilities to think in order to effectively teach them democratic values. ${ }^{222}$

perpetuates nonrational consumption and class distinctions. See Gintis \& Bowles, The Contradictions of Liberal Educational Reform, in WORK, TECHNOLOGY, AND EDUCATION: Dissenting EsSays in the Intellectual Foundations of American Education 92, 133 (W. Feinberg \& H. Rosemont, Jr. eds. 1975) ("[t]he predominant economic function of schools involves not the production or identification of cognitive abilities but the accreditation of future workers as well as the selection and generation of noncognitive personality attributes rewarded by the economic system").

218. "In Democratic Education, Gutmann recxamines the terrain traversed by Dewey. Her book is perhaps the finest contribution to the literature on democratic education of the last seventy years." Yudof, Book Review, 99 ETHics 439, 440 (1989) (reviewing A. GuTMANN, Democratic Education (1987)). For a further discussion of Gutmann's work, see infra notes 223-26 and accompanying text, and Sherry, Book Review, 66 Tex. L. Rev. 1229 (1988) (reviewing A. GutManN, Democratic Education (1987)).

219. See J. DEWEY, DEMOCRACY AND EduCATION 152-63 (1966) [hereinafter DemocracY AND EDUCATION]; SCHOOLS OF TOMORROW, supra note 215, at 303.04.

220. See Democracy AND EdUCATION, supra note 219, at 152-63; SchoOls of TOMORROW, supra note 215 , at 303-04.

221. Schools OF TOMORROW, supra note 215, at 303-04.

222. See Democracy AND EDucAtion, supra note 219, at 152 . Dewey was ahead of his time in advocating a model of education founded on principles of conceptual development, believing that 
In her recent book Democratic Education, ${ }^{223}$ Professor Amy Gutmann elaborates on Dewey's behef that educators in a democratic educational system should provide students with the capacity to think for themselves by nurturing an environment in which students participate. Gutmann sees education in a deınocracy as having two functions. First, education should prepare students to participate in society's "good life," both in terms of values (that is, assessing and choosing among permissible alternatives) and in terms of capability (that is, attaining the competence to be productive in those alternatives). Second, education should prepare students for effective participation in democratic political life by developing their capacity for rational dehiberation. ${ }^{224}$

The critical questions in delnocratic education focus on the content and inethod of the educational process-and on who controls it. Gutmann believes that education in a democratic state is chiefly concerned witl providing young people with the means for recognizmg and choosing from alternative good hives, while distinguishing these good lives from unacceptable alternatives.

A denocratic state is therefore committed to allocating educational authority in such a way as to provide its members with an education adequate to participating in democratic politics, to choosing among (a limited range of) good lives, and to sharing in the several subcommunities, such as families, that impart identity to the lives of its citizens. ${ }^{225}$

Thus, the key to democratic education is providing students with the ability for rational and critical deliberation. Gutmann suggests that limited political and parental autlority over the education process provides students the opportunity to acquire this ability. ${ }^{226}$

"the sole direct path to enduring improvement in the methods of instruction and learning consists in centering upon the conditions which exact, promote, and test thinking." Id. at 153. In addition, he believed that

no thought, no idea, can possibly be conveyed as an idea from one person to another. When it is told, it is, to the one to whom it is told, another given fact, not an idea. The communication may stimulate the other person to realize the question for himself and to think out a hike idea, or it may smother his intellectual interest and suppress his dawning effort at thought. But what he directly gets cannot be an idea. Only by wrestling with the conditions of the problem at first hand, seeking and finding his own way out, does he think .... If he cannot devise his own solution (not of course in isolation, but in correspondence with the teacher and other pupils) and find his own way out he will not learn, not even if he can recite some correct answer with one hundred per cent accuracy.

Id. at $159-60$.

223. A. Gutmann, Democratic Education (1987).

224. Id. at 49-52. "[C]hildren must be taught enough to participate intelligently as adults in the political processes that shape their society." Id. at xi.

225. Id. at 42.

226. In order to protect the formative process of critical deliberation among children, Gutmann argues that two "principled limits" over parental and state authority are necessary: nonrepression and nondiscrimination. "The principle of nonrepression prevents the state, and any group within it, from using education to restrict rational deliberation of competing conceptions of the good life and the good society" and is "compatible with the use of education to inculcate those character traits, 
In contrast to conceptual development, inculcative education is essentially antithetical to democratic education because it does not provide students with the capabilities for critical deliberation that are necessary in a democratic society. ${ }^{227}$ Rather, an understanding of the work of the schools as conceptual development is more consonant with and supportive of preparing students for democratic citizenship. ${ }^{228}$ The conceptual-development model enhances students' intellectual skills for the necessary critical deliberations. ${ }^{229}$ Therefore, conceptual development

such as honesty, religious toleration, and mutual respect for persons, that serve as foundations for rational deliberation of differing ways of life." Id. at 44 . Nondiscrimination reinforces the logic of nonrepression by voiding the exclusion of entire groups of children and by supporting student deliberation among different conceptions. Id. at 45 .

227. The inculcative understanding of education is deficient for four reasons. First, it fails to comport with the cognitive manner in which students actually learn. See supra notes 128-72 and accompanying text (describing conceptual-development model).

Second, inculcation may compel adherence to government-prescribed values and ideas beyond the legitimate scope of government power. Dean Yudof raises the question "When does government education and persuasion become, to use pejorative words, unconstitutional government indoctrination and coercion?" Yudof, supra note 97, at 677. His answer is that government exceeds the scope of its function when it "threaten[s] the system of freedom of expression," as it would with "the establishment of a "pall of orthodoxy." Id. at 694-95. Under inculcation, students are not rewarded for expressing the ideas or values they think or believe but rather for reciting required materials.

Third, the mculeative method of teaching is contrary to the democratic values intended to be taught. Inculcation teaches students to recitẹ rather than to evaluate. But a fundamental ingredient of democracy is an informed citizenry capable of arriving at its own conclusions. See A. GuTMANN, supra note 223, at 46 (democratic education develops capacity for rational deliberation and for evaluating alternative ways of life); see also Sunstein, Beyond the Republican Revival, 97 YALE L.J. $1539,1547-51$ (1988) (asserting that civic republicanism is characterized by deliberation). Students should be given the chance to assess the school's curriculum so that they can begin to realize and practice their emerging democratic competencc. The inculcative notion of education disserves the democratic values it pretends to promote. See Levin, supra note 7, at 1649 (undemocratic educational practices may undermine democratic educational goals).

Finally, inculcative education "is not an effective way to produce the desired attitudes, beliefs, and dispositions in students." Van Geel, supra note 146, at 263; see also id. at 262.89 (questioning desirability and effectiveness of inculcating students to achieve governmental goals of promoting values, preparing youth for citizenship, and fostering loyalty and patriotism); supra notes 145.64 and accompanying text (schools eannot compel students to adopt values through inculcation).

228. For example, a recent report from the National Commission on Social Studies in the Schools, after acknowledging an inculcative function of education, described the ultimate goal of social-studies education in terms of fostering effective citizenship in a manner consistent with conceptual development and rational deliberation:

The understanding and transmission of citizenship, or "civic virtue," has been a continuing responsibility of the schools, and particularly of social studies. We believe that good citizenship is not just a matter of the observance of outward forms, transmitted from the old to the young, but also a matter of reasoned conviction, the end result of people thinking for themselves.

National, Comm'n on Social Studies in the Schools, Charting a Course: Social Studies FOR THE 21ST CENTURY Xi (1989).

229. Under the conceptual-development model of education, students develop the capacity for critical thought by reformulating their views on the information and ideas to which they are exposed in school and by utilizing higher-order cognitive processes. Gutmann views the development of higher-order cognitive skills as vital to students' attainment of rational deliberation: 
contributes to democratic education because it establishes a learning process involving constructive participation of the learner, which is analogous to civic participation and deliberation within a democratic government.

III

IMPLICATIONS OF THE WORK OF THE SCHOOLS AS

CONCEPTUAL DEVElopmENT: EXPANSIVE STUDENT FREEDOM OF EXPRESSION

A primary purpose of education, as espoused by scliool autliorities and educators, is to develop young people's capacities to function effectively in society in a manner consistent with the principles of democratic governinent. $^{230}$ This purpose inevitably involves the schools in the socialization of young people in certain values and ideas that the state may legitinately determine. ${ }^{231}$ Thus, schools necessarily have the power to establish a curriculum and to commuincate their curricular messages to their students. ${ }^{232}$ The question that remains is the degree to which schools ought to be required, both constitutionally and as a matter of educational policy, to allow students to express ideas that do not coincide with the schools' curricular messages. ${ }^{233}$

As Part I indicated, school authorities assert the power to limit student expression in the scliools so that it conforms to the schools' curricu-

[C]hildren will eventually need the capacity for rational deliberation to make hard choices in situations where habits and authorities do not supply clear or consistent guidance. These two facts about our hives-that we disagree about what is good and that we face hard choices as individuals even when we agree as a group-are the basis for an argument that primary education should be both exemplary and didactic. Children must learn not just to behave in accordance with authority but to think critically about authority if they are to live up to the democratic ideal of sharing political sovereignty as citizens.

A. GUTMANN, supra note 223 , at 51 .

Democratic participation requires citizens to be able to make political decisions based on informed judgments, which requires advanced conceptual development. When informed decisions must be made, information alone is insufficient for citizens to assert their democratic voice-the capacity to assess that information is necessary for effective democracy. Thus, democratic participation is fundamentally an application of cognitive skills. It follows that schools' tolerance of student expression in furtherance of conceptual development, see supra notes 165-72 and accompanying text, coincides with and promotes the democratic values and deliberative skills essential for effective democratic participation.

230. See supra notes $218-29$ and accompanying text (discussing the theory of education as preparation for democratic participation).

231. See supra notes $22-23$ and accompanying text; see also Board of Educ. v. Pico, 457 U.S. 853,864 (1982) (both states and local school boards must be permitted discretion in order to establish a curriculum that instills values and ethics in students); cases cited supra note 23 (asserting schools' authority to instill values).

232. The terms "curriculum" and "curricular message" are defined at supra note 1. For an example of curricular ideas and values, see the discussion of the New York State social-studies syllabus at supra note 193 and accompanying text.

233. Schools are free to provide greater tolerance for student speech than the Constitution requires, of course, and may do so as a matter of educational policy. 
lar messages. This authority to suppress speech derives from the power to inculcate values. ${ }^{234}$ Part II described the conceptual-development model of instruction, which more accurately describes the schools' educational mission than does the inculcation-of-values inodel. This Part argues that the more appropriate conceptual-development inodel of education necessitates greater protection of student expression than the Supreme Court currently recognizes.

\section{A. Freedom of Expression Is Necessary for Students' Conceptual Development: The Cognitive Classroom}

\section{The Value of Freedom of Expression in Schools}

The learning process requires much more than thinking-schooling also entails extensive histening, speaking, reading, and writing in which ideas are advanced, exchanged, and evaluated. Schooling should provide students with opportunities to engage in higher cognitive operations because students cannot be expected to function at such levels unless they have the opportunity to eniploy higher operations in practice.

Expression is instruniental to the developinent of cognitive structures and higher-order cognitive skills. ${ }^{235}$ Free student expression facilitates and enhances the development of cognitive structures and proinotes conceptual developinent both in the highly personal sense of formulating one's own thoughts and in the inore public sense of articulating ideas and viewpoints. Indeed, first amendinent freedoin of speech is grounded in part on the notion that freedom of expression is essential to the development of the human personahty:

The achievement of self-realization commences with development of the mind. But the process of conscious thought by its very nature can have no limits. An individual can neither tell where it may lead nor anticipate its end. Moreover, it is an individual process. Every man is influenced by his fellows, dead and hiving, but his mind is his own and its functioning is necessarily an individual affair.

From this it follows that every man-in the developinent of his own personality - has the right to form his own beliefs and opinions. And it also follows that he has the right to express these beliefs and opinions. Otherwise they are of little account. For expression is an integral part of the development of ideas, of mental exploration and of the affirmation of self. $^{236}$

Freedom of speech necessarily includes the freedom to express one's ideas despite their unpopularity. As the learning model of conceptual

234. See supra notes 46-123 and accompanying text (Supreme Court views the schools' work as inculcation of values).

235. See supra notes 165-72 and accompanying text (importance of student expression in learning).

236. T. Emerson, TOWARd a General Theory of the First AMENDMent 4-5 (1966). 
development recognizes, student thinking about any particular matter may be quite different from the official curricular viewpoimt. Thus, student expression, which ranges from formative and tentative ideas to conclusions and beliefs, is also likely to differ or diverge from official curricular views. ${ }^{237}$ The central thesis of this Article is that the ability of students to fully engage their cognitive capacities is enhanced when they are free to express their own thoughts, even though these thoughts may at times differ from the prescribed curriculum. Indeed, because of the individual nature of learning, students should be expected to express ideas and conclusions that diverge from official viewpoints and to cite ideas and experiences derived from sources outside the schools' prescribed curriculum. It is iromic that open discussion, which is discouraged under prescriptive methods of teaching, may be more effective in attaining school objectives than direct attempts at inculcation through methods such as lecture. ${ }^{238}$

Moreover, students' conceptual development would be threatened if

237. For example, the views of students and school authorities may differ as to the importance of George Washington's ownership of slaves. See supra note 2 and accompanying text.

238. An example of a subject that inculcative education would restrict but conceptualdevelopinent education would tolerate is whether inarijuana should be legalized. Presumably, the school's curricular message is that marijuana should be illegal (and that students should not sinoke it). Under Kuhlmeier, school authorities could prohibit a lesson in which students would advocate the legalization of marijuana: "A school must also retain the authority to refuse to sponsor student speech that inight reasonably be perceived to advocate drug . . . use . ..." Hazelwood School Dist. v. Kuhlmeier, 484 U.S. 260, 272 (1988). Under the conceptual-development model, however, student debate would be encouraged in order to advance students' substantive knowledge and cognitive abilities. The process and outcome of such a debate is described in G. JoHNSON \& $R$. Hunter, Action Research Project, University of Colorado, Juvenile Justice and Delinquency Prevention Council, Using School-Based Programs to Improve Students' CITIZENSHIP IN COLORAdO: A RePORT to Colorado Educators (1987). A Colorado junior high school teacher in law-related education (LRE) directed students in small groups to

research thoroughly and prepare for debate by the class a legislative bill on a topic of their choice. Froin a list of 20 categories, one group in each section of LRE chose marijuana legislation. After a library search, the students listed as inany pro and con facts as they could find pertaining to use and control of the substance. Following discussion within groups of the fact sheets, each student wrote a one-page essay on his or her own position and each group prepared two essays-one in favor of legislation and one opposing it. The essays were critiqued in writing by students working on unrelated topics. Then each group prepared a draft of a bill for "discussion in cominittee," the committee being one of the other groups. Finally, the class at large sat as meinbers of the state legislature and debated the bill. In both LRE sections, students decided overwheliningly that the arguments against marijuana use and in favor of its control were inore persuasive than the counterarguinents.

Id. at 19. Self-evaluations before and after the debate by students both in the LRE classes and in similar non-LRE classes showed that "the per student decline in inarijuana use [for the LRE students discussing marijuana legislation] was the largest obtained in any LRE program." Id. Johnson and Hunter attributed the effectiveness of the class to the following factors:

The teacher denied taking a heavy hand in any of this process, other than inaking the initial open-ended assignment. Students perceived (correctly) that the topic chosen, arguinents developed, and conclusions reached all came from them. That perception probably made the exercise far inore effective than any series of sermon-like "temperance 
their curriculum-related expression was restricted by school prescriptions. As students develop knowledge and cognitive skills, moving from novice to higher levels of intellectual competence, ${ }^{239}$ their understanding and ability will obviously need further development. Schooling, then, is practice for adult life. While practicing, students will often fall short of intended goals by misunderstanding, misapplymg, inaccurately analyzmg, poorly creatimg, and erroneously evaluating the subject matter on which they are working. If they are to derive benefit from this practice, students must be able to make errors without fear of punishment or detriment. Schools must therefore have some tolerance for error-and for student speech-when teaching students how to think critically.

\section{The Conceptual-Development Classroom}

The capacity to accommodate student expression is the key difference between the conceptual-development and the inculcation-of-values models of education. In broad terms, the inculcative classroom is primarily prescriptive while the conceptual-development classroom is largely deliberative. This difference is illustrated by the way each views the origniation, development, and assessment of ideas within the curriculum.

In the mculcative model, instructional ideas are prescribed, developed, and validated in terms of the curriculum. ${ }^{240}$ The Supreme Court adopts this view when it describes mculcative teaching as a one-way

lectures" from adults could have been. The teacher now faces the challenge of repeating the process deliberately without robbing it of its spontaneity.

Id. The school's curricular message, which opposed marijuana use, was clearly presented to and evaluated by the class. That the contrary view was also expressed did not diminish the school's inessage- to the contrary, the students in the LRE classes acquired more knowledge by learning on their own terms and through their own efforts than they would have through an inculcative approach. Additionally, the LRE students gained a lesson in effective citizenship.

239. See, e.g., Glaser, supra note 20 , at 22 ("there are Inany crucial and identifiable intermediary phases of learning between initial performance and the attainment of counpetent and expert performance").

240. Walter Karp reviewed eight recent books on American education and described the evaluation of student knowledge as highly inculcative:

From the first grade to the twelfth, from one coast to the other, instruction in America's classrooms is almost entirely dogmatic. Answers are "right" and answers are "wrong," but mostly answers are short. "At all levels, [teacher-made] tests called almost exclusivcly for short answers and recall of information," reports Goodlad. In more than 1,000 classrooms visited by his researchers, "only rarely" was there "evidence to suggest instruction likely to go much beyond mere possession of information to a level of understanding its implications." Goodlad goes on to note that "the intellectual terrain is laid out by the teacher. The paths for walking through it are largely predetermined by the teacher." The give-and-take of genuine discussion is conspicuously absent. "Not even 1\%" of instructional time, he found, was devoted to discussions that "required some kind of open response involving reasoning or perhaps an opinion from students. ... The extraordinary degree of student passivity stands out."

Karp, supra note 200 , at 70. 
transmission from teacher to student. ${ }^{241}$ Student communication is qualitatively limited to recitation of the school's relatively concrete curricular message. This model attributes little value to student expression:

Throughout the school year, the teacher, after attempting to convey to the students the required version of a particular subject, tests them to see if they have learned the material properly. Answers conforming to the view taught in the class get high marks, while mconsistent views may get low marks. ${ }^{242}$

Little or no value is accorded to student-generated ideas that diverge from the highly prescriptive curriculum, whicl establishes a concrete set of desired facts and norms. Student knowledge of tliese facts and norms is the primary end of instruction. Under the Fraser/Kuhlmeier approacli, schools may "disassociate" themselves from and express disapproval of divergent views by either suppressing ${ }^{243}$ or punishing speech. $^{244}$

In contrast, the conceptual-development model views the curriculum in terms of the origination, development, and assessment of ideas

241. For example, in Ambach v. Norwick, 441 U.S. 68 (1979), the Court described the role of teachers without any recognition of a need to respond to students: "[T] eachers by necessity have wide discretion over the way the course material is communicated to students. They are responsible for presenting and explaining the subject matter in a way that is both comprehensible and inspiring." Id. at 78 (emphasis added). See also Hazelwood School Dist. v. Kuhlmeier, 484 U.S. 260, 271 (1988) ("[e]ducators are entitled to exercise greater control over [curriculum-related] student expression to assure that participants learn whatever lessons the activity is designed to teach"); Tinker v. Des Moines Indep. Community School Dist., 393 U.S. 503, 522 (1969) (Black, J., dissenting) (teacher's job is to "teach subjects" that are part of the school's "selected curriculum" because "[t]he original idea of schools, which I do not believe is yet abandoned as worthless or out of date, was that children had not yet reached the point of experience and wisdom which enabled them to teach all of their elders"). Justice Black's Tinker dissent was cited with approval by the majorities in both Fraser and Kuhlmeier. See supra note 100. For examples of Chief Justice Rehnquist's understanding of inculcative education, see supra note 62 .

242. Diamond, The First Amendment and Public Schools: The Case Against Judicial Intervention, 59 TEX. L. REv. 477, 497 (1981). Professor Diamond described the process of inculcating the curriculum in the classroom as follows:

[E]lected representatives of the state designate the ideology and some of the content of public school teaching material. The elected representatives of the locality, the local school board, and their appointees designate the remainder of the content and much of the ideology. The board, the principals, and the teachers may select a textbook favoring their own views and ideologies, and they might not permit alternatives. The teacher may be required to submit in advance a series of lesson plans reviewed by the higher authorities in order to control the shape, content, and methodology of the teacher's classes. . . . In the end, a sufficient compilation of proper responses to the controlled process produces a graduate. Thus, from one point of view, the public schools embody in all their aspects the denial of first amendment rights.

Id.

243. See Kuhlmeier, 484 U.S. at 263-64 (constitutional for school to delete school newspaper articles deemed inappropriate by school's principal).

244. See Bethel School Dist. No. 403 v. Fraser, 478 U.S. 675, 678-79 (1986) (student suspended and disqualified as candidate for graduation speaker because of sexually suggestive nominating speech); Poling v. Murphy, 872 F.2d 757, 760 (6th Cir. 1989) (student declared ineligible for student government because of improper campaign speech), cert. denied, $110 \mathrm{~S}$. Ct. 723 (1990). 
that accommodate both the school's curricular messages and the students' contributions. The school's voice is not the only one heard ${ }^{245}$ while the school estabhishes curricular goals and objectives, these goals contemplate student input into their specific formulation. ${ }^{246}$ The students' role in the learning process is to examine the curricular propositions as much as it is to recite them, and throughout this process students are invited to contribute their own ideas. ${ }^{247}$ The classroom is characterized by student-teacher interaction, a give and take, that produces the dynamic nature of quality education. ${ }^{248}$ Ideas are both announced and interchanged-they proceed not only from teacher to student but also from student to teacher and student to student. In addition to the recitation of facts, students are involved in other intellectual processes such as application, analysis, synthesis, and evaluation. ${ }^{249}$

Of course, teachers can directly convey the school's curricular message to the students. ${ }^{250}$ But they do far more than that: The teacher is not only the soloist, but the conductor and a member of the orchestra as well. The teacher of conceptual development is just as concerned with engaging and assisting students in the coinprehension of the material on their own as in telling the students what they should know or in requiring the "correct" answers from them. The conceptual-development model views the curricular content as both specific, in terms of required knowledge, and general, with a primary emphasis on cognitive skills. ${ }^{251}$ Because facts are treated both as ends and as means under the concep-

245. Conceptual development supports commentators opposed to a school monopoly on ideas: the "antipropaganda principle" of Professor Buss, see Buss, supra note 7, at 541-42 (proposing a limit on the school's power to restrict the range of ideas available to students through curricular propaganda); the "multidimensional model" of education of Professor Robert Keiter, see Keiter, supra note 16, at 52-55, 59-60 (suggesting, as an alternative to inculcation, a model of education that reflects the varied individual and community interests affected by public schools); and Dean Mark Yudof's theory that freedom of expression may protect individuals from excessive government speech (at least in the schools), see Yudof, When Governments Speak: Toward a Theory of Government Expression and the First Amendment, 57 TEX. L. REV. 863, 873-97 (1979) (arguing that governmental communications may negatively affect freedom of expression by isolating captive audiences from contrary influences).

246. See, e.g., supra notes $186-99$ and accompanying text (outlining New York's conceptual development goals).

247. See supra notes $165-72$ and accompanying text.

248. See supra note 212 and accompanying text (describing the complexity of the teacher's function in promoting conceptual development).

249. See Bloom's TAXONOMY, supra note 127, at 186-93; see also supra note 176 and aceompanying text (mental skills in Bloom's Taxonomy).

250. See, e.g., Prawat, supra note 148, at 5-8 (contrasting presentations of ideas as effective teaching strategies for direct conveyance of knowledge); $c f$. V. JONES \& L. JONES, supra note 212, at 252 ("students leam best when teachers actively engage them by asking questions, [and] expecting responses"). The most effective direct instruction, however, involves teachers providing "instructional input" and "modeling" of correct learning, as well as students' getting involved in both guided and independent practice. See id. at 252-54.

251. See supra note 193; infra note 329. 
tual-development model, curricular ideas become less absolute and more relative in form than under the inculcative inodel..$^{252}$ Thus, the assessment of the value or validity of student ideas is a complex process, requiring teachers to examine students on levels higher than their inere ability to recall facts. ${ }^{253}$

In significant ways, the cognitive classroom resembles the townmeeting inodel used by Professor Meiklejohn to elucidate the parameters of freedom of speech. ${ }^{254}$ In the town meeting, the full value of freedom of speech is attained only through structured regulation. Rules for the orderly presentation and discussion of ideas are, therefore, established. For example, a moderator is appointed and discourse is limited to germane subjects. It is necessary that, "so far as time allows, all facts and interests relevant to the problem shall be fully and fairly presented to the meeting," and in order to accomplish this, "[w] hat is essential is not that everyone shall speak, but that everything worth saying shall be said."25s The objectives of self-government require that citizens be able to voice and hear any and every point of view because they "must pass judgment" ${ }^{256}$ on their worth.

The classroom is hikewise subject to regulation. ${ }^{257}$ However, unlike the participants in a town meeting, who are presumed to be competent decisionmakers, students at the precollege level are not wholly free to pass judgnient on the worth of ideas. The schools' objectives do not regard students as having attaimed either their full autonomy of citizenship or mastery of any subject. Schools teach selected viewpoints and values and support the processes of critical thinking and rational deliber-

252. See V. Jones \& L. Jones, supra note 212 , at $252-54$.

253. See generally Snow, supra note 138 (issues and examples of assessment for new conceptions of learning).

254. A. Meiklejohn, Political Freedom: The Constitutional Powers of the People $24-28$ (1960) (arguing that limits must be placed on speech to facilitate frec discussion of issues).

255. Id. at 26.

256. Id. at 27.

257. In his Fraser dissent, Justice Stevens recoguized the need for regulation in the classroom: "I believe a school faculty must regulate the content as well as the style of student speech in carrying out its educational mission." Bethel School Dist. No. 403 v. Fraser, 478 U.S. 675, 691 (1986) (Stevens, J., dissenting). He went on to state that " "[a]ny student of history who has been reprimanded for talking about the World Series during a class discussion of the First Amendment knows that it is incorrect to state that a "time, place, or manner restriction may not be based upon either the content or subject matter of speech." '" Id. at 691 n.l (Stevens, J., dissenting) (quoting Consolidated Edison Co. v. Public Serv. Comm'n, 447 U.S. 530, $544-45$ (1980) (Stevens, J., concurring) (quoting Consolidated Edison Co. v. Public Serv. Comm'n, 447 U.S. 530, 536 (1980))).

Unlike the marketplace model, the conceptual-development model does not open the school up to every idea or require the school to provide competing or alternative ideas to its prescribed curriculum. The precollege educational process is not involved in promotion of political choice or advancement of trnth, which are the foundations of the marketplace model. Rather, the rationale for protected speech in the conceptual-development model derives from the notion of self-realization, which at the precollege level has less to do with specific outcomes of knowledge or values than with developing students' abilities to determine these outcomes for themselves upon adulthood. 
ation that help students become effective and productive future citizens. Because students are still developing, their school-related expression is tempered by the prescribed curriculum. Schools may have the power, due to their curricular authority, to decide whether student speech is germane and to regulate it according to such factors as sound academic standards. But under the precepts of conceptual development, students still maintam interests of their own in the present realization of their intellectual capacities.

The relevant basis for a distmction between speech that the schools should incorporate into the learning process and speech that they should exclude ought to be the schools' capacity to supervise the speech instructionally. ${ }^{258}$ While conceptual development involves students in the formulation of their own understanding of the material, this process occurs under the guidance and direction of the teacher. Under the Tinker standard, the teacher supervises and controls any student-created offensiveness in the classroom directed at other students ${ }^{259}$ or student speech inappropriate to the class's level of maturity ${ }^{260}$ or disruptive to the curriculum. ${ }^{261}$ When speech falls short of disruption but nonetheless conflicts with or contradicts the school's intended message or lesson, ${ }^{262}$ the teacher can correct inaccuracies, provide additional ideas to offset the divergent view, model proper forms of expression or behavior, or appropriately censure speech that fails to meet the school's standard of propriety.

The Tinker conception of the classroom as both "ordained" and

258. Schools can more readily supervise curriculum-related student speech in a classroom than in other, more public, school locations. Justice Brennan recognized this in his Fraser concurrence, making a distinction between speech at a high school assembly and at other locations in the school: "[Fraser's] speech may well have been protected had he given it in school but under different circumstances." Fraser, 478 U.S. at 689 (Brennan, J., concurring). Brennan, however, believed those circumstances to be "where the school's legitimate interests in teaching and maintaining civil public discourse were less weighty." Id. (Brennan, J., concurring). In contrast, the argument advanced here is not that the school's interests are less weighty in the classroom, but that the classroom provides a greater opportunity to utilize divergent speech, in this case Fraser's "offensive" campaign speech, to educational advantage by discussing its pros and cons. Furthermore, the educational harm of divergent speech in a classroom can be mitigated by the supervising teacher, who, being directly involved with the students, can better judge the appropriateness of their speech and act accordingly. See infra text accompanying notes 259-62.

259. This teacher mediation of viewpoints is necessary under the Tinker standard. See supra notes 36-42 and accompanying text.

260. By indicating that Fraser's speech was inappropriate for immature students, the Fraser Court implied that such speech might be appropriate for more mature students. See Fraser, 478 U.S. at 683 .

261. See Tinker v. Des Moines Indep. Community School Dist., 393 U.S. 503, 513 (1969) ("conduct by the student, in class or out of it, which . . . materially disrupts classwork ... is ... not immunized").

262. See infra notes $266-309$ and accompanying text (advocating protection of divergent student speech). 
"supervised"263 thus provides the framework for reconciling curricular objectives with divergent student speech. According to this view, a school passes through two phases of instruction: first, ordaining a curriculuin through the establishinent of curricular goals and content, and second, supervising student academic developnient towards those curricular goals and related objectives. The school's curricular message is a coinponent of the school's ordained curriculum, and inculcation of this message is a favored metliod of attaining curricular goals and commumicating curricular content. However, student responses to the curricular message as well as original student contributions constitute the second dinnension of the instructional process. During this phase, teachers in their supervisory roles inanage the developmental aspects of student learning.

In other words, the classroom plays a dual role in achieving the goal of helping students attain both desired knowledge and cognitive skills: it is coininuricator of the school's curricular inessage and mediator between that message and the students' own ideas. Tinker clearly conteniplated the possibility that students, under the supervision of their teacher, would engage in the discussion of ideas not endorsed by the school because even unendorsed ideas are relevant to the school's work. $^{264}$ This notion runs counter to the Kuhlmeier view that facultymember supervision of student speech indicates the school's endorseinent or sponsorship. ${ }^{265}$

\section{B. Student Speech That Diverges from the Prescribed Curriculum Interferes Little with the Work of the Schools}

As a general proposition, the first amendment does not forbid the state to inpose himits that reasonably restrict the time, place, or manner of speech in foruins such as schools. ${ }^{266}$ Reasonableness depends on the relationship between the restricted speech and the normal activities of

263. Tinker, 393 U.S. at 512.

264. See id. at 512-13 (schools' activities necessarily include student communication of ideas not paralleling those in the curriculum).

265. One of the factors that the Court found persuasive for determining school sponsorship was teacher supervision. See Hazelwood School Dist. v. Kuhlmeier, 484 U.S. 260, 268 (1988). The question in that case was whether the newspaper qualified as a curricular activity under specified school policy. In dicta, however, the Court extended its reasoning in this case to cover "expressive activities." The Court held that "[t]hese activities may fairly be characterized as part of the school curriculum, whether or not they occur in a traditional classroom setting, so long as they are supervised by faculty members and designed to impart particular knowledge or skills to student participants and audiences." Id. at 271 (emphasis added).

266. See, e.g., Grayned v. City of Rockford, 408 U.S. 104, 115 (1972) (government can restrict protected speech in public places using reasonable time, place, and manner regulations related to compatibility of the speech activity with the normal function of the site). However, the Grayned Court referred to Tinker's recognition of special circumstances in schools with respect to determining normal speech activities and to the material or substantial interference test that Tinker used to determine compatibility with ordinary speech activity. Id. at 118-19. 
the place in which it occurs. Tinker applied this requirement to schools by asking whether the restricted speech was reasonably consistent with the "special characteristics of the school environment."267 The Tinker Court, consistent with the conceptual-development model of education, would permit student speech that does not materially or substantially interfere with or disrupt the work of the schools, thereby appropriately and sufficiently accommodating both student and school speech interests. The later Fraser/Kuhlmeier approach-“"[a] school need not tolerate student speech that is imconsistent with its "basic educational mission" "268 differs hittle from the Tinker standard on its surface. However, because the Fraser/Kuhlmeier Courts understood the mission of the schools as the inculcation of values, the "reasonable restriction" standard allows schools to provide hittle room for student speech that diverges from the schools' curricular hines. ${ }^{269}$ Because inculcative education does not accommodate divergent speech, it is not "unreasonable" for schools to suppress such speech.

Thus, whether a school's regulation of student speech comports with the first amendment depends on what is meant by the "work" or the "basic mission" of the school. The understanding of a school's work dictates the treatment of speech. When the work of the school is understood as conceptual development, student speech that diminishes the effectiveness of the school's curricular message can still fall short of interfering or being inconsistent with the school's curriculum. ${ }^{270}$ The work of the school has a broader and considerably more flexible objective than inculcating any particular message. ${ }^{271}$ The school's curricular message is one means for accomplishing a curricular objective, but not necessarily the exclusive means or even an objective in itself, and student speech consisting of student messages regarding curricular matters is also an important component of the curriculum. ${ }^{272}$ In contrast, when schooling

267. Tinker, 393 U.S. at 506.

268. Kuhlmeier, 484 U.S. at 266 (quoting Bethel School Dist. No. 403 v. Fraser, 478 U.S. 675, 685 (1986)).

269. See supra notes 65-97 and accompanying text (discussing the Fraser and Kuhlmeier opinions).

270. Emphasizing conceptual development does not diminish the school's ability to attain its curricular goals, particularly with respect to the "fundamental values necessary to the maintenance of a democratic political system." Ambach v. Norwick, 441 U.S. 68, 77 (1979) (upholding statute denying permanent teaching certificates to noncitizen teachers). Cognitive research demonstrates that student knowledge improves as a result of educational practices consistent with conceptual development. See, e.g., Prawat, supra note 148, at 34 (outlining the knowledge and pedagogical skills needed to encourage greater conceptual development).

271. See supra notes $188-99$ and accompanying text (describing the characteristics of a conceptual development curriculum).

272. Morcover, equating the curricular message with the curriculum fails to recognize the important distinction between teaching and learning. Essentially, teaching encompasses what the school does, while learning pertains to what the student does. In schooling, teaching and learning 
is understood as inculcation there is little distinction between the message and the curriculum. The students are expected to learn just what the school teaches, ${ }^{273}$ leaving the school with hittle tolerance for divergent speech.

There are three categories of student speech relative to schools' curricular messages: speech supportive of or consistent with the curricular message, speech that disrupts or interferes with this message, and speech that contradicts or diverges from this message. We can assume schools will not suppress student expression in the first category, speech that supports or coincides with the schools' curricular messages. The other categories, however, are more problematic.

With respect to the second category of disruptive student speech, schools properly have the power to restrict student speech that materially and substantially interferes with the work of the schools or that involves substantial disruption or invasion of the rights of others. ${ }^{274}$ The way in which the schools understand their work is critical because the determination of when himitations on speech are permissible depends on the offensive quality of the speech relative to the work of the schools. If that work is highly prescriptive, a school's capacity for tolerating divergent student speech is likely to be relatively low. ${ }^{275}$ In other words, student speech would not have to diverge inuch from the curriculum before the school would view it as disruptive. ${ }^{276}$ On the other hand, when the work of the school is understood as conceptual development, the school would expect, and might even encourage, divergent student expression. Therefore, a school practicing conceptual development would have a greater capacity to tolerate such divergent speech. ${ }^{277}$ This increased tolerance could extend to student speech that has both disruptive and educationally valuable qualities. ${ }^{278} \mathrm{~A}$ school recognizing that disruptive speech may nevertheless have educational value could find the speech to be compatible with its work. ${ }^{279}$ By allowing the educational value of potentially disruptive speech, a school practicing the conceptual-development

form a dynamic and interdependent process, in which one cannot successfully take place without the other.

273. For an elaboration of the inculcative understanding of education, see supra notes $240-42$ and accompanying text.

274. See Tinker v. Des Moines Indep. Community School Dist., 393 U.S. 503, 513 (1969).

275. See supra notes $240-42$ and accompanying text (discussing inculcative education).

276. During the district court hearing of Fraser, "both the principal . . . and the assistant principal . . testified that in their view the word 'inappropriate' was synonymous with the word 'disruptive' in the school context." Fraser v. Bethel School Dist. No. 403, 755 F.2d 1356, 1361 (9th Cir. 1985), rev'd, 478 U.S. 675 (1986).

277. For examples of school curricula that comport with this idea, see supra notes 186-99 and accompanying text (descriptions of various state curriculum guides); infra note 329 .

278. For an example of divergent student speech with educational value, see the discussion of $O O^{\prime}$ Connor, infra notes 328-63 and accompanying text.

279. For an example of the Ninth Circuit's giving weight to the educational function of student 
method of education would in effect reclassify "disruptive" student speech as merely "divergent."

The third category of student expression is the most problematic in terms of regulation and protection. This category of speech falls between speech that is consistent with the school's curricular message and that which imterferes with the school's work. It is expression that would neither be endorsed by the school nor excludable under the Tinker standard as disruptive of the school's work or harmful to individual students. This is precisely the area of speech that was at issue in Bethel School District No. 403 v. Fraser 280 and Hazelwood School District v. Kuhlmeier. ${ }^{281}$ Under the Fraser/Kuhlmeier approach, this category of student expression is evaluated according to its relationship to pedagogical objectives. ${ }^{282}$ This standard of evaluation contemplates only two types of student speech: that which is either "tolerated" or "promoted" by the school. Tolerated speech encompasses "a student's personal expression that happens to occur on the school premises"283 and includes "personal intercommunication among the students."284 Promoted speech is equated with school-endorsed speech or expression that "may fairly be characterized as part of the school curriculum."285 Both Fraser and Kuhlmeier indicate that student speech arising in the classrooin is curriculum-related, classifying this type of speech as that which the school inay be considered to proinote. ${ }^{286}$

Because Fraser and Kuhlmeier characterized education as inculcative and did not consider its developinental function, their treatinent of student speech is invalid in the conceptual-developinent context. The Court in Kuhlmeier identified three reasons that entitle the school "to exercise greater control"287 over student curriculuin-related speech: the school is to "assure that participants learn whatever lessons the activity is designed to teach, that readers or listeners are not exposed to inaterial that inay be inappropriate for their level of maturity, and that the views of the individual speaker are not erroneously attributed to the school."288

freedom of expression, see Fraser v. Bethel School Dist. No. 403, 755 F.2d 1356 (9th Cir. 1985), rev'd, 478 U.S. 675 (1986).

280. 478 U.S. 675 (1986).

281. 484 U.S. 260 (1988).

282. See supra note 99 and accompanying text.

283. Kuhlmeier, 484 U.S. at 271.

284. Tinker v. Des Moines Indep. Community School Dist., 393 U.S. 503, 512 (1969).

285. Kuhlmeier, 484 U.S. at 271.

286. "A high school assembly or classroom is no place for a sexually explicit monologue ....." Fraser, 478 U.S. at 685 (emphasis added). "These activities may fairly be characterized as part of the school curriculum, whether or not they occur in a traditional classroom setting, so long as they are supervised by faculty members and designed to impart particular knowledge or skills to student participants and audiences." Kuhlmeier, 484 U.S. at 271 (emphasis added).

287. Kuhlmeier, 484 U.S. at 271.

288. Id. 
The rationale underlying each of these reasons fails under conceptualdevelopment analysis.

The first Kuhlmeier objective- "to assure that participants learn whatever lessons the activity is designed to teach"289 -is invalid in the conceptual-developinent context because the school cannot guarantee that students will learn or accept the curricular inessage. Students construct new knowledge in light of their preexisting knowledge base and cognitive structures, inuch of which are derived froin outside the school's domain. ${ }^{290}$ In other words, the Court's stated interest-that students learn the school's lesson-overstates the school's practical power and ability to effectively impart its lesson. A school clearly has the legal power to present its curricular inessages and to have them received and attended to without interference. ${ }^{291}$ The school can also require students to repeat its inessages to indicate that they have been received. In addition, the school may have the power to require students to conform their behavior to school prescriptions. ${ }^{292}$ The school cannot, however, compel students to personally value or beheve the school's prescribed ideas. ${ }^{293}$ The legal authority of the school to prefer certain ideas over others and to teach these ideas to students should not justify excluding studentoffered ideas inerely because they differ froin the preferred curriculum. No one would suggest that wrong or ungrammatical answers should be forbidden. The school's proper function is to discover where students deviate from the lesson and to redirect thein appropriately. Nonharmful and inoffensive student ideas should be treated likewise. To require students to adhere to curricular prescriptions without a discussion of alternative viewpoints would short-circuit the conceptual-developinent process. $^{294}$

The second Kuhlmeier interest-protecting students from speech beyond their level of maturity-becoines less significant under the con-

289. Id.

290. See supra notes $145-64$ and accompanying text (explaining students' control over the lessons they learn).

291. See Buss, supra note 7 , at 516-22 (student speech intercepting and contradicting the school's curricular message).

292. See Bethel School Dist. No. 403 v. Fraser, 478 U.S. 675, 683 (1986).

293. See TAXoNOMY HANDBooK II, supra note 150, at 139-40 (student progresses from merely receiving the school's message to valuing it, and this valuing depends on student acceptance of the value, an individual matter based largely on factors outside the school); see also supra notes 161-64 and 245 and accompanying text.

294. Inappropriate ideas are always an instructional concern of the school. However, the function of the school is not to ban or punish inappropriate, nonharmful student ideas, but rather to provide students with a framework for these ideas in agreement with sound educational and conceptual-development practices. This intermediate category of inappropriate yet nonharmful speech serves an important educational function as "imperfect" or "correctable" knowledge. When such speech is not disruptive of the educational process it is essential to it because such speech provides both students and teachers the opportunity to assess its worth. 
ceptual-development model. Students who are approaching adulthood should be recognized as increasingly capable of coping with materials from which they will receive no protection as adults. Although very young children may not be "ready for rational dehberation," older children "become responsive" and need practice in rational deliberation to become participants in democratic society. ${ }^{295}$ The state-established curriculum guides reviewed in this Article specifically contemplate students progressing through stages of knowledge and coguitive ability corresponding to their experience and maturity. This progression culminates at the high school level, where students are able to engage contemporary, controversial issues and make up their own minds about them. ${ }^{296}$ Moreover, the Tinker standard provides ample protection from nonspeculative harm to student sensibilities. ${ }^{297}$

The third criterion-to assure that student views are not erroneously attributed to the school-may impede students' conceptual development to the extent that it permits schools to proscribe controversial ideas raised by students. Whether speech is attributable to the school or amounts to the school's curricular message can be determined with reference to two factors: first, the speech's reliance on the school's resources, as Kuhlmeier estabhished in the case of a school newspaper ${ }^{298}$ and Fraser noted in the case of a school assembly; ${ }^{299}$ and second, the function of the speech in the school curriculum, with specific reference to the asserted curricular objectives of the state and school district. ${ }^{300}$ In contrast to the Kuhlmeier analysis, which is grounded in the mculcative theory of education, the conceptual-development model anticipates that students will be exploring issues, examining facts and materials, and voicing opinions that may be at odds with those held by other members of the community. ${ }^{301}$ Schools should acknowledge that student viewpoints will be

295. A. GUTMANN, supra note 223 , at 50-51.

296. See, e.g, infra note 329 (citing "Participation in Government" class as example in which students are encouraged to debate relevant but controversial local issues).

297. See Tinker v. Des Moines Indep. Community School Dist., 393 U.S 503, 508 (1969) (speech in school might not be protected if it "intrudes upon ... the rights of other students"); see also Bethel School Dist. No. 403 v. Fraser, 478 U.S. 675, 687-90 (1986) (Brennan, J., concurring) (sexual innuendo that school officials determined was not appropriate for a high school assembly was sufficiently disruptive to remove it from protection under Tinker).

298. Hazelwood School Dist. v. Kuhlmeier, 484 U.S. 260, 267-70 (1988).

299. Fraser, 478 U.S. at 687-90.

300. See Searcey v. Harris, 888 F.2d 1314, 1324-25 (11th Cir. 1989) (examining stated sclool board policies and regulations to determine whether limitations on student speech constituted viewpoint discrimination). Neither Fraser nor Kuhlmeier addressed this second function.

301. See, e.g., University of The State of New York, State Education Dept., Bureau of Curriculum Development, Soclal Studies 12: Participation in Government 30 (tentative draft n.d.) [hereinafter N.Y.S. Participation in Government Syllanus] ("Participation in Government poses a challenge to the school administration and local community ... risking the possibility that students may pursue issues that may be sensitive"). 
expressed in connection with the learning process. While a school may not endorse particular viewpoints that students may hold or voice, the school should endorse the process of learning in which these opinions are expressed and recognize that student speech merely contradicting the school's message is a legitiniate part of the school curriculum. ${ }^{302}$ When the speech in question falls short of disrupting the school's work or harming other individuals, the student should not be penalized for holding a view about which another might complain. The soundness of this contention becomes clear when one recognizes that a central theme of democratic education is to cultivate tolerance for dissent and different views within the realm of nondisruptive or nonharmful ideas. ${ }^{303}$

Tolerance of nondisruptive or nonharmful student expression under the conceptual-development paradigm does not constrain the state from communicating its own curricular message. ${ }^{304}$ Students will generally not reject the set of knowledge, skills, and values that schools wish to convey to the next generation. ${ }^{305}$ Moreover, the conceptual-development model of education does not unduly restrict school programs: schools can still appropriately deal with speech that is "ungramniatical, poorly written, inadequately researched, biased or prejudiced, vulgar or profane, or unsuitable for immature audiences" ${ }^{306}$ by disassociating themselves from such student expression. In addition, conceptual developinent does not prevent schools from setting "high standards"307 for student speech-for example, offensive speech without educational value can be appropriately excluded under the Tinker standard. ${ }^{308}$ Finally, while instruction that focuses on conceptual development promotes freedom of

302. Because the divergent speech is not seen as incorrect, but rather as a correctable stage in the student's developmental process, the school will associate itself with the speech by incorporating it into the learning process and responding to it instructionally. In other words, the school would be teaching a subjeet without teaching it "as true." See Epperson v. Arkansas, 393 U.S. 97, 111 (1968) (Black, J., concurring). Under this reasoning, the school could disapprove of student viewpoints that either contradicted the approved curricular message or were disapproved of by the school, yet associate itself with the speech as an integral component of the appropriate educational process, thereby allowing students to engage and advance their conceptual development. See supra text accompanying notes 235-39 (discussing the need for student expression in the learning process).

303. See, e.g., A. GuTManN, supra note 223 , at 50-52.

304. See Buss, supra note 7, at 506 (schools can inculcate values neeessary for democracy while encouraging commitment to freedom by allowing diverse viewpoints).

305. But see Tinker v. Des Moines Indep. Community School Dist., 393 U.S. 503, 524-25 (1969) (Black, J., dissenting) (suggesting that students may, in fact, reject the values promoted by the school through engaging in protest-oriented and disruptive expression).

306. Hazelwood School Dist. v. Kuhlmeier, 484 U.S. 260, 271 (1988).

307. Id. at 271-72.

308. See Tinker, 393 U.S. at 509 (speech that substantially interferes with the schools' work can be restricted upon proper notice and a showing of disruption). Note, however, that the Court in Kuhlmeier suggested that the Tinker standard need not be met when a school "disassociate[s] itself" from student speech that is "ungrammatical, poorly written, inadequately researched, biased or prejudiced, vulgar or profane, or unsuitable for immature audiences." Kuhlmeier, 484 U.S. at 271. 
expression, it does not imply relaxation of discipline, rejection of schoolpromoted values and ideas, or a system resulting in educational anarchy or cliaos. ${ }^{309}$

It would not be easy for schools to stand up for the conceptualdevelopment ideal of tolerating unpopular or disagreeable, but not disruptive, speech. Schools that do so may be required to implement some form of public education, undertake a leadership role in the community, and display courage. If scliools allow unpopular or controversial ideas that arise in the course of students' development to be censored, however, the process of conceptual developinent itself will be stifled.

\section{Conceptual Development and Judicial Deference}

Understanding the work of the schools as conceptual development significantly affects the amount of deference courts should give to schoolauthority determinations that student speech disrupts the schools' work. Under the conceptual-developinent model, student speech that conflicts with the school's inessage may nevertheless have educational value. However, current court deference standards, based on the inculcative inodel of education, are insufficient to provide adequate protection to speecl that is educationally valuable altlough distinct from the school's message. For example, the notion of judicial deference adhered to in cases such as Kuhlmeier permits school authorities to exercise broad discretionary judgment in restricting and punishing student speech. The Kuhlmeier standard permitting judicial intervention only when the restrictive action of school authorities "has no valid educational purpose" 310 does not provide sufficient first amendinent protection to expression that lias legitimate educational value and is consistent with the work of the schools.

In addition to its tendency to exclude educationally valuable student speecl, the inculcative model of teaching also contradicts first ainendinent values underlying democratic education for two reasons. First, the failure of a scliool to act in accordance witl its espoused first amendment values when it suppresses student speech creates a dissonance between the school's declared doctrine and its actual educational practice. This

309. While many pedagogical methods for developing cognitive skills involve more interaction among students than the old-fashioned read-and-recite methods, many others involve conventional student and teacher tasks that lend stability to the classroom environment. For example, much instruction under the conceptual-development model involves quiet work by students at their seats with appropriate monitoring and feedback. Reading, writing, and problem-solving are conducted in a manner similar to what one would expect in an inculcative classroom, with the exception that the purpose and intellectual content of the activities are substantially different. See Good, Classroom Research: A Decade of Progress, 18 Educ. Psychologist 127 (1983) (concluding that classroom management is effective with active learning approaches).

310. Kuhlmeier, 484 U.S. at 273. 
inconsistency is particularly destructive to first amendment values because students are not merely deprived of the opportunity to learn these values through their own firsthand experience of them-students may also come to doubt the integrity of first amendment principles as well as of the school.

In deferring to educators in their apphication of constitutional protections, courts should do more than just leave education to school authorities who "know best." Rather, courts have a responsibility to see that first amendinent values are mamtained in the exercise of government functions that may threaten them. While the authority to assess the educational suitability of school-sponsored or curriculum-related speech "properly rests with the school board"311 and the delegated school authorities, courts should evaluate such school-administration decisions in the context of the work of the schools that these authorities strive to uphold. ${ }^{312}$ Review of restrictions of student speech is particularly necessary because schools are charged with teaching respect for democratic values, including first amendment values. ${ }^{313}$ Therefore, courts have a responsibility to see that first amendment values are maintained when school boards evaluate the educational suitability of student speech because such evaluations may threaten the very values that schools have a duty to teach.

The second problem with court deference to school authorities under the inculcative model arises because the work or mission of the schools is determined in a process mvolving public participation. Parents, teachers, and state and local officials have a right to collaborate in and contribute to this process. ${ }^{314}$ For example, the curricular revision of the New York social-studies syllabus was accomphished through a process involving input from many sources: surveys of school districts, regional conferences, discussion papers, proposed and revised frameworks, a State Regents' action plan, draft syllabi, and extensive

311. Bethel School Dist. No. 403 v. Fraser, 478 U.S. 675, 683 (1986).

312. Thus, judges should look to the schools' definitions of their work in state and local currieulum syllabi and hold school authorities to the standards in these syllabi.

313. For example, the New York social-studies syllabus for the eleventh grade sets out the following democratic values:

The principles of a democratic system should serve as organizing ideas for the social studies program and for student learning. The development of civic values consistent with life in a democratic system is an overriding goal of the entire program. The values at the base of our democratic system include justice, a belief in the dignity of the individual, responsibility of the individual to others and to the community, rule by the will of the majority with respect for the rights of the minority, respect for the rights of others, appreciation of the achievements of diverse cultures and individuals and participation of all persons in government. In dealing with the specifics of the syllabus and in planning the curriculum which implements it, the development of these values should be a constant goal.

N.Y.S. UNITED STATES History AND GOVERNMENT SYLlabUS, supra note 185, at 1.

314. See Kuhlmeier, 484 U.S. at 273. 
field testing in the schools. This initial process took place over a sevenyear period and resulted in a tentative syllabus. ${ }^{315}$ Professional educators then played major roles in the development of the curriculum and produced materials that were reviewed by interested groups and the public. ${ }^{316}$ This exercise of civic participation constitutes the essence of the denocratic process in public education and contributes to public education at least as much as the election of school-board members. ${ }^{317}$ Thus in fashioning a deference standard, the courts must be cognizant of the fact that a judicial rule permitting local school authorities to censor student expression on the basis of one particular educational objective may threaten larger policies that were derived from a collaborative, denocratic effort.

Furthermore, courts should consider avoiding broad deference to the decisions of school authorities because school boards may not be as democratically sound as they niay appear. Local school boards have often been criticized as unrepresentative of the community. ${ }^{318}$ At the other extreme, school boards may be overly sensitive to community pressures, responding either to strong but narrow interests or to majorities. ${ }^{319}$ Consequently, the countermajoritarian protections of the Bill of Rights may not be adequately safeguarded if the actions of school boards are not subject to judicial scrutiny. ${ }^{320}$

When the mission of the schools is properly understood as conceptual development, the current practice of deferring primarily to the judgnient of school authorities in student-speech rights cases appears inconsistent with sound educational theory and practice. When evaluat-

315. See, e.g., N.Y.S. UNITED STATES HISTORY AND GOVERNMENT SYLLABUS, supra note 185 , at iii-x ("The total number of people who participated in some way [in the revision process] is in the thousands.").

316. Id.

317. Cf. Board of Educ. v. Pico, 457 U.S. 853, 891 (1982) (Burger, C.J., dissenting) ("[i]f the parents disagree with the educational decisions of the school board, they can take steps to remove the board members from office"). Much more is involved in democratic participation than merely going to the polls to express approval or disapproval of an individual. See Sunstein, supra note 227 (importance of citizen participation during deliberative decisionmaking in local political arenas).

318. See, e.g., Keiter, supra note 16, at 56 (factors such as low voter turnouts, uncontested candidates, and influential interest groups produce local scliool boards whose policies are not representative of their communities' sentiments).

319. See Ingber, supra note 7, at 37-39 (representative nature of elected scliool boards, which makes them highly responsive to the majority that voted for them, militates against allowing their unrestricted control over curricular decisions).

320. See West Va. State Bd. of Educ. v. Barnette, 319 U.S. 624, 637 (1943) (rejecting contention that interference witl the functions of local, county, and state school officers "would in effect make [the Court] the school board for the country' " (quoting Minersville School Dist. v. Gobitis, 310 U.S. 586, 598 (1940)). Barnette grounded its decision on countermajoritarian principles: "The very purpose of a Bill of Rights was to withdraw certain subjects from the vieissitudes of political controversy, to place them beyond the reacl of majorities and officials and to establish them as legal principles...."Id. at 638 . 
ing these cases, courts should undertake an examination of state and local educational requirements and practices, as well as expert testimony, to determine whether the speech conflicts with the work of the schools. The Tinker "material and substantial interference" rule is an appropriate standard to judge the suppression of speech by school authorities in the context of the schools' mission. This standard compels school authorities to justify their actions by proving that student speech reached a certain level of interference with the school's lesson. In addition, the educational harm that the authorities seek to prevent must be more than "undifferentiated fear"321 of such harm. One of the chief problems in the Fraser case was the lack of evidence supporting the school's main assertion that other students took Fraser's speech to be a lesson in appropriate civil discourse. $^{322}$ In light of the educational value of student speech, schools

321. Tinker v. Des Moines Indep. Community School Dist., 393 U.S. 503, 508 (1969).

322. In Fraser both the school and the Court appear to have been more concerned with Fraser's challenge to school authority than with the possibility they claimed-that Fraser's speech had a negative impact on the teaching of democratic discourse. Fraser's speech in front of the school's student body and teachers, while intentionally relying on sexual innuendo for its effect, was arguably permissible within the letter of the school rules. See Bethel School Dist. No. 403 v. Fraser, 478 U.S. 675, 691-96 (1986) (Stevens, J., dissenting). It is noteworthy that the complaints received by the principal were from teachers, not froin students. Id. at 678 . Even if these teachers were offended by Fraser's language, the speech as directed to them was protected under ordinary first amendinent doctrine. It is more plausible to assume that they were concerned with the effect on student discipline if the school did not, or legally could not, pumish Fraser-if Fraser were to "get away with it."

Regardless of the intentions underlying its actions, the real lesson taught by the school's disciplinary measures in Fraser was that while students are expected to engage in civil discourse, school authorities are not. Rather than teach "habits and manners of civility," id. at 681 , by the "slow and easily neglected route" of instruction and example, Barnette, 319 U.S. at 631 (footnote omitted), the school preferred to coerce student compkance through the threat of suspension and denial of educational opportumity. The pumishunent meted out by the school, removing Fraser's name from the ballot for graduation speaker and then prohibiting him from speaking after he was elected by write-in votes, see Fraser v. Bethel School Dist. No. 403, 755 F.2d 1356, 1357-58 (9th Cir. 1985), rev'd, 478 U.S. 675 (1986), went beyond the scope of the school's announced disciplinary procedures. Fraser eventually won an imjunction in federal district court, due to violation of his due process and first amendment rights, and was allowed to give his graduation speech. Fraser, 755 F.2d at 1358. Because the school's punishment was enjoined, its validity was never adjudicated by the Supreme Court due to mootness. See Bethel School District No. 403 v. Fraser, 478 U.S. 675, 686 (1986). In its majority opinion, however, the Court was not straightforward in its discassion of the school's mooted violation of Fraser's due process rights and presented the facts to minimize the proven fact of violation.

A bawdy speech arguably within school rules that goes unpunished due to the school's adherence to legal principles does not necessarily teach the student body to disobey authority. In fact, restraint by the school is less detrimental to student obedience than arbitrary methods of punishment, which violate the school's own stated disciplinary procedures. The crux of Fraser's complaint was not that he had been punished for the content of his speech-which was admittedly in poor taste- but to the excessive nature of the punishment. The Court was not persuaded, see Fraser, 478 U.S. at 686 (" $[t]$ wo days' suspension from school does not rise to the level of a penal sanction calling for the full panoply of procedural due process protections applicable to a criminal prosecution") and upheld the school's power to punish in the manner it did. The Court grounded this power in the schools' authority, or obligation, to inculcate habits and manners of civility in the 
should be obliged to provide substantial reasons for their decisions to restrict it.

Student speech that may potentially be construed as the school's message, ${ }^{323}$ yet which conflicts with the school's curricular message, is protected by the first amendment and should be permitted so long as three conditions are met. First, there must be a substantial connection between the speech and the learning objectives of the school activity in which it takes place. This provides appropriate weight to the value of student speech in the school. Second, the student speech must not intercept the school's curricular message and prevent it from reaching its intended audience ${ }^{324}$ nor be construed as the school's message. ${ }^{325}$ That speech takes place in connection with a school activity should be insufficient to demonstrate that the speech is, or may be perceived to be, endorsed or promoted by the school. ${ }^{326}$ Third, the student speech must

students. Id. at 681 . Unfortunately, the school showed itself capable of violating Fraser's due process rights, one of the essential values of our democracy. Getting students to understand the concept of due process is more essential to their participation in a democracy than merely inculcating thein with value-laden notions of civility.

If the school and the complaining teachers were really interested in teaching valuable civics lessons, they should have presented a counter asseinbly, made an announcement, or modified regularly scheduled social-studies classes to discuss the merits of Fraser's speech and his candidate's legitimacy. Good teachers would have used the opportunity of Fraser's speech, known ainong teachers as a "teachable moment," to grab their students' interest and transfer it to the curricular lesson at hand, brcathing some life into the history books.

Finally, a majority of the Court revealed its lack of understanding of the fundamental principles of education, cognitive reasoning, and democratic discourse by omitting the text of Fraser's speech from its opinion. But for its inclnsion by Justicc Brennan in his concurrence, there would have been no way for readers to judge for themselves the accuracy of the Court's claims as to its offensive quality. Far more fundamental to democratic values than pretensions of civility is the need for freedom of information so that discerning people can make up their own minds on the merits of issues. It appears from the Court's presentation of the material in this case that it favors the inculeation approach not only for high school students but for readers of Supreme Court opinions as well.

323. Student and teacher personal intercommunication that is not connected with the school's work or mission is protected under Tinker, 393 U.S. at 512, and Hazelwood School Dist. v. Kuhlmeier, 484 U.S. 260, $270-71$ (1988).

324. See supra notes 107-09 and accompanying text (distinguishing speech that interccpts the school's curricnlar message from speech that contradicts the message).

325. See Kuhlmeier, 484 U.S. at 271. For an explanation of the theory that the Kuhlmeier limit on expression applies only to government expression, see Yudof, supra note 97, at 692-97.

326. See Burch v. Barker, 861 F.2d 1149 (9th Cir. 1988). In Burch the high school principal censured students for distributing copies of their privately produced, four-page newspaper at a senior-class picnic on school grounds without submitting it for predistribution review as required by school rules. The paper contained articles "generally critical of school administration policies concerning student activities .... [It] also included a mock teacher evaluation poll .... The paper did not include any profanity, religious epithets or any material which could be considered obseene, defamatory or commercial." Id. at $\mathbf{1 1 5 0}$. The only apparent harm was that "a few teachers who had been mocked in the newspaper became emotionally upset, but the distribution caused no violence or physical damage, nor did it interfere with classes." Id. at 1151 . Moreover, "[t]here was ... no evidencc that anyone familiar with [the paper] confused it with any school-sponsorcd publication or believed its contents reflected the view of the school administration." Id. at 1152. 
not materially or substantially interfere with or disrupt the work of the school or violate the rights or otherwise harm any meinbers of the school community. ${ }^{327}$ In evaluating speech under this third condition, the courts should consider factors such as the grade level and age of students affected by the speech. These three conditions permit a great deal of student expression that is fundamentally important to education, while allowing schools to suppress speech when it is necessary for the schools to impart their lessons to the student body at large.

\section{The Appeal of Thomas F. O'Connor: A Case Study}

The point at which curriculum-related student speech in the classroom and teacher response to such speech may be considered schoolsponsored was recently addressed by the New York State Commissioner of Education in the case of Thomas F. O'Connor v. Brentwood Union Free School District. ${ }^{328}$ O'Connor was a high school social-studies teacher in charge of a course entitled "Participation in Government," the primary goal of which was to develop students' civic competence by engaging them in public-policy debates of relevant local issues. ${ }^{329}$ He conducted a

That the paper was distributed in connection with a school-sponsored activity on school grounds was found insufficient to render it "school-sponsored" under Kuhlmeier. In addition, there were no more than "undifferentiated fears of possible disturbances or embarrassment to school officials," id. at 1159 , so the showing required to remove the paper from the protection of Tinker was not met.

327. See Tinker v. Des Moines Indep. Community School Dist., 393 U.S. 503, 508-09 (1968).

328. O'Connor v. Brentwood Union Free School Dist., No. 12219 (Sept. 8, 1989) (appeal to the Commissioner of Education, University of the State of New York, State Education Department, from action of the Board of Education of the Brentwood Union Free School District). The subsequent court appeal was dismissed in an opinion unpublished as of the date of this Article. See O'Connor v. Sobol, RJI 01-90-ST2435 (N.Y. Sup. Ct. Mar. 9, 1990). This dismissal has been appealed. O'Connor v. Sobol, No. 63880 (N.Y. App. Div. 3d Dept. argued Nov. 20, 1991).

329. See N.Y.S. Participation In Government Syllabus, supra note 301. "Participation in Government" is a required twelfth-grade social-studies course in New York. See id. at 19. The focus of the course is for high school seniors to develop their capacity to participate effectively as citizens by utilizing their acquired social-studies skills. Id. at 25 . The course syllabus discusses its goals at length using conceptual-development terms; the goals are essentially the development of students' skills in the gathering, evaluation, and expression of ideas relating to real-life civic questions and problems. Id. at 7-18. The syllabus emphasizes development of an inquiring, analytical student mind capable of exercising independent judgment. This goal is to be accomplished in large measure through the students' independent work and research, utilizing such skills as the location of information and evaluation of sources, allowing students who have located a possible source and noted its content to decide on its value for their purposes based on appropriate standards. Id. at 10, 29-30.

Neither the teachers nor students are expected to conform to any preconceived notions of socially proper values and norms. The teacher is the "facilitator rather than the source of information," developing evaluative procedures for activities that "emphasize[] student growth rather than achievement of a predetermined norm." Id. at 29 . The syllabus also contemplates nonconforming work by students:

In addition, this approach should result in students having the opportunity to examine and clarify their own positions and values and those of others, to formulate arguments to support or defend their positions, to express their positions in discussion of the issues, to 
classroom debate on the censorship of school library materials ${ }^{\mathbf{3 3 0}}$ and encouraged his students to conduct research on their chosen topics. One student on the procensorship side found a magazine article in the junior high school library entitled Better Orgasms, ${ }^{331}$ which she intended to use to support her position in favor of hibrary censorship. Prior to the debate she showed this article to O'Connor, who reviewed it and found it educationally appropriate. ${ }^{332}$ Following the debate, in which Better Orgasms was mentioned, O'Connor had a student photocopy the article and distributed it to the class for the students' possible reference in their assigned essays evaluating the merits of the debate.

After learning of the use of the Better Orgasms article in O'Connor's class and "beheving the article to be inappropriate for distribution to [O'Connor's] class of high school seniors," 333 school authorities met with O'Connor. ${ }^{334}$ The authorities advanced no reasons justifying either their assessment of the article or their condemnation of O'Connor's use of it. $^{335}$ Before reaching the merits of the matter, however, the discussion

listen to arguments and positions of others, to evaluate different values and positions, and

to work cooperatively with others in the search for alternative resolutions of the issues.

Id. at 29-30. Moreover, the syllabus explicitly recognizes that in this examination of public issues, controversial matters will and ought to be discussed. Suggested topics include divorce, censorship of texts and student publications, prayer in public schools, sale of sexually explicit materials, funding for abortion, legalization of marijuana, population control, and civil liberties. Id. at 26-28. The syllabus acknowledges that "Participation in Government poses a challenge to the school administration and the local community [byl ... risking the possibility that students may pursue issues that may be sensitive." Id. at 30 .

330. O'Connor, No. 12219, at 1-2.

331. Burns, Better Orgasms, EsSENCE, Oct. 1988, at 17-18.

332. See O'Connor, No. 12219, at 1-2 ("[p]etitioner alleges that he reviewed the article, determined that it was suitable for use in the debate, and permitted the article to be copicd and distributcd to the class"); see also Hentoff, A Teacher Bumps Up Against 'Controversy,' Wash. Post, Oct. 21, 1989, at A25, col. 4 (characterizing Better Orgasms as educationally suitable as a clinical text based on interviews with experts, and stating that the article emphasized the need for male sensitivity to the subject of female orgasms).

333. O'Connor v. Sobol, RJI 01-90-ST2435, at 2 (N.Y. Sup. Ct. Mar. 9, 1990). The original copy of the article was left on a photocopy machine, where it was discovered by a school secretary who brought it to the vice-principal, who then confronted O'Connor. See Hentoff, supra note 332.

334. O'Connor met twice with school officials. On November 29, he met briefly with Mr.' O'Brien, Assistant Principal, and Mr. McCarthy, Department Head of Social Studies. On November 30, he met with Mr. Gary Mintz, Associate Principal, and Mr. O’Brien, and brought his attorney, Mr. Mitchell Gittin, president of the local chapter of the American Civil Liberties Union, as well as Mr. Joseph Hogan, President of the Brentwood Teachers Association, and Ms. Edith Filosa, Chief Delegate of the Sonderling Center, the school where O'Connor taught. See Letter from Gary Mintz, Associate Principal, Sonderling Center, to Thomas O'Connor (Dec. 7, 1988) (on file with author) [hereinafter Letter from Gary Mintz].

335. There are fewer grounds for finding O'Connor's use of the Better Orgasms article inappropriate than in either of the precedential cases relied upon for that proposition. See Bethel School Dist. No. 403 v. Fraser, 478 U.S. 675, 678 (1986) (school authorities asserted that Fraser's comments were lewd, disrupted school discipline, taught uncivil lessons, and harmed the sensitivities of some of the audience); Hazelwood School Dist. v. Kuhlmeicr, 484 U.S. 260, 263 (1988) (principal asserted that student-written articles for school-sponsored newspaper did not mect journalistic 
broke down on whether the proceeding was disciplinary in nature. ${ }^{336}$ O'Connor was not given the chance to thoroughly explain or justify his objectives and methodology for his use of the Better Orgasms article in the classroom. ${ }^{337}$ Nevertheless, the school authorities later notified him that he "had demonstrated 'poor judgment' in choosing to use the ... article without first notifying the building administrators." ${ }^{338} \mathrm{He}$ was also issued three directives:

1) to review carefully any and all materials to be distributed to [his] students, understanding that [he would be] responsible and accountable for all materials distributed by [him].

2) to notify [his] Department Head ... of the dissemination of any material likely to be considered controversial by staff, class, or community. plans. $^{339}$

3) to submit in advance, in a timely fashion, complete lesson

This letter became part of O'Connor's permanent personnel file. ${ }^{340}$

O'Connor's appeal to the State Commissioner of Education was disinissed. ${ }^{341}$ The Cominissioner implicitly determined that the use of Better Orgasms in O'Connor's classroom constituted a curricular matter that the school had the power to regulate. ${ }^{342}$ The Commissioner then found the school authorities' directives to O'Connor to be an appropriate

standards in that one article did not convey the whole story and the other may have violated the anonymity of its subjects).

336. See O'Connor, RJI 01-90-ST2435, at 2 ("the discussion was abandoned when the petitioner, his representatives and school administrators could not agree as to whether the discussion was disciplinary in nature"); see also Letter from Thomas O'Connor to Gary Mintz, Associate Principal, Sonderling Center (Dec. 14, 1988) (copy on file with the author).

337. See Letter from Gary Mintz, supra note 334.

338. O'Connor v. Brentwood Union Free School Dist., No. 12219, at 2 (Sept. 8, 1989) (appeal to the Commissioner of Education, University of the State of New York, State Education Department, from action of the Board of Education of the Brentwood Union Free School District); see also O'Connor, RJI 01-90-ST2435, at 1-2. The associate principal's letter stated:

On Noveniber 29th, you distributed to your class an article entitled "Better Orgasms." You did so, by your own admission to me, after only skimming the article. In addition, at the November 29, 1988 mecting, you stated to Messrs. O'Brien and McCarthy that you did not think it was your responsibility to monitor the content of materials being distributed in your classroom. This, coupled with your decision not to inforn the building administration which might have to deal with the impact of such an article, demonstrates to me a lack of sound judgment. Your failure to submit, in advance, lessons [sic] plans detailing this lesson, further compounds ny concerns. Your poor judgment regarding these issues and lack of communication related to this article cannot go unnoticed.

Letter from Gary Mintz, supra note 334.

339. Letter from Gary Mintz, supra note 334.

340. O'Connor, RJI 01-90-ST2435, at 3.

341. O'Connor, No. 12219 , at 5.

342. Although finding that the school authorities had properly acted within their legal authority in regulating the use of the Better Orgasms article, the Commissioner did not specifically discuss how O'Connor's use of the article was a curricular matter or directly conclude that it was curricular. Id. at 3-4. 
"exercise of the district's discretion to regulate instructional content." Despite the school's power to review instructional materials, the Commissioner noted that "[school] administrators may only prevent the dissemination of material which is inappropriate to children of a particular age or maturity, or material that is otherwise lacking in educational value." 344 However, the Commissioner failed to show that Better Orgasms fell into either of those two excludable categories of expression. Rather, the Commissioner seemed influenced by the fact that the school authorities were not "motivated by an intention to advance a particular idea or ideology, or to deny access to an unpopular idea." 345

In dismissing O'Connor's appeal of the Commissioner's decision, the reviewing court narrowed the Commissioner's ruling to two basic issues. First, the court characterized the school authorities' directives as pertaining only to O'Connor's distribution of curricular materials and found that O'Connor's distribution of Better Orgasms was a curricular matter: "[T]he photocopying of the article and distribution to the entire class . . . is clearly the equivalent of a supplemental reading list and is subject to the control of the school board and its administrators." ${ }^{346} \mathrm{Sec}$ ond, by characterizing the letter from the school authorities as an "administrative evaluation" subject to collective bargaining rather than as a "disciplinary reprimand" invoking the procedural safeguards of the education law under which the action had been brought, the court avoided analyzing the validity of the letter's criticism of O'Connor. ${ }^{347}$

The most troubling aspect of this case is that the school authorities were not held to any standard of accountability for their determination of the educational mappropriateness of O'Connor's actions. O'Connor had complied with state-established curricular guidelimes, and the school failed to demonstrate any impropriety. If the expression related to the Better Orgasms article had been relegated to the categories of personal intercommunication among the students or speech otherwise unassociated with the school's curriculum, the issue would have been properly decided under the Tinker standard rather than under Fraser or Kuhlmeier. ${ }^{348}$ Under Tinker, which requires a showing of either a material or substantial disruption of the school's work or harm to students, it

343. The Commissioner cited to Hazelwood School District v. Kuhlmeier, 484 U.S. 260 (1988), and Bethel School District No. 403 v. Fraser, 478 U.S. 675 (1986), in making his decision. See C'Connor, No. 12219, at 4.

344. Id.

345. Id.

346. O'Connor v. Sobol, RJI 01-90-ST2435, at 4 (N.Y. Sup. Ct. Mar. 9, 1990). At the same time, however, the court believed that "the mere reference to the article or its use by a student in a debate would not constitute curriculum." Id.

347. Id. at 6-7.

348. See supra text accompanying notes 21-110 (discussing the Tinker and Fraser/Kuhlmeier standards). 
is unlikely that $\mathrm{O}^{\prime}$ Connor's actions would be considered inappropriate given his adherence to the state-endorsed curriculum and the clinical style of the article. However, Fraser and Kuhlmeier, and the inculcative model of education to which they both subscribe, allow school officials to suppress speech that does not conform to their curricular viewpoints using a construction of "curriculum" so broad as to include classroom speech in response to a school assignment. Consistent with this expansive view, school authorities were able to censure O'Connor's utilization of the Better Orgasms article without the showings required by Tinker. ${ }^{349}$ Thus, the deference to school authorities resulted directly from both the Commissioner's and the court's adoption of the Fraser/Kuhlmeier formulation. O'Connor's distribution of the article was interpreted as a curricular act of the school, rather than as incidental or as a response to student speech properly within the appropriate educational function of a classroom teacher. Because the article was "curricular," the school authorities had the discretion to control its use.

According to the understanding of education as conceptual development, O'Connor's photocopying and distribution of Better Orgasms to his students should not be seen as the school's endorsement of its content. ${ }^{350}$ Rather, O'Connor was appropriately responding to ideas that, although related to an assignment, originated with the students. O'Connor was properly fostering his students' conceptual development: he was helping them develop the knowledge and skills the school's curriculuin intended by referencing his students to their own ideas. As the conceptual-development process recogirizes, the objectives and inethods of teaching may be school-sponsored, but the particular building blocks that the students bring to the process are their own.

Despite the school authorities' view to the contrary, ${ }^{351}$ both the Better Orgasms article and O'Connor's use of it were educationally appropriate for the high school seniors in the "Participation in Government" course. O'Connor's decision to permit the student to introduce the article in support of her position in the debate ${ }^{352}$ was entirely consis-

349. See supra notes 98-103 and accompanying text (discussing the expansive deference to school authorities under Fraser and Kuhlmeier).

350. See Burch v. Barker, 861 F.2d 1149, 1158 (9th Cir. 1988) (recognizing that distribution of an article on school grounds was not synonymous with school endorsement). For a discussion of Burch, see supra note 326.

351. See supra text accompanying note 338.

352. The question of whether O'Connor had an obligation to present potentially controversial student debate materials, such as the Better Orgasms article, to school authorities as implied by their first directive to him, was not directly addressed by the Commissioner or court. The Commissioner found it significant that O'Connor "did not alert his supervisors to the fact that he would be using the [Better Orgasms] article in the classroom," O'Connor v. Brentwood Union Free School Dist., No. 12219, at 2 (Sept. 8, 1989) (appeal to the Commissioner of Education, University of the State of New York, State Education Department, from action of the Board of Education of the Brentwood Union Free School District), and the court also emphasized O'Connor's, not the student's, use of the 
tent with the state curricular guidelines for the course. ${ }^{353}$ The article advanced student discussion of public issues specifically recommended by the syllabus - censorship and the sale of sexually explicit inaterials. ${ }^{354}$ It provided data that students could appropriately use when evaluating these issues and coming to their own conclusions about them. ${ }^{355}$ The Better Orgasms article also conformed to the Brentwood Board of Education's own guidehines. ${ }^{356}$ Although the article was sexually explicit, O'Connor had reviewed the material and found it appropriate before distributing it to the class. ${ }^{357}$ Moreover, O'Connor, as classroom teacher, was in a position that enabled him to supervise any inappropriate or potentially harmful effects resulting from student comments. ${ }^{358}$ O'Connor's responsibility as teacher should not be to ignore or castigate student expression that may diverge from the school's curricular norms. Rather, he should serve as mediator with the divergent speech, to help it

article, O'Connor v. Sobol, RJI 01-90-ST2435, at 4 (N.Y. Sup. Ct. Mar. 9, 1990). These views may imply that once $O^{\prime}$ Connor approved the student's use of the article, he adopted it as part of his own classroom material, which school authorities can control as the school's message.

353. See supra note 329 (discussing the syllabus for the course).

354. See N.Y.S. PARTICIPATION IN GoverNMENT Syllabus, supra note 301, at 27.

355. A major activity of the course was participating in a statewide mock trial tournament for high schools. O'Connor, as coach for his school's mock trial team, legitimately could give his class mock trial problems that involved controversial issues. For example, the mock trial problem Barr $v$. $Z u f f$, used in the District of Columbia and various states, focused on AIDS and employment rights and involved detailed discussion of sexual practices. See Staff of the District of Columbia Street Law Project, Georgetown University Law Center, 1987 Strect Law Mock Trial Materials (on file with author); see also Oregon Law-Related Education Project, 1988 Oregon High School Mock Trial Competition (using Barr v. Zuff) (on file with author). In addition, the Law, Youth and Citizenship Project of the New York State Bar Association and State Department of Education adapted and used in 1990, as the problem for its annual statewide mock trial competition in high schools throughout the state, a trial developed by the D.C. Street Law Project in 1989 entitled Roberts $v$. D.C. The subject of the trial was sexual harassment, and the trial materials included reports of statements with sexual innuendo. See Law, Youth \& Citizenship Program, New York State's 1990 Statewide Mock Trial Tournament Materials (on file with author); Staff of the District of Columbia Street Law Project, Georgetown University Law Center, Official 1989 Mock Trial Materials (on file with author). The school administration's statement that O'Connor's distribution of the Better Orgasms article was "poor judgment" cannot be sustained as reasonable in light of the subject matter of these mock trials.

356. The Brentwood Board of Education's selection policy for basic instructional materials addressing the issue of sex is as follows:

While the use of profanity or frankness in dealing with sex may be deplored, such use in educational communications media does not automatically disqualify the materials. A decision for inclusion will be made on the basic [sic] of whether life is realistically presented and whether the material has asthetic [sic] or edueational value. Materials concerning dating advice and youth problems belong in school collections for young adults, as do scientific materials treating the reproductive process, when the information is presented in a factual, unsensational matter.

Brentwood Board of Education, Basic Instructional Materials: Selection Policy $\S(B)(8)$ (adopted Sept. 19, 1969) (on file with author).

357. See supra note 332 and accompanying text.

358. See supra notes 259-62 and accompanying text (describing mediating role of the teacher in the conceptual-development model). 
form a part of the school's larger mission. O'Connor's instruction did just that and was aimed at promoting his students' conceptual development. Such instruction, however, requires substantial tolerance by school authorities; their proper educational role should have been to support O'Connor rather than to criticize him.

Given the special significance of educationally appropriate student expression to a school program properly einploying conceptual development, school administrators should be required to meet Tinker's rigorous standard before suppressing student speech. ${ }^{359}$ Applying this standard to O'Connor's case, school authorities would first have had to articulate the school's mission with regard to the curricular goal of the "Participation in Goverument" course. That goal was to develop student skills in the analysis and assessment of controversial public-policy matters, encouraging students in their research and detailed exploration of the relevant facts and issues. ${ }^{360}$ Second, the admimistrators should have either demonstrated how O'Connor's class and assignment were incompatible with the school's mission or specified how the Better Orgasms article was otherwise inappropriate. ${ }^{361}$ In this case, the school authorities would have found this second condition of the Tinker standard difficult to satisfy. O'Connor was acting pursuant to the state's announced curricular goals. In addition, the langnage of the article was clinical rather than obscene. Moreover, the school received no student or parental complaints about the assignment. To improve the teaching profession, school administrators should only make criticisms they can justify by demonstrating the inappropriateness of teachers' actions. Teachers can then correct their errors and momitor their future performance in hight of the criticisms. Such showings are not unduly burdensome for the school, and without them teachers have no clear standard to guide their future conduct and are subject to seemingly arbitrary decisions by school authorities. ${ }^{362}$

The Fraser/Kuhlmeier standard was inappropriately used in O'Connor's case to judge the school authorities' criticism of the Better

359. See Tinker v. Des Moines Indep. Community School Dist., 393 U.S. 503, 511 (1969) (requiring substantial interference with schools' work before speech can be restricted).

360. See supra note 329.

361. The court to which O'Connor appealed from the Commissioner's decision apparently felt that O'Connor had the responsibility to reconcile the expressive interests of the students with the school's curricular goals. The court noted that "[O'Connor] failed to avail himself of two opportunities to explain why the article was distributed to his class. Due to such failure, [his] associate principal sent him a letter which . . . criticized [O'Connor's] exercise of judgment . . . ." O'Connor v. Sobol, RII 01-90-ST2435, at 2 (N.Y. Sup. Ct. Mar. 9, 1990).

362. The conceptual-development model recognizes the role of teachers in promoting students' development through supervision of student speech. Teacher speech rights are beyond the scope of this Article, but it should be obvious that teachers must enjoy at least the same rights as students for conceptual development to succeed. See generally Nahmod, First Amendment Protection for Learning and Teaching: The Scope of Judicial Review, 18 WAYNE L. REV, 1479, 1492-1514 (1972). 
Orgasms article. Fraser and Kuhlmeier incorrectly lead to the conclusion that student speech should be classified as either curricular or interpersonal commumication, ${ }^{363}$ a directive that led both the Commissioner and the court to characterize O'Connor's use of the article as curricular in nature. On the surface, O'Connor's distribution of Better Orgasms as part of an assignment appeared to signify his endorsement of the article, thereby mdicating school sponsorship of the article under agency theory. However, a deeper understanding of the work of the schools in terms of conceptual developinent, and O'Connor's contribution to this work, leads to a different conclusion. O'Connor, and the school, did not sponsor the viewpoint of the article. Rather, the article was part of an original student project, employed to aid in the development of students' critical thinking and rational deliberation, two objectives wholly in hine with the state-estabhished curriculum and the primciples of democratic education.

The real conflict in the O'Connor matter involved the question of who should determine the appropriateness of materials and ideas used in the classroom. School officials based their authority to make these determinations on their position of power in the bureaucratic hierarchy rather than on any objective educational judgment. The school officials prevailed not because they had an arguably persuasive educational reason for suppressing the Better Orgasms article-in fact, they articulated no grounds of any sort for their objection to the article-but merely because they were the desiguated school officials. O'Connor lost not because his actions were educationally inappropriate-in fact, they were appropriate by the school board's and state's own standards-but rather because school authorities were not held to their own standards, even in such an important inatter as classroom expression. In order to preserve effective conceptual developinent and advance students' cognitive capacities, however, student expression in the classroom must be protected from school authorities' unjustified determinations of its inappropriateness.

\section{CONCLUSION}

The prevailing Suprene Court understanding of the educational mission of the schools as inculcation fails to adequately take into account the value of student speech in school settings. This judicial view has resulted in first amendinent standards that have substantially diminished the protection of student speech. These standards and the educational practices that they support, however, disserve a central purpose of public education-that of preparing young people for democratic civic participation.

363. See supra notes 65-110 and accompanying text (discussing Fraser and Kuhlmeier). 
I have argued that the work of the schools should be understood as conceptual development rather than as inculcation of values. An inculcative description of the work of the schools is so imcomplete that it is inaccurate and misleading. On the other hand, the model of conceptual development, accepted by researchers in education and cognitive science, accurately conveys the true goals of the educational process as espoused by educators and approved by courts. In addition, inculcative educational practices in contravention of the schools' avowed objectives can be attributed to educationally inappropriate considerations, such as control over students, capitulation to parents and community members, lack of educational competence, and disguised viewpoint discrimination. These inculcative practices undermine the fundamental goals of democratic education and mask the deeper considerations at work im both the educational and democratic process.

Coguitive theory and research teach us that learners acquire knowledge and intellectual skills through an active process in which they construct, rather than receive, their knowledge and skills. Students construct their knowledge by exercising their own coguitive faculties, assimilating and accommodating information, with the result being highly individual and personal sets of knowledge and intellectual skills. Expression is essential for students to progress in their cognition and conceptual development. Learning by this process is necessary to enable individuals to effectively exercise such skills as critical thinking and rational deliberation, which are essential to the exercise of civic responsibilities and individual rights, including free-speech rights.

Student expression in the classroom that falls between expression approved by the school and expression that the school can demonstrate to be substantially disruptive of the school's work or harmful to others is worthy of significant first amendinent protection. This category of expression is presently governed by the imculcative "reasonable relationship to legitimate pedagogical concerns" standard of Fraser and Kuhlmeier that grants schools broad authority to suppress speech. How-, ever, the conceptual-development model of education recognizes the educational value of this category of divergent speech, despite disapproval by the school. Educators should not restrict such student speech without showing that it interferes with the school's work.

To develop legal doctrine that better comports with and promotes educational goals, courts need to recognize that schools are in the business of developing students' cognitive capacities. Under the current legal standard, founded on the Fraser/Kuhlmeier inculcative notion of education, courts defer to school decisions to abridge student speech on the grounds of educational practices that may in reality be pretexts for the suppression of disapproved viewpoints. The courts, due to their avowed 
lack of experience in educational matters, will probably be reluctant to hold that the conceptual-development model of education is mandated by the first amendment. But the courts have already imposed the inculcative model of education on the schools without any constitutional basis at all.

The courts should take a fresh look at education. They will find that the conceptual-development model of education is consistent with and supportive of first amendment values and student attainment of civic competence and that they need to establish a new strategy for evaluating student-speech cases. First, courts should understand the work of the schools in cognitive rather than inculcative terms. Next, courts should examine with closer scrutiny the compatibility of schools' avowed educational objectives with the student speech that school authorities seek to suppress. Finally, courts should accord less weight to the prescriptive power of the schools and more weight to the value of student speech. ${ }^{364}$

The constitutional rules determining the limits of school curricular authority over student expression inevitably shape both the values to be learned by students and the processes under which these values are learned. ${ }^{365}$ The power of the law in American society is such that legal rules often attain normative force beyond their purely legal force. That is, the fact that the law says one can legally act in a certain manner does not mean that one should. In particular, the fact that the United States Supreme Court will broadly defer to school authorities' decisions on the appropriateness of student speech in matters of curriculum does not mean that educators should restrict student speech with which they disagree in form or content. Even if the courts do not come to understand the work of the schools under a conceptual-development theory and fail to establish protections for student expression consistent with this theory

364. The conceptual-development model undermines present assumptions in the balance between school curricular authority and student speech rights. It implies, first, that the prescriptive power of the schools need not be as weighty as previously understood because legitimate educational aims are attainable through less-prescriptive educational policies and because more-prescriptivc educational practices are detrimental to democratic educational objectives. Second, students have considerably greater capacity for meaningful thought than historically or presently ascribed to them by the Court, so that the value accorded to student speeeh rights should be increased. The exercise of student speeeh is highly valued by students themselves and is vital to the success of the work aspired to by the schools. The peril to educators for not giving proper consideration to the valuc of student speeeh is educational failure, because without an authentic effort on the part of schools to engage in a substantial degree of free inquiry, even as to the worth of the schools' own instruction, the schools' message becomes diminished in credibility and the schools' work becomes diminished in quality. The peril for courts for not giving proper consideration to the value of student speech is that students may learn to appreeiate the value of freedom of speech not by its exercise but by its absence.

365. See A. Meiklejohn, Free Speech and Its Relation to Self-Government 32 (1960) ("Other institutions may be more direct in their teaching infuence. But no other institution is more deeply decisive in its effect upon our understanding of ourselves and our government [than the Supreme Court]."). 
and democratic education, school authorities can nevertheless abide by standards that accommodate conceptual development and encourage education consistent with the exercise of free expression in a democracy.

An understanding of schooling in cognitive terms does not preclude inculcation. Rather, the school maintains both its socialization function and its power to prescribe the curriculum; even under conceptual-development theory, students still have to demonstrate that they have learned that George Washmgton was our first president. ${ }^{366}$ This Article looks beyond inculcative education, however, and maintains that student speech offering nondisruptive and noninjurious additions or alternatives to the school's preferred messages, such as a student comment that "George Washington owned slaves," should be tolerated by school authorities as consistent with the school's educational mission. Moreover, student speech that diverges from curricular norms should be encouraged to the extent that such speech contributes to cognitive progress in learning. Assessment of the relevance, worth, correctness, or any other qualities of speech and its relationship to the curriculum should be the function of the teacher in the classroom. ${ }^{367}$ The teacher who responds to a student's comment that "George Washington owned slaves" by developing her students' capacities to assess both the validity of that comment and Washington's presidency in light of it is teaching in a manner that ought to be applauded.

366. See supra notes 1-2 and accompanying text for a hypothetical school lesson involving George Washington.

367. The teacher's judgment in these matters is not independent or autonomous, of course. The teacher should be guided by state and local curricular standards and sound educational policies and practices. Guidelines for the teacher should be consistent with standards of due process, providing adequate notice to the teacher as to what is and is not acceptable. See, e.g., Keefe v. Geanakos, 418 F.2d 359, 362 (1st Cir. 1969) (school regulation requiring teachers to discourage student use of profanity might provide adequate notice that discussing an article that included profanity would be grounds for dismissal); Parducci v. Rutland, 316 F. Supp. 352, 356-57 (M.D. Ala. 1970) (dismissal of teacher for assigning "inappropriate" readings is a violation of due process when no standards to guide the teacher's reading selection existed); see also Nahmod, supra note 362, at 1495-99 (discussing Keefe and Parducci).

For an example of the view that schools should be required to provide students with a notice of acceptable conduct, see Bethel School Dist. No. 403 v. Fraser, 478 U.S. 675, 695 (1986) (Stevens, J., dissenting) (unambiguous warning ought to be required to forewarn students of the possibility of punishment for offensive speech). 
